UNIVERSIDADE DE SÃO PAULO

FACULDADE DE FILOSOFIA, LETRAS E CIÊNCIAS HUMANAS

DEPARTAMENTO DE LETRAS CLÁSSICAS E VERNÁCULAS

PROGRAMA DE PÓS-GRADUAÇÃO EM FILOLOGIA E LÍNGUA PORTUGUESA

HELENA DE OLIVEIRA

Edição semidiplomática e análise diacrítica de manuscritos do século XIX da administração geral dos Correios em São Paulo 


\author{
UNIVERSIDADE DE SÃO PAULO \\ FACULDADE DE FILOSOFIA, LETRAS E CIÊNCIAS HUMANAS \\ DEPARTAMENTO DE LETRAS CLÁSSICAS E VERNÁCULAS \\ PROGRAMA DE PÓS-GRADUAÇÃO EM FILOLOGIA E LÍNGUA PORTUGUESA
}

\title{
Edição semidiplomática e análise diacrítica de manuscritos do século XIX da administração geral dos Correios em São Paulo
}

Helena de Oliveira

Dissertação de mestrado apresentada à Área de Pós-Graduação em Filologia e Língua Portuguesa, do Departamento de Letras Clássicas e Vernáculas da Faculdade de Filosofia, Letras e Ciências Humanas da Universidade de São Paulo, para obtenção do título de Mestre em Letras.

Área de Concentração: Filologia e Língua Portuguesa

Orientador: Prof. Dr. Marcelo Módolo

SÃO PAULO

2010 
Nome: OLIVEIRA, Helena de

Título: Edição semidiplomática e análise diacrítica de manuscritos do século XIX da administração geral dos Correios em São Paulo

Dissertação apresentada à Faculdade de Filosofia, Letras e Ciências Humanas da Universidade de São Paulo para obtenção do título de Mestre em Letras.

Aprovado em:

Banca Examinadora

Prof. Dr. Marcelo Módolo

Instituição: Universidade de São Paulo

Julgamento:

Assinatura:

Prof. Dr. Manoel Mourivaldo Santiago Almeida

Instituição: Universidade de São Paulo

Julgamento:

Assinatura:

Prof ${ }^{\mathrm{a}}$. Dr ${ }^{\mathrm{a}}$.Olga Coelho

Instituição: Universidade de São Paulo

Julgamento:

Assinatura:

Suplentes

Prof $^{a}$ Dr $^{a}$. Marilza de Oliveira

Instituição: Universidade de São Paulo

Julgamento:

Assinatura:

Prof. Dr. Afranio Gonçalves Barbosa

Instituição: Universidade Federal do Rio de Janeiro

Julgamento:

Assinatura: 


\section{DEDICATÓRIA}

Aos meus pais, Valdete e Maria Aparecida, pelo carinho e dedicação de toda uma vida. 


\section{AGRADECIMENTOS}

Ao Professor Heitor Megale (in memoriam), pela oportunidade concedida; Ao Professor Marcelo Módolo, pelas valiosas informações e tão cuidadosa orientação;

Ao Professor Manoel Mourivaldo Santiago de Almeida, pelos primeiros contatos com a filologia;

Às Professoras Olga Coelho e Marilza de Oliveira, pelas sugestões de leitura e indicações bibliográficas que tanto me ajudaram na elaboração dos capítulos;

À Paula Fontes Guinatti e ao Luís Antonio Pereira Martins, por colaborarem com o andamento de minha pesquisa, e acima de tudo, concederem-me tão preciosas horas de dedicação;

À minha irmã, Raquel, pela leitura e sugestões que me ajudaram a elaborar o trabalho; À Marileide, pela amizade sincera e contribuição;

À Denise, da Seção de Filatelia dos Correios, pelo empréstimo de riquíssimo material; Aos funcionários do Arquivo do Estado de São Paulo, pelo auxílio prestativo; Ao Cristovam, simplesmente, por existir. 


\title{
RESUMO
}

O presente trabalho trará a edição semidiplomática de manuscritos do século XIX, da Administração Geral dos Correios em São Paulo. Seu objetivo é analisar os sinais diacríticos, em especial o diacrítico ('). Tendo em vista, a abordagem quase inexistente acerca do assunto, buscou-se relacionar a intensidade, duração e timbre das vogais e sílabas no latim clássico e vulgar com o emprego destes sinais nos documentos do XIX. O objetivo é contribuir com os estudos da filologia, linguística histórica e história social. A dissertação foi dividida em duas partes: a primeira parte descreve aspectos histórico-sociais da instituição e da sociedade da época, trazendo uma análise codicologica do material; a segunda parte consiste no levantamento paleográfico, com especial atenção aos sinais diacríticos, abordando estes e os sinais de pontuação, suas funções e emprego, a terceira parte constituirá a edição semidiplomática dos documentos.

Palavras-chave: Filologia, Linguística histórica, Paleografia, Fonologia, História Social.

\begin{abstract}
The present work bring the semidiplomatics edition of manuscripts of XIX century, of General Management of Post Office in Sao Paulo. Its objective is to analyzes diacritics signals, in special the ('). In view of, the almost inexistent boarding concerning the subject, searched to relate the intensity, duration and stress of the vowels and syllables in the vulgar and classic Latin with the job of these signals in documents of the XIX. The objective is to contribute with the studies of philology, historical linguistics and social history. The paper was divided in two parts: the first part describes social historics aspects of the institution and the society that period, bringing a codicological analysis of the material; the second part was based on dates obtained from paleographycal aspects specially the diacrítical signals dealing with pontuation signal and its functions; the third part constitute the semidiplomatics edition of documents.
\end{abstract}

Key-words: Philology, Historical Linguistics, Paleography, Phonology, Social History. 


\section{SUMÁRIO}

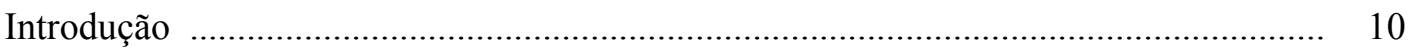

Primeira Parte - 1 Breve contextualização histórica....................................................... 13

1.1 Os Correios no Brasil colônia................................................................................. 13

1.2 Os Correios no Brasil império.............................................................................. 17

1.3 Os Correios em São Paulo..................................................................................... 19

1.3.1 São Paulo no século XIX e o sistema educacional................................................ 24

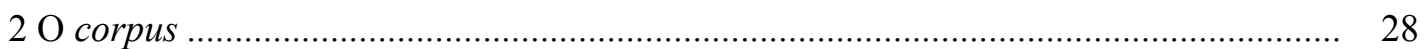

2.1 Descrição dos manuscritos analisados............................................................... 28

3 Aspectos codicológicos...................................................................................... 34

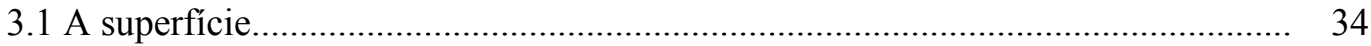

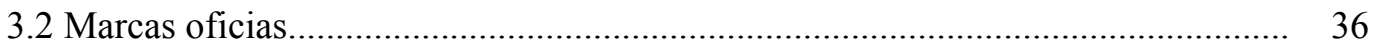

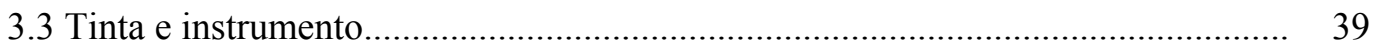

Segunda Parte - 4 Aspectos paleográficos.............................................................. $\quad 40$

4.1 Aplicação da paleografia nos documentos analisados......................................... 40

4.2 Os escribas e suas habilidades........................................................................... 43

4.2.1 Características da escrita: descrição dos aspectos encontrados em diferentes 43 punhos

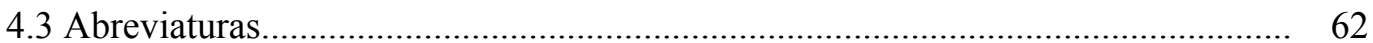

5 Pontuação e diacríticos: uma abordagem filológica..................................................... 66

5.1 Sinais de pontuação........................................................................................ 66

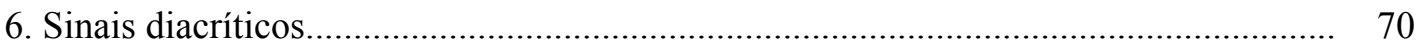

6.1 Apontamentos e definições....................................................................... 70

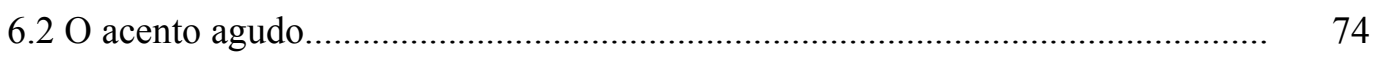

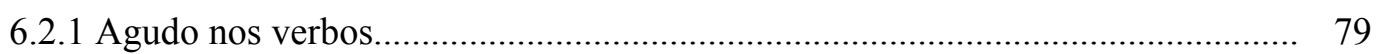

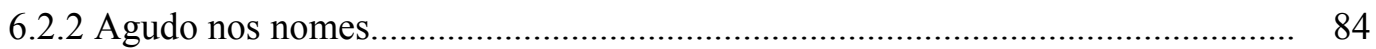

6.2.3 Agudo nos advérbios................................................................................... 87

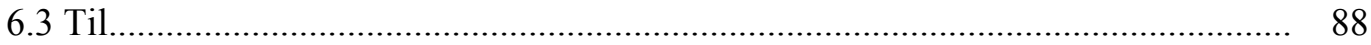

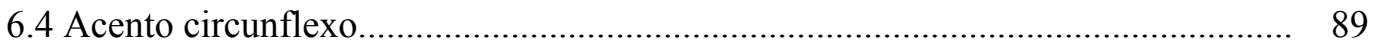

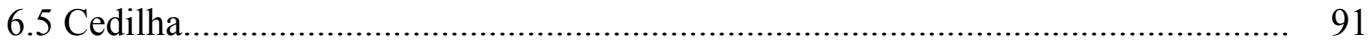

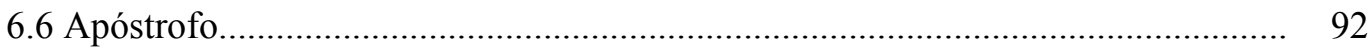

Terceira Parte - 7. Edição semidiplomática dos documentos da administração dos Correios.

7.1 Normas para a transcrição dos documentos........................................................ 94

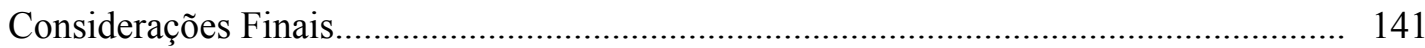

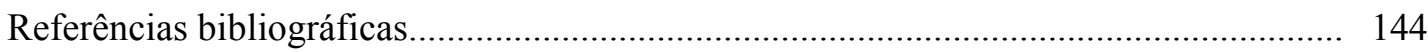




\section{LISTA DE FIGURAS}

Figura 01 - Mapa dos dais das saídas dos Correios................................................. 17

Figura 02 - Trecho do documento 08 com transcrição ........................................... 18

Figura 03 - Trecho do documento 02, das linhas 7 a 15, com transcrição................ 20

Figura 04 - Trecho do documento 03, das linhas 4 a 12, com transcrição.................... 21

Figura 05 - Excerto do documento 04, linhas 12 a 20, com transcrição.................... 21

Figura 06 - Trecho do documento 07, linhas 48 a 54, com transcrição....................... 22

Figura 07 - Trecho do documento 05, linhas 04 a 14, com transcrição...................... 23

Figura 08 - Parte do documento 08, linhas 20 a 23, com transcrição........................ 24

Figura 09 - Organograma da Administração dos Correios a partir do Decreto de

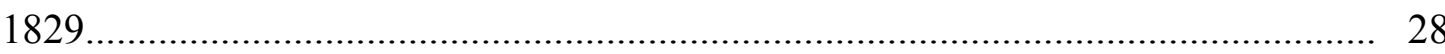

Figura 10 - Acondicionamento documental................................................... 35

Figura 11- Bordas das folhas........................................................................... 35

Figura 12 - Logotipo da Directoria Geral dos Correios......................................... 36

Figura 13 - Logotipo da Administração do Correio de São Paulo.............................. 36

Figura 14 - Logotipos da Administração dos Correios. À esquerda presente em documento de 1889 e à direita logo presente em documento de 37 1883.

Figura 15 - Timbre da Estrada de Ferro de Santos a Jundiahy................................ 37

Figura 16 - Timbre da Camara Municipal de São Manoel do Paraiso...................... 37

Figura 17 - Carimbo circular do Arquivo do Estado de São Paulo............................ 38

Figura 18 - Carimbo de Controle Interno.............................................................. 38

Figura 19- Exemplo de letra uncial em evocação - Documento 09, linha 13........... 41

Figura 20 - Exemplo de letra uncial em evocação - Documento 07, linha 13.......... 42

Figura $21-<\mathrm{F}>$ em início de frase - Documento 01, linha 01.............................. 42

Figura 22 - Prolongamento do grafema $<\mathrm{q}>$ em meio de palavra e $<\mathrm{p}>$ em início de palavra- Documento 10, linhas 07 e 20.......................................................... 42

Figura 23 - Doc. 10 - Prolongamento de $<\mathrm{A}>,<\mathrm{T}>$ e $<\mathrm{I}>$ em inícios de frase, no primeiro caso, e início de palavra em meio de frase nos dois últimos grafemas.

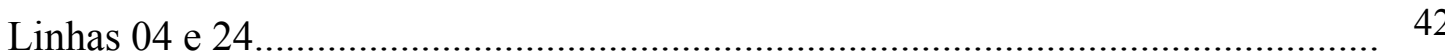

Figura 24 - Definição de Bluteau em Pontuação....................................................... 66

Figura 25- Definição de Moraes em vírgula......................................................................... 65 
Figura 26 - Definição de Moraes em hífen.............................................................. 68

Figura 27 - Definição de Acento em Bluteau.......................................................... 70

Figura 28 - Definição de Prosódia em Bluteau......................................................... 71

Figura 29 - Significado de A em Moraes........................................................... 73

Figura 30 - Significado de fórma.................................................................... 74

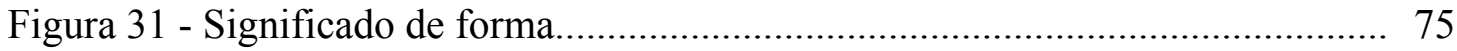

Figura 32 - Definição de Til em Bluteau................................................................ 87

Figura 33 - Definição de circunflexo em Moraes....................................................... 89

Figura 34 - Definição de Cedilha em Moraes.......................................................... 91

Figura 35 - Definição de apóstrofo em Bluteau.................................................... 92 


\section{LISTA DE TABELAS}

Tabela 01 - Relação dos documentos analisados. 31

Tabela 02 - Comparativo entre traçado textual e assinatura.................................... 44

Tabela 03 - Semelhança nos grafemas dos documentos 05, 06 e 08...................... 45

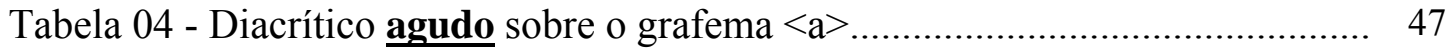

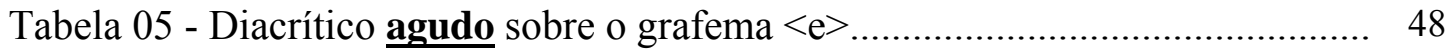

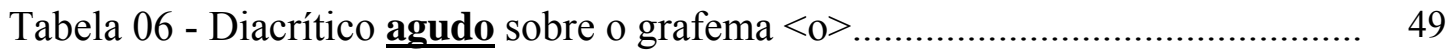

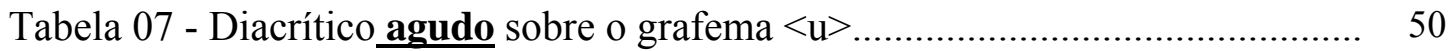

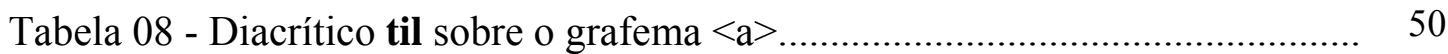

Tabela 09 - Diacrítico til sobre o grafema $<$ e $>$................................................ 52

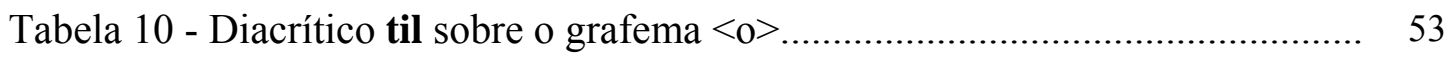

Tabela 11 - Diacrítico til sobre consoantes.......................................................... 55

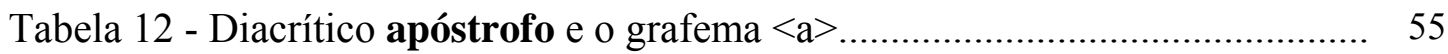

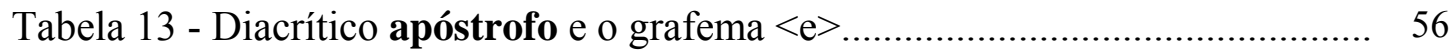

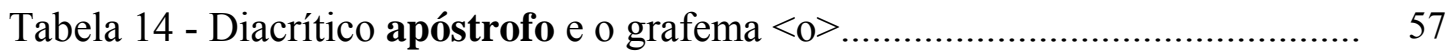

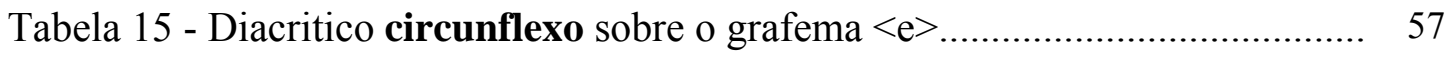

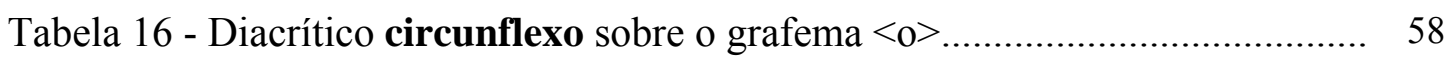

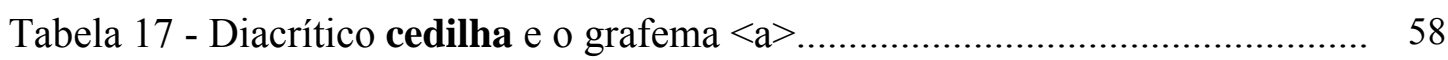

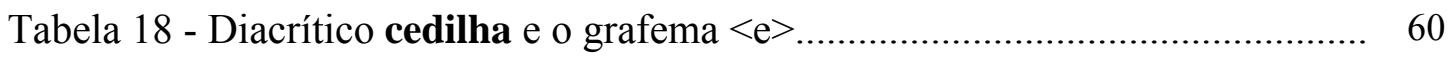

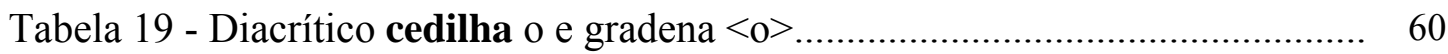

Tabela 20 - Mudança das vogais breves e longas para abertas e fechadas.............. 78

Tabela 21-Terminações dos verbos do latim e do português: $3^{\mathrm{a}}$ e $4^{\mathrm{a}}$

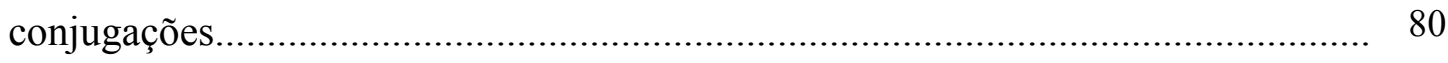

Tabela 22 - Vocábulos e etimologia............................................................... 89 


\section{Introdução}

O corpus do presente trabalho foi levantado no Arquivo do Estado de São Paulo, em consulta à lata 5641, fundo da Administração dos Correios. Composto por documentos avulsos, os manuscritos traçam as características da instituição, que se firmou sob uma administração centralizada no Brasil, a partir da chegada da família real à colônia.

Trata-se de documentos apógrafos, produzidos no decorrer do século XIX, cujos autores são funcionários alfabetizados e, pelo que demonstram os decretos que regiam a instituição no século XIX, teriam o conhecimento das línguas inglesa ou francesa. Esta conclusão pôde ser retirada do conteúdo presente em decretos específicos, os quais exigiam, para ocupação de determinados cargos, o conhecimento destes idiomas. Os cargos tinham funções diferenciadas dentro da instituição e estavam embasados em decretos e regimentos internos. O principal decreto, o qual nos apoiamos para a realização da pesquisa, e de certas conclusões, foi o decreto de março de 1829, primeiro documento que oficializou a centralização dos Correios no Brasil.

As assinaturas dos manuscritos pertencem aos administradores gerais dos Correios e a representantes de instituições ligadas ao funcionamento do serviço postal, dentre eles, as companhias de estrada de ferro, importantes meios de interligação e distribuição de correspondências, em meados do século XIX. Possivelmente, por este motivo tais cartas integrem o acervo de documentos dos Correios.

O corpus é composto de 10 manuscritos elaborados nos anos de 1833, 1868, 1879, 1881, 1883, 1889 e 1890. A periodização, centralizada no final do século XIX, deve-se ao conteúdo dos documentos e ao importante resgate histórico, mais facilmente realizado, com a análise dos manuscritos desse período, pois o objetivo do trabalho filológico não se centraliza, somente, na busca de traços antigos da língua, mas também se preocupa com a reconstituição histórica de uma época, neste caso, de uma instituição. Tal característica insere-se na função transcendente da filologia, que será abordada no primeiro capítulo, em que realizaremos o levantamento histórico dos dados presentes nos documentos, buscando nos hábitos socioculturais traços econômicos e históricos. Conforme Spina (1977, p, 77) a filologia divide-se em três funções: função substantiva, adjetiva e transcendente, a saber:

$\left.1^{a}\right)$ Função substantiva, em que ela se concentra no texto para explicá-lo, restituí-lo à sua forma genuína e prepará-lo tecnicamente para publicação. $2^{\mathrm{a}}$ ) Função adjetiva, em que ela deduz do texto, aquilo que não está nele: a determinação de autoria, a biografia do autor, a datação do texto, a sua posição na produção literária do autor e 
da época, bem como a sua avaliação estética (valorização). $3^{\mathrm{a}}$ ) Função transcendente, em que o texto deixa de ser um fim em si mesmo da tarefa filológica, para se transformar num instrumento que permite ao filólogo reconstituir a vida espiritual de um povo ou de uma comunidade em determinada época.

Sob a função substantiva buscamos aspectos linguísticos que pudessem mostrar-nos as relações existentes entre o uso dos diacríticos na escrita com as abordagens de gramáticos da época.

A dissertação foi dividida em três partes. Do primeiro ao terceiro capítulo está compreendida a primeira parte do trabalho, que tratará dos aspectos transcendentes da filologia. Buscamos também informações que comprovassem a escolaridade dos escribas e a veracidade dos dados contidos nos manuscritos. Para isso verificou-se legislações e decretos, que regiam os Correios em Portugal e no Brasil, no período em questão, bem como os processos educacionais em São Paulo, no século XIX.

A descrição detalhada do corpus será abordada no segundo capítulo. Nesse capítulo traçaremos uma relação entre o conteudo dos documentos e os respectivos autores. Classificaremos os documentos, de acordo com seu objetivo, considerando também os manuais e leis da época, que padronizavam os modos de escrita.

No capítulo três abordaremos os aspectos codicológicos do corpus, observando as marcas oficiais, carimbos e tintas empregados na marcação de seções pelos quais os documentos passaram o tipo de papel e o recipiente em que foram armazenados os documentos.

A segunda parte tem como objetivo a análise dos diacríticos, numa tentativa de buscar na herança etimológica a motivação para o emprego dos respectivos sinais no corpus. No quarto capítulo verificaremos os aspectos paleográficos de cada documento, relacionando-os às características gráficas na escrita dos diacríticos e a incidência de diferentes punhos e os tipos de abreviaturas. $\mathrm{O}$ estudo paleográfico versará sobre a feitura dos sinais diacríticos, tendo como objetivo eliminar possíveis dúvidas acerca da aposição e característica do sinal empregado. A descrição da semelhança e diferença possui dupla função: a primeira é identificar o traçado e semelhanças existentes entre os hábitos de escrita em comparação aos demais. A segunda função é reconstituir o modelo de funcionamento das instituições públicas, no século XIX, voltando à questão transcendente da filologia.

No quinto capítulo, abordaremos os sinais de pontuação presentes nos documentos, bem como seu emprego. No sexto capítulo, partiremos para a análise linguística, com o estudo dos sinais diacríticos do corpus. Centralizaremos nossos esforços na reconstituição 
etimológica dos vocábulos, com o objetivo de explicar a relação existente entre o emprego dos diacríticos, em especial o ('), e a duração das vogais no latim clássico e timbre do latim vulgar. Para tanto buscaremos em gramáticos do século XIX as relações existentes entre a prosódia e o acento gráfico. A partir disso e sob um enfoque fonológico, contemplaremos a intensidade, altura, duração e timbre das vogais e das sílabas, no latim clássico e vulgar buscando relações com o emprego dos sinais diacríticos no português do século XIX.

A terceira parte reserva-se ao sétimo capítulo, que trará a edição semidiplomática do corpus. Optamos por este tipo de edição para que os aspectos originais da língua da época fossem mantidos, servindo como base para estudos futuros que possam subsidiar o campo da filologia e da linguística histórica. 


\section{Breve contextualização histórica}

\subsection{Os Correios no Brasil Colônia}

Na colônia, a distribuição das cartas era atribuída ao correiomor, título dado por D. Manuel ao cidadão responsável pela recepção e entrega das cartas. Com a expansão marítima fazia-se necessário o aumento da comunicação, para estreitamento das relações comerciais. Foi assim, que a Coroa Portuguesa deu a Luiz Homem o cargo de correiomor, o primeiro em Portugal, posto que ocuparia até 1532.

O oficio de Correio-Mor do Reino e das Cartas do Mar, compreendia monopólio sobre todas as cartas que fossem e viessem para e de qualquer parte de fora de Portugal (ilhas, possessões, conquistas, etc), assim como as de outros países, além de explorar linhas de correios terrestre na Capitania e correio marítimo entre os portos do Brasil. (BARROS NETO, 2002, p. 23)

Após a morte de Luiz Homem, Luiz Afonso é eleito o segundo correiomor do reino, cargo que ocuparia até 1575. Com a morte de Luiz Afonso assume o ofício de terceiro correiomor, seu genro, Francisco Coelho. Com a morte deste e sem que Francisco Coelho tivesse tido filhos homens, o cargo deveria ser passado ao genro de Francisco, conforme disposto no Alvará de 10 de junho de 1576, e sendo assim, o cargo de quarto correiomor do Reino foi de Manoel de Gouvêa, marido de Inês Guerra, filha de Francisco Coelho. Com a morte de Manoel Gouvêa, em 1598, o reino passaria 08 anos sem um responsável pelo ofício e o rei decidiu vender o cargo a Luis Gómez da Matta. O ofício foi vendido por "sessenta mil cruzados" (ROSARIO, 1993, p. 19). Para vislumbramos o quanto equivalia o valor do oficio explanaremos um pouco sobre as moedas portuguesas, relacionando-as com as aquisições da época e seus respectivos valores. As moedas portuguesas, na época em questão, eram o cruzado e o real. O cruzado era uma moeda cunhada em ouro, com grande valor monetário. Já o real era uma moeda de fácil acesso e de maior utilização. O mesmo real também se denominava réis. Para melhor compreensão e estabelecimento de parâmetros entre ambos verificamos os valores de ambos e constatamos que um cruzado equivalia a quatrocentos reais ou réis. O salário médio de um pedreiro era um cruzado, de um escrivão oito cruzados, do 
governador geral Tomé de Souza, oitenta e três cruzados. O valor de uma nau portuguesa era dois mil e quinhentos cruzados. Diante destes números, podemos concluir que o valor do ofício de correiomor era uma quantia considerável. Por dois séculos o ofício de correiomor foi transmitido para os descendentes de Luiz Gomez da Matta.

Com a descoberta de novas terras, o ofício de correiomor não se estendia mais, somente, ao território português e, em 1663, Luiz Gomes da Matta nomeia para o cargo de correiomor da capitania do Rio de Janeiro o alferes João Cavaleiro Cardozo.

Em 13 de janeiro de 1735, é nomeado ao cargo de correiomor do reino e do mar, João de Azevedo Loureiro, para a Vila de Santos. Este correio serviria exclusivamente para a comunicação da vila de S. Paulo com o exterior, por meio do porto de Santos.

É com o governo de Morgado de Mateus, a partir do ano de 1765, que se questiona a ausência de uma linha de correio terrestre na vila de S. Paulo e o então governador requere a autorização para a utilização do serviço postal na vila, alegando a extrema necessidade de comunicação, pois estes "seriam muito úteis ao bem público tanto para facilidade dos negócios como para as Correspondências particulares" (Ofício de Morgado de Mateus apud BELLOTO, 2007, p. 205).

A correspondência oficial, destinada aos outros órgãos da coroa, era enviada por terra, por meio de soldados, como provavelmente ocorria com as cartas trocadas entre a administração dos Correios e o governo da província.

Mas em 1772, Morgado de Mateus ${ }^{1}$ estabelece o transporte de cartas entre a Vila de S. Paulo e a capital, no Rio de Janeiro, conforme carta de 11 de outubro de 1772 (apud BELLOTO, 2007, p. 206):

\footnotetext{
Porquanto he essencialmente necessário no serviço de Sua Magestade no tempo prezente que se estabeleção e se conservem paradas promptas a toda deligencia os avizos e ordens do Real Serviço desta cidade para a Capital do Rio de Janeiro: Ordeno a todos os Capitaens Mores que ficão na derrota do dito caminho que logo recebendo esta, na conformidade das Reaes Ordens, façao establecer nos Seos Destrictos paradas promptas, pelos moradores que se acharem na direcção do dito caminho que discorre de um para outro Governo, pelas quaes farão remeter instantaneamente todas as ordens e cartas do serviço que se enviarem de huma para outra Capital $[\ldots]$
}

Em 1796, Manuel José da Maternidade de Souza Coutinho da Matta assume como décimo primeiro correiomor do reino de Portugal e último, pois, com o rápido

\footnotetext{
${ }^{1}$ São Paulo, 11 de outubro de 1775. (DI 33, p. 75-6).
} 
desenvolvimento das relações mercantis e a necessária troca de informações, o serviço postal mostrava-se ineficiente e era necessário o estabelecimento de um contato mais rápido com Portugal, tendo em vista, o crescimento das relações comerciais.

Inicia-se o processo de organização e centralização do sistema postal, por meio do alvará de 20 de janeiro de 1798, que visava à constituição de uma administração de Correios na cidade do Rio de Janeiro. O alvará previa a existência de correios marítimos entre Portugal e Brasil, bem como o correio terrestre entre as vilas e as cidades brasileiras.

Para tanto foi criada a administração do Correio, na capital da colônia, a cidade do Rio de Janeiro. A partir de então se encarregou

\footnotetext{
a Repartição de Marinha de expedir, a cada dois meses, Paquetes Correios Marítimos pra o porto de Assu, servindo as Capitanias de Pernambuco, Paraíba, Maranhão, Piauí e Pará, indo às Salinas e retornando a Portugal. Os Paquetes transportavam, além de correspondências, pequenas encomendas e produtos do País, ficando sujeitos aos Regulamentos e despachos das alfândegas, sendo o frete regulado pela Administração do Correio-Geral de Lisboa. (ROSÁRIO, 1993, p. 37)
}

Em março do mesmo ano, foram criadas linhas postais entre a Vila de Sabará, Vila Rica, Vila de S. João Del Rey, Vila do Príncipe, Arraial do Paracatu e a capital, utilizando um estafeta e um escravo para realização do transporte das cartas. Estafetas, como o próprio significado da palavra remete, eram oficiais com montaria, responsáveis pelo transporte de correspondências. Cada trajeto tinha um tempo estimado para realização que variava entre 15 e 42 dias. Em trajetos mais longos, como o da vila do Sabará ao Arraial de Paracatu, cerca de 177 léguas de distância, ou, 842 quilômetros, era necessária a presença de dois soldados de cavalaria, para o revezamento da viagem.

É a partir do alvará de 1798 que a Vila de S. Paulo, sob o comando do capitão general Antonio Manoel de Mello Castro e Mendonça, também passa a realizar trajetos internos para a entrega das comunicações.

Em 1801 foram implantadas duas linhas postais, que tinham como destino as Vilas de Porto Feliz, Paranaguá e S. Vicente. Em transportes realizados entre os portos, cujos destinos eram outros países, as malas seguiriam seu caminho por meio de navio._Neste tipo de transporte eram utilizadas as fontes naturais das vilas e o rio Tietê era um destes meios. Outras vezes fazia-se uso das trilhas realizadas pelas bandeiras. Exemplo disso é a bandeira de Fernão Dias Pais que "acompanhou o curso do rio Tietê até a foz do rio Paraíba, descendo 
pela margem deste, passando pelas cidades de Jacareí, Taubaté, Pindamonhangaba chegando a Guaratinguetá e daí à Cachoeira” (PAULIS, 2000, p. 97 in Filologia Bandeirante).

O rio Tietê não era somente um roteiro de penetração, mas era também utilizado para navegação e transporte, pois

\begin{abstract}
Até início do século XIX esteve ativa, como via de penetração, quando começou a declinar, face às facilidades apresentadas pelos caminhos de terra, mais curtos e possibilitando o transporte de cargas em lombo de mulas bem como a mudança de rota, já com o advento da navegação. (RIBEIRO JUNIOR, 1995)
\end{abstract}

Com a chegada da família real, em 1808, os serviços de Correios passaram por grandes transformações e a estrutura adotada passou por adequações estruturais, como, por exemplo, o acréscimo de funcionários para a realização de entrega de correspondências entre as administrações e aos particulares. Entre as vilas, incrementou-se a implantação de trajetos terrestres, mas ainda havia a descentralização administrativa, pois, cada vila, que possuía linha postal, era responsável pela administração de suas respectivas.

Apesar da expansão das linhas, as cartas, ainda, eram transportadas por particulares e "a correspondência expedida para o interior de S. Paulo, por exemplo, era transportada por mensageiros, que eram pagos pelos interessados ou por graciosidade de viajantes ocasionais" (BARROS NETO, 2003, p.32). Tal característica apresentava-se como uma fragilidade estrutural, uma vez que o transporte de mensagens por particulares era proibido, conforme alvará de 1798. Fazendo-se cumprir as determinações do referido alvará em território paulista, o governador Antonio Manoel de Mello Castro reafirma:

prohibido e defeso á toda e qualquer pessoa particular, ou seja Viadante e Tropeiro, de terra, ou mestre Marinheiro e passageiros do mar, o levar Cartas e Massos ou Sacas de Cartas pelo logares onde se acha já estabelecido o Correio e para o futuro, por aquelles adonde se estabelecer com a comunicação das penas, impostas aos extraviadores dos Direitos Reaes (Carta de Antonio Manoel de Mello Castro e Mendonça ${ }^{2}$ apud ROSARIO, 1993, p. 46)

Com a vinda da família real, D. João VI introduziu todos os serviços de governo e administração na colônia. Estas providências culminaram na proclamação do primeiro

\footnotetext{
${ }^{2}$ Documento pertencente ao Arquivo do Estado de São Paulo, conforme informações do autor.
} 
regulamento postal do Brasil, instituído em 22 de novembro de 1808, denominado Regulamento Provisional para a Administração Geral do Correio da Corte.

Ainda assim, com a criação do Regulamento, não ocorreu a centralização das linhas de correios e estas permaneciam sob a responsabilidade da administração dentro das vilas das quais seguiam. Além do incremento das linhas a expedição das malas passou a ser realizadas em dias certos, como aponta o quadro abaixo.

\begin{tabular}{|c|c|c|c|c|c|c|c|c|c|c|c|}
\hline \multicolumn{12}{|c|}{$\begin{array}{c}\text { MAPPA } \\
\text { DOS DIAS DAS SAHIDAS DOS CORREIOS POR TERRA NO }\end{array}$} \\
\hline \multirow{2}{*}{$\begin{array}{l}\text { ANNO } \\
\text { DE } \\
1809 \\
\text { JANEIRO }\end{array}$} & \multicolumn{5}{|c|}{$\begin{array}{c}\text { PARA } \\
\text { MINAS } \\
\text { Todas as Terças feiras }\end{array}$} & \multicolumn{3}{|c|}{\begin{tabular}{|c|} 
PARA \\
CAMPOS \\
As Quartas feiras \\
de $15 \mathrm{~cm} 15$ dias \\
\end{tabular}} & \multicolumn{3}{|c|}{$\begin{array}{c}\text { PARA } \\
\text { S. PAULO } \\
\text { Aos Sabados } \\
\text { de } 15 \mathrm{em} 15 \text { dias }\end{array}$} \\
\hline & 3 & 10 & 17 & 24 & 31 & 4 & 18 & & 7 & 21 & \\
\hline FEVEREIRO & 7 & 14 & 21 & 28 & & 1 & 15 & & 4 & 18 & \\
\hline MARÇO & 7 & 14 & 21 & 28 & & 1 & 15 & 29 & 4 & 18 & \\
\hline ABRIL & 4 & 11 & 18 & 25 & & 12 & 26 & & 1 & 15 & 29 \\
\hline MAIO & 2 & 9 & 16 & 23 & 30 & 10 & 24 & & 13 & 27 & \\
\hline JUNHO & 6 & 13 & 20 & 27 & & 7 & 21 & & 10 & 24 & \\
\hline JULHO & 4 & 11 & 18 & 25 & & 5 & 19 & & 8 & 22 & \\
\hline AGOSTO & 1 & 8 & 15 & 22 & 29 & 2 & 16 & 30 & 5 & 19 & \\
\hline SETEMBRO & 5 & 12 & 19 & 26 & & 13 & 27 & & 2 & 16 & 30 \\
\hline OUTUBRO & 3 & 10 & 17 & 24 & 31 & 11 & 25 & & 14 & 28 & \\
\hline NOVEMBRO & 7 & 14 & 21 & 28 & & 8 & 22 & & 11 & 15 & \\
\hline DEZEMBRO & 5 & 12 & 19 & 26 & & 6 & 20 & & 9 & 2 & \\
\hline $\begin{array}{l}\text { HORAS } \\
\text { DAS } \\
\text { PARTIDAS }\end{array}$ & \multicolumn{5}{|c|}{$\left.\begin{array}{l}\text { De Verào ás } 6 \\
\text { De Inverno ás } 5\end{array}\right\}$ da tarde } & \multicolumn{3}{|c|}{$\begin{array}{l}\text { Effectivamente } \\
\text { ás } 10 \text { da manhẫ }\end{array}$} & \multicolumn{3}{|c|}{$\begin{array}{l}\text { Effectivamente } \\
\text { ás } 5 \text { da tarde }\end{array}$} \\
\hline
\end{tabular}

Fonte: Três Séculos e meio de história postal brasileira (1500-1843).

Figura 01 - Mapa dos dias das saídas dos Correios

\subsection{Os Correios no Brasil Império}

"Até 1824 havia na província de S. Paulo poucas linhas de correios terrestres e uma de correio marítimo". (ROSARIO, 1993, p. 68). Apesar do alvará de 1798, que proibia o transporte de cartas por terceiros a correspondência enviada ao interior da província era levada por interessados ou viajantes ocasionais. Para correspondências oficiais, como informava o Regulamento Provisional, "haverá um correio para entrega dos officios dirigidos às Secretarias de Estado e Tribunaes, e para a entrega das cartas retardadas na Administração do Correio aos Particulares, o qual terá o cuidado no aceio". (ROSARIO, 1993, p. 56). Neste trecho, compreende-se por correio, o homem responsável pela entrega da correspondência.

Com a independência do país, fez-se necessária a unificação e centralização de todas as linhas postais criadas até aquele momento e, para tanto, foi criado o Decreto de 05 de 
março de 1829, que instituiu o Regulamento da Administração Geral dos Correios no Brasil. Criou-se com o novo decreto, a administração geral dos Correios no Brasil, sob a jurisdição de uma administração geral.

Este novo órgão tinha como finalidade fiscalizar, dirigir e promover a melhoria das práticas vigentes em todas as linhas postais do país e futuras agências que se criariam, além de controlar a gestão econômica e financeira das administrações gerais dos correios provinciais. Sua sede era no Rio de Janeiro, a capital do Reino.

Ficou estabelecido também que em cada província haveria um Administrador, chefe de todas as agências de correios. Ele seria auxiliado por oficiais, em número necessário para a execução dos serviços postais. Seria também o responsável pelo controle econômico, financeiro e operacional de todos os correios da província, como rege o artigo $3^{\circ}$, capítulo II do decreto de 5 de março de 1829:

Pertence ao seu officio, e responsabilidade a fiscalização da receita e despeza, e o governo econômico da administração do correio geral desta Corte e Província; fazer com que todos os empregados cumpram exactamente os seus deveres

Podemos confirmar tal regra ao verificarmos documento 08, linhas 08 a 13, p. 127, em que a administração geral dos Correios de São Paulo informa sobre o comportamento de um correio ambulante, sugerindo a não concessão de licença, como segue:

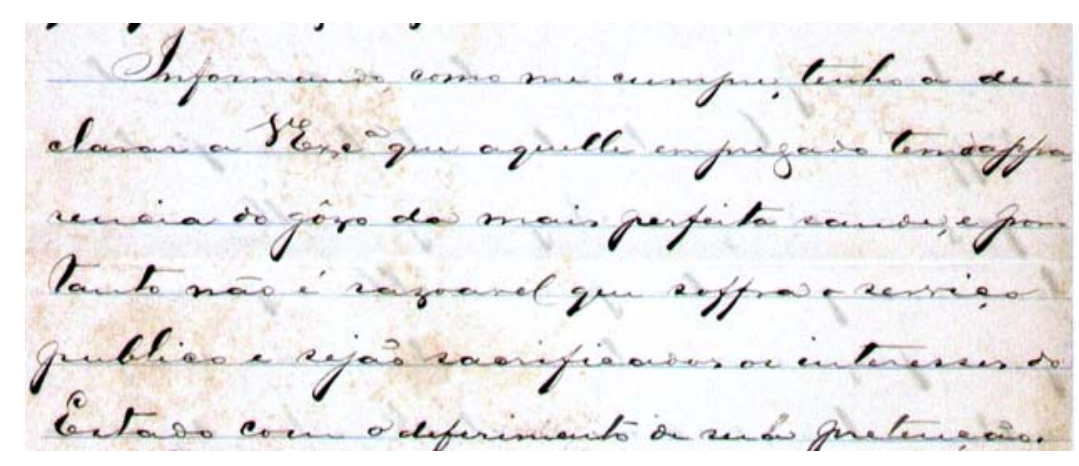

Informamos, como me cumpre, tenha a declarar a Vossa Excelência que aquelle empregado tem a appa rencia do gôzo da mais perfeita saude, e portanto não é razoável que soffra o serviço publico e sejaõ sacrificados os interesses do Estado com o deferimento de sua pretensão.

Figura 02 - Trecho do documento 08 com transcrição 
Também foi definido que todas as cidades e vilas deveriam possuir, obrigatoriamente, um agente de correios, conforme artigo 21, cap. III, do mesmo decreto:

Nas capitaes das Províncias haverá hum Administrador de todos os Correios das mesmas com hum Ajudante, e os mais officiaes que forem necessários, arbítrio do Director Geral sobre proposta do respectivo Administrador.

Embora a administração dos Correios na província fosse subordinada à diretoria geral dos Correios no Rio de Janeiro, as questões que envolvessem deliberações quanto a gastos e prestações de contas locais eram informadas ao presidente da província. Ele deliberaria por si ou enviaria a solicitação à Administração Geral dos Correios, na Corte, pois a partir de 1860 os Correios passaram à subordinação da Secretaria de Agricultura e Vias Públicas, fazendo com que todos os documentos, obri gatoriamente, tivessem o aval do presidente de província. Além disso, era atribuição do presidente da província:

estabelecidas pelo artigo da lei de três de outubro de 1834 [...] cabendo aos mesmos executar e fazer executar as leis, dispor de força pública e, principalmente, atuar junto à questão dos empregos públicos, tanto àqueles que a lei lhe facultava quanto, de forma provisória, os que cabiam ao imperador. (CABRAL, 2009, p. 53)

É devido a isso que encontramos, em grande parte do corpus, o endereçamento ao presidente da província. Ainda que, todas as situações referentes aos funcionários e agências de Correios fossem centralizadas na Administração Geral de São Paulo o posicionamento final deveria partir do presidente da província. Esse procedimento não descaracterizava as definições do Decreto de Março de 1829, pois se tratava de praxe administrativa, prevista, inclusive, no próprio Decreto.

\subsection{Os Correios em São Paulo}

Como verificado anteriormente, as primeiras rotas de correios passaram a ocorrer em terras paulistas, no século XVIII, sob o governo de Morgado de Mateus. No século XIX, a regularidade das linhas postais deu-se a partir do Decreto Postal. 
No corpus vemos, claramente, a relação de subordinação entre as administrações postais das vilas em relação à Corte e à administração da província. Podemos constatar este procedimento por meio do documento 02 , de 2 de janeiro de 1868, p.101, em que há a autorização exarada pela Directoria Geral dos Correios, acerca da criação de uma agência na Vila de Jaú. Acreditamos que tal notificação deve-se a necessidade de fornecimento de valores, por parte do presidente da província, para que a unidade pudesse realmente existir, após o aceite da administração dos Correios da Corte. Os dizeres do manuscrito remetem a tal procedimento:

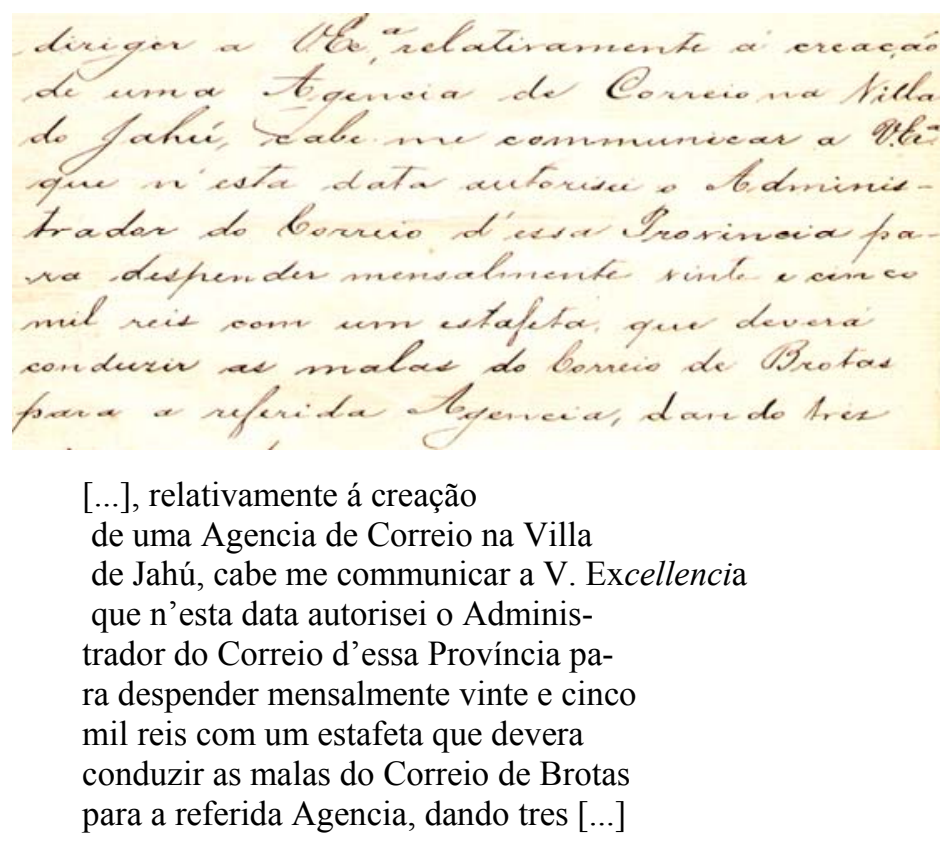

Figura 03 -Trecho do documento 02, das linhas 7 a 15, com transcrição

Nos documentos pesquisados, constatamos a existências desta estrutura. Um dos manuscritos analisados, documento 01, p. 98 , partiu de Lorena, em 28 de novembro de 1833, relatando os motivos de atraso na entrega e foi destinado ao Administrador Geral dos Correios em São Paulo e remetido pelo administrador dos Correios da Vila de Lorena. O documento dá-nos informações que comprovam o Decreto de Março de 1829, pois, demonstra a relação de subordinação dos Correios das vilas à administração geral do Correios, centralizada na capital da província.

O documento 03, p.103, datado de 14 de julho de 1879 e 04, p.107 apontam-nos o uso das linhas férreas no transporte das correspondências. $O$ documento 03 partiu da administração dos Correios de São Paulo e solicitava a intervenção do governante junto a Companhia Inglesa, como trecho abaixo: 


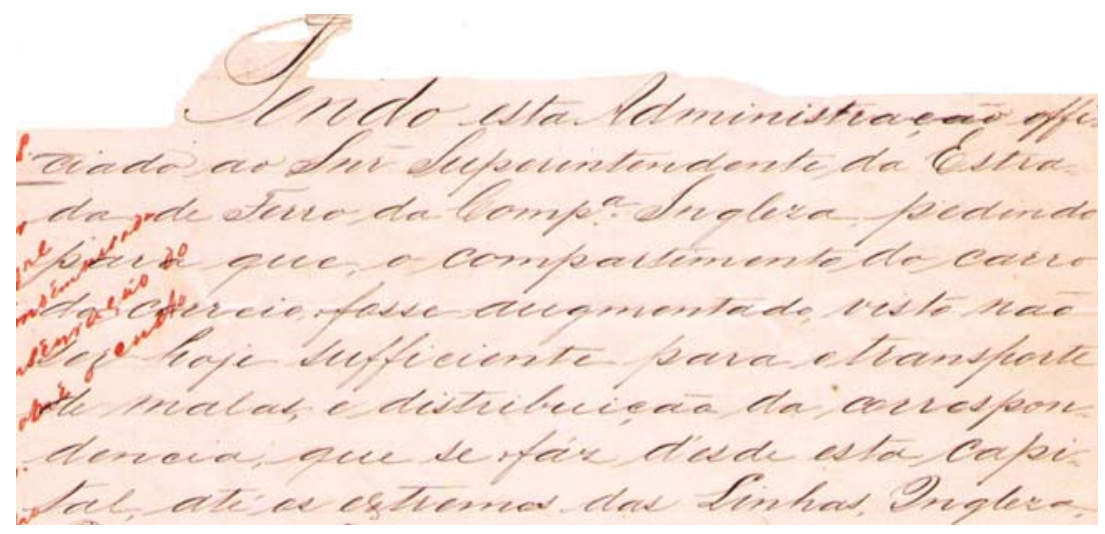

Tendo esta Administração offi ciado ao Senhor Superintendente da Estra da de Ferro da Companhia Ingleza pedindo para que o compartimento do carro do correio, fosse augmentado, visto não ser hoje sufficiente para o transporte de malas, e distribuiçaõ da correspon dencia, que se fáz d'esde esta capi tal, até os extremos das Linhas, Ingleza,

Figura 04 - Trecho do documento 03, das linhas 4 a 12, com transcrição.

No mês seguinte, o presidente da província de São Paulo recebe a resposta à solicitação por meio de documento oficial da Repartição Fiscal da Estrada de Ferro de Santos a Jundiaí, estrada da Companhia São Paulo Railway. O manuscrito 04, sito a p. 107 informava os motivos da não concessão de espaço nos vagões do trem, comprometendo-se a fazê-lo a partir do comunicado, conforme demonstra excerto abaixo:

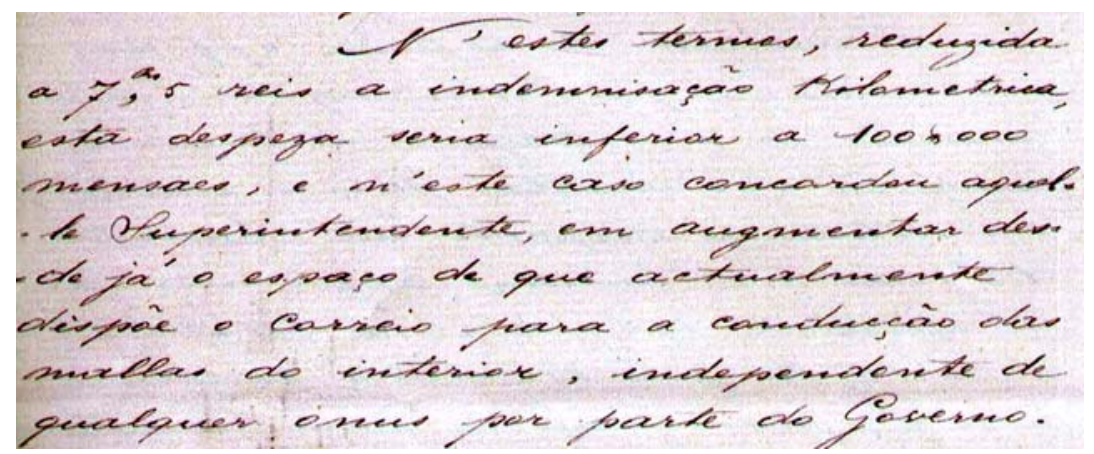

N'estes termos, reduzida a 700,5 reis a indemnisação kilometrica, esta despeza seria inferior a $100 \$ 000$ mensaes, e n'este caso concordou aquel $=$ $=$ le Superintendente, em augmentar des= $=$ de já o espaço de que actualmente dispõe o correio para a conducção das mallas do interior, independente de qualquer onus por parte do Governo.

Figura 05 - Excerto do documento 04, linhas 12 a 20, com transcrição 
O mesmo ocorreu em documento emitido pela Câmara Municipal de S. Manoel. O ofício, documento 07, datado de 24 de abril de 1889, p. 121 manifestava o interesse da população daquela vila na diminuição dos prazos de correios.

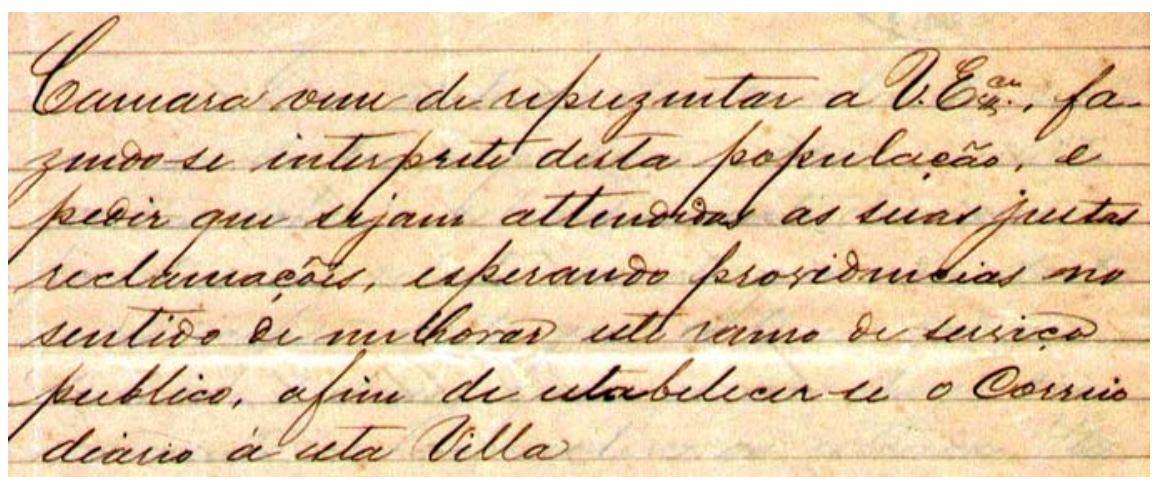

Camara vem de reprezentar a Vossa Excellencia, fazendo-se interprete desta população, e pedir que sejam attendidas as suas justas reclamações, esperando providencias no sentido de melhorar este ramo de serviço publico, afim de estabelecer-se o Correio diario a esta Villa.

Figura 06 - Trecho do documento 07, linhas 48 a 54, com transcrição

Outra característica deste documento é a sua origem. O ofício parte da Camara Municipal de São Manoel do Paraizo, em nome da população da vila. Este procedimento era atribuído à câmara, conforme previa o Decreto de Março de 1829, Capítulo IV - dos agentes dos Correios, art. ${ }^{\circ} 25$, que menciona:

Art. $25^{\circ}$ - Os projectos destes novos estabelecimentos devem calcular-se sobre as mutuas precisões de communicação das povoações em attenção á sua população e relações. Estes projectos principiarão com pequenos ensaios. Os que forem geraes de alguma Provincia, ou de umas para outras serão promovidos pelos Presidentes, ouvido o Conselho de Governo, com approvação de Sua Magestade o Imperador. Os que porém forem particulares de uma ou mais villas ficam encarregafos ás Camaras Municipaes, que darão principio a estas tentativas, estabelecendo três Correios mensaes de umas para outras, cujas despezas fará cada uma dentro dos respectivos districtos, á custa das suas rendas, durante o primeiro anno, dando logo parte do novo estabelecimento aos Administradores das Provincias respectivas, que farão as competentes communicações aos Presidentes, e ao Director Geral [...]. 
Os trechos, em que não havia o transporte férreo, eram realizados por meio de cavalgadura, como o que ocorria entre S. Bento do Sapucaí e Pindamonhangaba, documento que comentaremos a seguir.

O facsímile 05, datado de vinte e seis de março de 1881, p. 111 referencía o roubo de malas transportadas de S. Bento do Sapucaí até a Agência de Correios de Pindamonhangaba. Este fato demonstra que nem todos os trajetos contavam com o transporte via linha férrea e muitos eram realizados por correios pedestres.

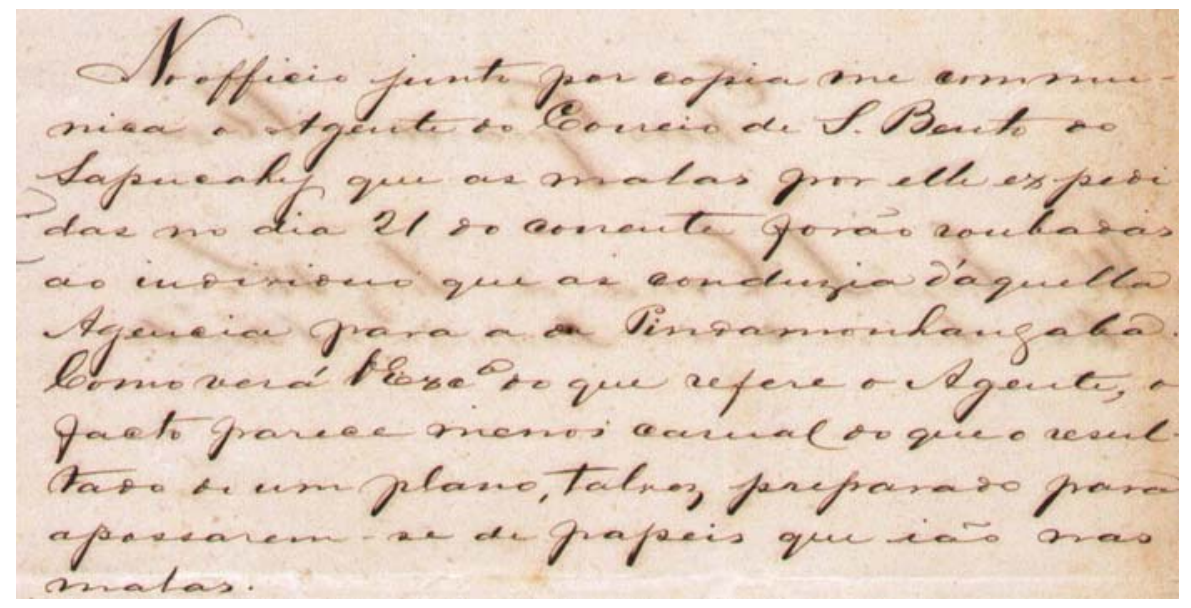

No officio junto copia me communica o Agente do Correio de Saõ Bento do Sapucahy que as malas por elle expedi das no dia 21 do corrente foraõ roubadas do individuo que as conduzia d'aquella Agencia para a de Pindamonhangaba. Como verá Vossa Excellencia do que refere o Agente, o facto parece menos casual do que o resultado de um plano, talvez, preparado para apossarem-se de papeis que iaõ nas malas.

Figura 07 - Trecho do documento 05, linhas 04 a 14, com transcrição.

Este fato demonstra que nem todos os trajetos contavam com o transporte via linha férrea e muitos eram realizados por correios pedestres.

Além dos caminhos abertos pelos bandeirantes, os quais eram utilizados pelos "correios conductores de malas" ou "pedestres" o transporte também era realizado via férrea, principalmente a partir de 1857, quando a S. Paulo Railway passou a funcionar. Os "correios conductores de malas" eram os empregados dos correios que, conforme o Decreto de março de 1829 tinham por atribuição realizar a entrega a particulares. As malas consistiam em sacas com grande quantidade de cartas, que levavam a marca do selo das Armas Imperiais e 
seguiam lacradas até o destino. Pedestres eram os funcionários dos Correios que realizavam a entrega a pé, sem a utilização de outro meio de transporte, como a cavalgadura, por exemplo. Cada pedestre ficava na vila em que as cartas deveriam ser distribuídas, sendo responsáveis por sua distribuição e posterior queima, em caso de não captação das mesmas pelo destinatário.

O corpus mostra-nos os procedimentos do serviço postal e sua influência no âmbito social no estado de São Paulo, no decorrer do século XIX.

\subsubsection{São Paulo no Século XIX e o sistema educacional}

O decreto de março de 1829 menciona a necessidade de conhecimento e especialização dos empregados, conforme cita seu artigo onze:

Art. $11^{\circ}$ - O terceiro Official papelista terá ordenado igual aos dous primeiros; e fica a seu cargo todo o expediente das cartas estrangeiras e dos seguros; e a escripturação dos livros da entrada, e sahida das cartas. Este Official deve saber ao menos a língua ingleza, e a franceza.

Com base no citado em trecho do ofício de 04 de outubro de 1889, documento 08 do corpus, sito à p.127, que menciona:

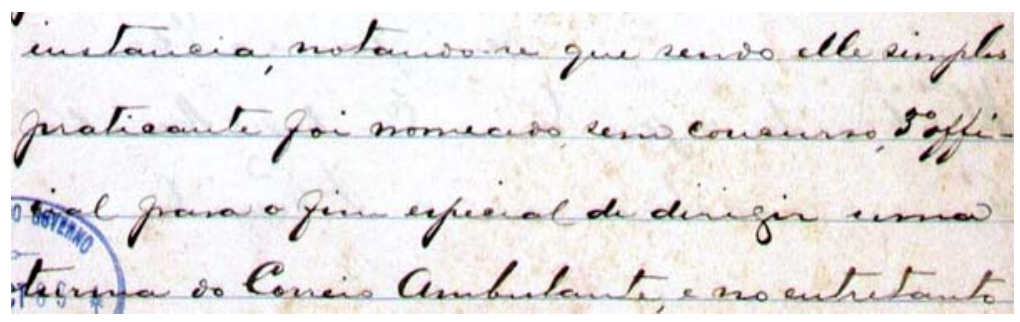

[...] instancia, notando que sendo elle simples praticante foi nomeado sem concurso, terceiro official para o fim especial de dirigir uma turma do Correio Ambulante, e no entretanto [...]

Figura 08 - Parte do documento 08, linhas 20 a 23, com transcrição

Levantamos a hipótese de que os empregados dos Correios eram escolhidos para as diversas funções dentro da instituição e tal escolha possuiria uma exigência mínima. Mas, 
existe um contexto histórico-social que não se pode esquecer: as condições em que a educação era transmitida no Brasil, no século XIX.

Era grande a quantidade de analfabetos na colônia, em meados do século XVIII. Todo o sistema educacional na cidade de S. Paulo era atribuído aos jesuítas e, após sua expulsão, em 1759, houve grande reforma educacional. Foi, ainda, nesse ano, que a educação sofreu grandes transformações, sob a administração de Luiz Antonio Botelho de Souza Mourão, o Morgado de Mateus.

A preocupação principal era a preparação da população, pois a situação era crítica. Gonçalves (1996) em Luzes e Sombras sobre a Colônia afirma que:

(...) o anafalbetismo era generalizado e a falta de pessoas instruídas entravava até mesmo seus projetos na administração da Capitania, posto que defrontava-se com sérias dificuldades em encontrar pessoas aptas a ocupar os cargos públicos. “( $\mathrm{p}$. $57)$.

Na São Paulo do século XIX, como afirma Azevedo Marques (1953):

\begin{abstract}
Escassa era a instrução entre o povo, distribuída por professores régios das primeiras letras, de gramática latina, retórica, filosofia e teologia dogmática, além de um de Moral, pago pela Mitra. Quem quisesse seguir estudos superiores tinha então de transportar-se para Coimbra, a Meca da Ciência entre portugueses e brasileiros.

Conquanto residência do governador, do bispo, do ouvidor da comarca, do juiz de fora e procurador da coroa, do auditor de guerra, do deputado da junta da real fazenda, e do funcionalismo menor, a cidade não exibia um nível intelectual dos mais elevados. (p.75)
\end{abstract}

Como percebemos o sistema educacional não evoluiria muito após um século, e cuida que o Regulamento de Março de 1829 solicitasse o conhecimento da escrita e de outros idiomas.

As escolas eram escassas e funcionavam "em espaços cedidos e organizados pelos pais das crianças e jovens aos quais os professores deveriam ensinar" (Filho e Vidal, 2000, p.21). Foi a partir da segunda década do século XIX que se passou a construir edifícios para abrigar uma quantidade maior de alunos. O objetivo era ensinar a maior quantidade de crianças possível, visando uma 
escola mais rápida, mais barata e com um professor mais bem formado era o que clamavam nossos políticos e intelectuais. O método preconizado, utilizado largamente na Europa, possibilitava, segundo seus defensores que um professor desse aula para até 1000 alunos. (FILHO e VIDAL, 2000, p.21)

As escolas de ensino mútuo foram amplamente difundidas em todas as províncias. Tais escolas tinham como objetivo ensinar as primeiras letras e sua freqüência devia-se ao preparo que a mesmo fornecia, para que o aluno ingressasse no secundário, ou ainda, ocupasse pequenos cargos burocráticos. (RIBEIRO, 1987, p. 41)

Com a independência, criaram-se os cursos jurídicos em Olinda e São Paulo, no ano de 1827. Marcílio (2005) afirma que:

Na cidade de São Paulo imperial houve quatro tipos de ensino secundário público. O primeiro resumia-se em aulas públicas avulsas de latim e francês e em aulas em escolas particulares, de disciplinas que constavam das exigências dos exames de habilitação para o acesso às faculdades. $\mathrm{O}$ segundo, o mais procurado, eram os chamados cursos preparatórios de ingresso às academias de ensino superior do império, ministrados "oficialmente" na própria Faculdade de Direito sob a responsabilidade do governo central. O terceiro era o da Escola Normal preparatória do mestre-escola de primeiras letras, a primeira criada em 1846, com existência intermitente e extremamente precária. Finalmente, havia o Seminário Episcopal criado em 1851 na cidade, que não só preparava moços para a carreira sacerdotal como também aqueles que, sem pretenderem se tornar padres, almejavam o ensino superior. (p. 74)

Complementa, ainda, afirmando que:

O ensino secundário público da cidade de São Paulo, em 1835, contava com as aulas de latim, com 14 alunos, de filosofia racional e moral, com 19 alunos; de retórica com 30 alunos; de francês e inglês, com 41; de história e geografia, com 36 frequentes. (p.77)

No Rio de Janeiro, tem-se como exemplo o Colégio Dom Pedro II. No ano de 1854, a instrução pública, que abrangia somente este colégio, tinha a

[...] A duração dos cursos era de sete anos. Ensina-se grego, latim, inglês, francês, alemão, italiano, filosofia racional e moral, retórica e poética, incluindo nesta a língua e literatura portuguesa, história, geografia, matemáticas elementares, isto é, aritmética, álgebra até equações de segundo grau, geometria e trigonometria retilínea, as ciências naturais, a física, a química, o desenho, a música, a dança e a ginástica. (ALMEIDA, 2000, p. 92) 
Os escribas, responsáveis pela elaboração dos documentos, possivelmente, nasceram no início e meados do século XIX e apoiamo-nos neste período para avaliar o nível de escolaridade dos paulistas.

Diante disso, compreendemos que a aprendizagem de outros idiomas era possível, embora, não fosse facilmente conquistado, devido às condições educacionais da época. Concluímos, então, que o aprendizado de línguas estrangeiras era possível no século XIX, o que reforça a formação dos escribas e o conhecimento da escrita. 


\section{O corpus}

\subsection{Descrição dos manuscritos analisados}

Classificamos os facsímiles analisados de acordo com as relações burocráticas que estabeleciam como ascendentes, descendentes ou horizontais. Conforme Belloto (2002, p. 37) compreende-se como descendentes os documentos que partem do rei e tem como destino os súditos ou autoridades inferiores. Como ascendentes os que sobem dos súditos às instâncias superiores e como horizontais os que são trocados entre autoridades ou setores do mesmo nível.

No presente corpus a autoridade máxima não é o rei, mas sim o presidente da província ou o administrador geral dos correios da província. Os autores dos documentos são funcionários da Administração dos Correios na província de São Paulo e do Rio de Janeiro, e em dois casos específicos, escribas da Companhia Inglesa de Estrada de Ferro e representante da Câmara de São Manuel.

Para esclarecermos a classificação documental, explicaremos a organização hierárquica dentro da administração dos Correios, no século XIX. Como citado no primeiro capítulo, a centralização da administração postal na capital do império, a partir da independência, proporcionou uma autonomia à instituição. Com isso, criou-se uma estrutura de dependência entre os estados e a sede dos Correios, denominada, Diretoria Geral. Cada província possuía uma administração e as rotas de correios, assim como, as agências (pontos de centralização das cartas criados em vilas e cidades) eram subordinadas a tal gerenciamento, com autonomia do estado ao qual a administração estava localizada.

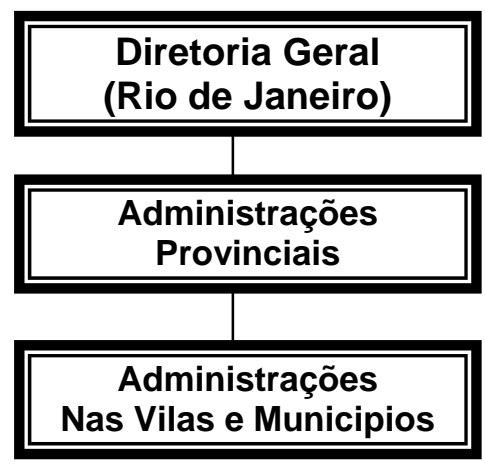

Figura 09 - Organograma da Administração dos Correios a partir do Decreto de 1829.

(Fonte: Adaptado de Barros Neto, João Pinheiro. Administração pública no Brasil: uma breve história dos Correios. São Paulo: Anablume, 2002) 
Mas, além da subordinação à Diretoria Geral, havia também a necessidade de informação à presidência da província local para quaisquer atos que envolvessem mudança na estrutura dentro da província. É por tal motivo, que grande parte do corpus é encaminhado ao presidente da província de São Paulo, que dava o aval às solicitações referenciadas aos trâmites dos serviços de Correios. Embora, o administrador geral de Correios local fosse a autoridade máxima para os assuntos postais, todas as questões que envolvessem os serviços postais deveriam ser transmitidas ao presidente da província. Essa relação de dependência está prevista no Decreto de Março de 1829, já citado no capítulo anterior.

Confirmamos tal evidência no manuscrito 03, p. 103 que relata a reclamação sobre a falta de espaço para o transporte de cartas nos vagões nos trens da Companhia de Estradas de Ferro.

Tendo em vista essa relação de dependência, entendemos que as administrações provinciais eram subordinadas ao governo da província de São Paulo. O mesmo ocorre com a câmara dos deputados de São Manoel e com a Companhia de Estradas de Ferro. A primeira obedece a uma subordinação natural prevista na Constituição de 1823 e reiterada pelo Decreto de Março de 1829. A Constituição Imperial afirma:

\author{
TITULO $7^{\circ}$ \\ CAPITULO II. \\ Das Camaras. \\ Art. 167. Em todas as Cidades, e Villas ora existentes, e nas mais, que para o \\ municipal das mesmas Cidades, e Villas. \\ Art. 168. As Camaras serão electivas, e compostas do numero de Vereadores, que a \\ Lei designar, e o que obtiver maior numero de votos, será Presidente. \\ Art. 169. O exercicio de suas funcções municipaes, formação das suas Posturas \\ policiaes, applicação das suas rendas, e todas as suas particulares, e uteis attribuições, \\ serão decretadas por uma Lei regulamentar.
}

Já, a Companhia de Estrada de Ferro tratava-se de uma empresa do ramo privado, mas a licença para a construção e exploração das linhas férreas era dada pelo governo provincial, que as mantinha sob seu controle. O Decreto 1930 de 26 de abril de 1857 confirma estas prerrogativas em seu Artigo $6^{\circ}$, que menciona “Do juizo da Administração, quando offender a propriedade de alguem, haverá recurso para o juizo arbitral, e da decisão deste para o Governo na Côrte e para os Presidentes nas Provincias".

Também pertencia ao governo o direito de examinar as locomotivas. $\mathrm{O}$ referido decreto também ajuda a explicar o contexto de um dos documentos do corpus, que menciona a supervisão dos engenheiros fiscais a serviço do governo. 
A relação de hierarquização também se explica com a análise do conteudo dos documentos, que será realizada e explanada na tabela 01, p. 31.

Os documentos eram ofícios, pois se tratavam de comunicações trocadas entre órgãos do governo. Todos possuem a mesma forma de apresentação, assim definida por Belloto (2002, p. 77)

O título abreviado - of., seguido da sigla do órgão expedidor e do número do ofício. Depois vêm as datas tópica e cronológica. Em seguida, a direção e o vocativo Senhor. Por último o texto propriamente dito, antecedendo o fecho de cortesia e a assinatura do emitente.

O corpus possui tais características e os mesmos tratamentos no vocativo e no fecho de cortesia. A evocação é "Ilustríssimo, Excelentíssimo Senhor" e o fecho a menção "Deus Guarde a Vossa Excelência, Ilustrissimo e Excelentíssimo Senhor”. Essas características estão presentes nos documentos do início do século XIX até o ano de 1889. Embora o tratamento Excelência estivesse previsto na Lei 40 de três de outubro de 1834, os tratamentos dispensados nos ofícios são mais formais, demonstrando maior distanciamento e cortesia.

Tais tratamentos presentes em todos os ofícios são parte do modelo de boa escrita da época. Podemos identificá-los no Novo Secretário Portugues de José Ignacio Roquete (1860).

Acreditamos que tal manual tenha sido utilizado, não somente pelos Correios, mas pelos demais órgãos do governo, pois os ofícios que partiram da Câmara Municipal de São Manoel e da Companhia de Estrada de Ferros Santos-Jundiai possuíam as mesmas características e não foram elaborados pela administração dos Correios. Podemos verificar a diversidade da origem analisando os timbres de cada ofício, presentes na parte superior de cada documento. Essas informações serão detalhadas no terceiro capítulo.

O Novo Secretário Português (1860) trazia longa lista de evocações e despedidas a serem utilizadas nos diversos tipos de comunicação escrita. Em seu prólogo cita o "Código de bom tom" e as "varias outras particularidades que não são para desprezar se quizermos passar por gente bem criada, e que conhece as regras de bem viver". Complementa fornecendo-nos as fórmulas que devem ser utilizadas em tratativas oficiais afirmando que:

\footnotetext{
Como nas correspondências das confrarias e associações se costuma usar das mesmas fórmulas, que nas públicas ou officiaes; diremos qual é a praxe seguida nestas, afim de se poder empregar quando for necessário,. No alto do officio põe-se o tratamento devido á pessoa; por exemplo: $\mathrm{Ill}^{\mathrm{mo}} \mathrm{Ex}^{\mathrm{mo}} \mathrm{Sn}^{\mathrm{r}}$, e no fim escreve-se em regra separada: Deus Guarde a V. ( 1860, p. 11)
}

A partir de novembro de 1889 os tratamentos mudam e identificamos o vocativo Ilustre Cidadão e o fecho Saúde e Fraternidade. Essa mudança reflete o fim do império e as 
influências positivistas da época. Todos os documentos foram escritos no decorrer do século XIX e o critério para a escolha desses textos foi o seu conteúdo e as possibilidades de resgate histórico, como já mencionado na introdução. Para análise descritiva e compreensão de posterior análise paleográfica os facsímiles foram organizados cronologicamente, conforme tabela a seguir:

Tabela 01 - Relação dos documentos analisados

\begin{tabular}{|c|c|c|c|c|c|c|}
\hline $\begin{array}{l}\text { Doc./ } \\
\text { P. }\end{array}$ & Fólios & $\begin{array}{c}\text { Remetente e órgão } \\
\text { de Origem }\end{array}$ & $\begin{array}{c}\text { Destinatário e órgão } \\
\text { de destino }\end{array}$ & Autoria & $\begin{array}{c}\text { Aspecto } \\
\text { burocrático e } \\
\text { conteúdo }\end{array}$ & Data \\
\hline $01 / 97$ & 01 & $\begin{array}{l}\text { José Alves da Fonçeca, } \\
\text { adm. dos Correios da } \\
\text { Vila de Lorena }\end{array}$ & 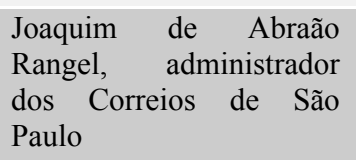 & Apógrafo & $\begin{array}{l}\text { Ascendente./ } \\
\text { Ofício relata os } \\
\text { motivos do atraso. }\end{array}$ & $27 / 03 / 1833$ \\
\hline $02 / 101$ & 01 & $\begin{array}{l}\text { Luis B. Lima d'a Silva, } \\
\text { diretor geral dos } \\
\text { Correios do Rio de } \\
\text { Janeiro }\end{array}$ & $\begin{array}{l}\text { Presidente da Província } \\
\text { de São Paulo }\end{array}$ & Apógrafo & $\begin{array}{l}\text { Ascendente./ } \\
\text { Solicitação de } \\
\text { criação de agência }\end{array}$ & $02 / 01 / 1868$ \\
\hline $03 / 103$ & 01 & $\begin{array}{l}\text { Jose Luis Nery da } \\
\text { Silva, adm. dos } \\
\text { Correios de S. Paulo }\end{array}$ & $\begin{array}{ll}\text { Laurindo Abelardo de } \\
\text { Brito, presidente } \\
\text { província de S. Paulo }\end{array}$ & Apógrafo & $\begin{array}{l}\text { Ascendente./ } \\
\text { Solicitação de } \\
\text { aumento do espaço } \\
\text { nos vagões }\end{array}$ & $14 / 07 / 1879$ \\
\hline $04 / 107$ & 01 & $\begin{array}{l}\text { Eduardo Jose de } \\
\text { Moraes, } \\
\text { Superintendente Fiscal } \\
\text { da Estrada de Ferro de } \\
\text { Santos }\end{array}$ & $\begin{array}{ll}\text { Laurindo Abelardo de } \\
\text { Brito, presidente } \\
\text { província de S. Paulo }\end{array}$ & Apógrafo & $\begin{array}{l}\text { Ascendente./ } \\
\text { Resposta } \\
\text { solicitação } \\
\text { realizada } \\
\text { documento } 03\end{array}$ & 08/08/1879 \\
\hline $05 / 111$ & 01 & $\begin{array}{l}\text { José Francisco Soares, } \\
\text { adm. dos Correios de } \\
\text { S. Paulo }\end{array}$ & $\begin{array}{l}\text { Conde de Três Rios, } \\
\text { presidente da província } \\
\text { de S. Paulo }\end{array}$ & Apógrafo & $\begin{array}{l}\text { Ascendente./ } \\
\text { Relato de assalto } \\
\text { no trajeto postal }\end{array}$ & $26 / 03 / 1881$ \\
\hline $06 / 115$ & 02 & $\begin{array}{l}\text { José Francisco Soares, } \\
\text { adm. dos Correios de } \\
\text { S. Paulo }\end{array}$ & $\begin{array}{l}\text { Visconde de Itú, vice- } \\
\text { presidente da província } \\
\text { de S. Paulo }\end{array}$ & Apógrafo & $\begin{array}{l}\text { Ascendente./ } \\
\text { Denúncia de } \\
\text { violação de cartas }\end{array}$ & $11 / 05 / 1883$ \\
\hline $07 / 121$ & 02 & $\begin{array}{l}\text { Câmara Municipal de } \\
\text { São Manoel do Paraíso }\end{array}$ & $\begin{array}{l}\text { Barão de Jaguara, } \\
\text { presidente da província } \\
\text { de S. Paulo }\end{array}$ & Apógrafo & $\begin{array}{ll}\text { Ascendente./ } & \\
\text { Solicitação } & \text { de } \\
\text { diminuição } & \text { do } \\
\text { prazo postal. } & \end{array}$ & $24 / 04 / 1889$ \\
\hline $08 / 127$ & 01 & $\begin{array}{l}\text { Manoel Marquez de } \\
\text { Sá, adm. dos Correios } \\
\text { de S. Paulo }\end{array}$ & $\begin{array}{l}\text { José Vieira Couto de } \\
\text { Magalhães, presidente da } \\
\text { província de S. Paulo }\end{array}$ & Apógrafo & $\begin{array}{ll}\text { Ascendente./ } & \\
\text { Reclassificação de } & \text { de } \\
\text { agência } & \text { de } \\
\text { Correios } & \end{array}$ & $04 / 10 / 1889$ \\
\hline 09/131 & 02 & $\begin{array}{l}\text { Manoel Marquez de } \\
\text { Sá, adm. dos Correios } \\
\text { de S. Paulo }\end{array}$ & $\begin{array}{l}\text { Barão de Jaguara, } \\
\text { presidente da província } \\
\text { de São Paulo }\end{array}$ & Apógrafo & $\begin{array}{lr}\text { Ascendente./ } \\
\text { Parecer } & \text { sobre } \\
\text { solicitação } & \text { de } \\
\text { funcionário. } & \end{array}$ & $15 / 05 / 1889$ \\
\hline $10 / 137$ & 01 & $\begin{array}{l}\text { Manoel Marquez de } \\
\text { Sá, adm. dos Correios } \\
\text { de S. Paulo }\end{array}$ & $\begin{array}{l}\text { Prudente José de Moraes } \\
\text { Barros, presidente da } \\
\text { província de São Paulo }\end{array}$ & Apógrafo & $\begin{array}{ll}\text { Ascendente./ } & \\
\text { Parecer acerca da } & \text { da } \\
\text { solicitação } & \text { do } \\
\text { documento } 08 . & \end{array}$ & $14 / 01 / 90$ \\
\hline
\end{tabular}


Iniciaremos com a descrição do documento 01, de 1833, que partiu da Vila de Lorena. Este documento é ascendente, ou seja, destinado a alguém, cuja hierarquia é superior a do emissor. É o único documento que possui marcas de dobraduras e do sinete que o fechou. A diferença deste documento para os demais é, justamente, as marcas de dobraduras que demonstram ser o ofício e o envelope o mesmo objeto. Pelas marcas, supomos que passou pelos trâmites normais de envio: transporte terrestre, ou fluvial e finalmente a entrega realizada por um praticante, que era "empregado no serviço de entregar cartas ao povo dentro do correio; pesar, e marcar as que o precisarem". (Decreto de 05 de março de 1829). Seu remetente é o Administrador do Correio de Vila de Lorena e o manuscrito foi encaminhado ao Administrador Geral dos Correios de São Paulo, em 19 de novembro de 1833. Seu teor relata os motivos dos atrasos ocorridos na entrega das correspondências.

O manuscrito datado de 02 de janeiro de 1868, denominado documento 02, partiu da Diretoria Geral no Rio de Janeiro e foi enviado para a presidência da província de São Paulo. Solicita a criação de uma Agência de Correios na Vila de Jaú. O documento demonstra a estrutura de Correios da época: a centralização na capital do império que autoriza a criação ou fechamento de linhas de correios e agências.

Para o ano de 1879, há dois documentos. Respeitando ordem cronológica, o primeiro data de 14 de julho, e o segundo de 08 de agosto, respectivamente numerados como 03 e 04 . O primeiro trata de uma solicitação de espaço nos vagões de carga da linha férrea, para transporte das malas de correios. O segundo manuscrito não parte de uma Administração dos Correios, mas sim do Ministério das Estradas, Repartição 1, Estrada de Ferro de Santo Jundiaí, em resposta a solicitação do documento de 14 de julho. Informa a concessão de vagão para o transporte das malas do Correio. Ambos foram destinados ao presidente da província de S. Paulo e seus emissores foram representantes de órgãos subordinados ao governo da província, por isso, os documentos são ascendentes.

No ano de 1881, abordaremos o manuscrito originário da Administração Central dos Correios em São Paulo. O documento 05 é datado de 26 de março de 1881 e assinado pelo Administrador José Francisco Soares e destinado ao Conde de Três Rios, então presidente da província de São Paulo. É um documento ascendente, que relata um roubo ocorrido entre o trajeto de São Bento do Sapucaí para Pindamonhangaba, mencionando ainda a suspeita de envolvimento de um ambulante (funcionário do Correios, responsável por curtos roteiros). $\mathrm{O}$ ofício também solicitava providências ao governo.

Datado de 11 de maio de 1883, o ofício trata sobre a possibilidade de violação de carta transportada pelo Correio. O documento parte da Administração do Correio de São Paulo e 
destina-se ao presidente da província, Visconde de Itu. O manuscrito, número 06 , solicita a abertura de sindicância para apurar o ocorrido.

Do ano de 1889, há três facsímiles, dos quais dois partem da Administração Geral dos Correios e um parte da Câmara Municipal de São Manoel do Paraíso. O manuscrito que partiu da vila de São Manoel, identificado com o número 07, foi elaborado em 24 de abril de 1889, por moradores da vila, representados pela Câmara. Direcionado ao presidente da província de S. Paulo, Barão de Jaguara, trata-se de um documento ascendente, que solicita a criação de entrega diária de cartas na vila.

O manuscrito de 15 de maio de 1889 é a resposta, dada pela Administração Geral dos Correios de São Paulo, ao presidente da província paulista acerca da solicitação de reclassificação do porte da agência de Correios situada na vila de São Manoel do Paraíso. Este documento, número 09, é ascendente, pois seu emissor é a Administração dos Correios de S. Paulo e o destinatário a presidência da província de São Paulo.

O documento datado de 04 de outubro de 1889, número 08 , foi enviado ao presidente da província José Vieira Couto de Magalhães. Esse documento é ascendente e foi remetido pelo Administrador Geral dos Correios de São Paulo. Trata-se de uma parecer desfavorável à solicitação de licença de um funcionário, que não tem realizado corretamente seu trabalho de correio ambulante, alegando problemas de saúde.

O documento 10, de 14 de janeiro de 1890, é a resposta à solicitação dos moradores da Vila de S. Manoel de elevação de categoria de agência de correios em S. Manoel. O documento é ascendente, pois foi destinado ao presidente da província de São Paulo, José de Moraes Barros Neto. 


\section{Aspectos Codicológicos}

\subsection{A superfície}

Todos os ofícios foram manuscritos em papel, com logotipo da instituição da qual se originaram, com exceção do documento um, que não possui marca dos Correios, no entanto, traz marcas de selagem e dobraduras, que aparecem em todo o manuscrito. No verso do texto há informações de remetente e destinatário. Foi utilizado um material como lacre, cujos resquícios apresentam a cor verde. Ao abrirmos a carta, verificamos que parte do documento ficou colada no material, o que acreditamos ser uma espécie de cera, ou material semelhante.

Não há marcas de sinete, mas o formato retangular permaneceu no papel. Àquela época ainda não existia o selo $^{3}$ que conhecemos hoje, em papel e estampilhas, e sim selos moldados sobre cera. Sua cor era verde e permaneceu no documento em relevo, mas sem marcas de números ou resquícios da imagem.

Ao redor do selo constam marcações numéricas, que se referem à tarifa de transporte do documento, pois "estas taxas manuscritas eram lançadas sobrecarta pelos administradores, que eram nomeados pelas respectivas Câmaras Municipais e provados pelos Governos Provinciais" (ROSARIO, 1993, p. 66)

Como o envelope e a carta são o mesmo documento, as marcas de dobragem mantiveram-se também sobre o texto manuscrito, mas sem prejudicar a leitura. É o único documento com marcas de dobras e desgaste físico, dentre elas a corrosão por traças.

O tom da maioria dos documentos é semelhante, pois foram elaborados sobre o mesmo tipo de papel, no formato in fólio, em sua maioria com pauta e sem filigranas. Observamos, porém, que as cores das pautas encontradas não coincidem com as cores da tinta empregadas na escrita do documento.

\footnotetext{
O primeiro selo foi criado na Inglaterra em 3 de dezembro de 1839. O Brasil foi o segundo país no mundo a criar um selo e isso ocorreu em 1 de agosto de 1843. As estreitas relações comercias existentes entre Brasil e Inglaterra foram fatores impulsionadores da criação do selo, além, das questões mercantis que envolviam a cobrança dos serviços postais. Até a criação do selo o pagamento pelo trajeto das correspondências era pago ao retirarem-se as cartas nas agências de Correios, o que muitas vezes não ocorria. O olho de boi foi o primeiro selo brasileiro e todo cidadão que enviasse uma carta deveria pagá-la no ato da postagem. O comprovante do pagamento era o selo que possuía um valor facial. Os selos Olho de Boi possuíam valor facial de 0,30; 0,60 e 0,90 centavos. Desde o século XIX a elaboração dos selos tem se aprimorado e uma grande variedade de materiais, cores e motivos são alvos dos selos, que contam a história de instituições, nações, abordando também assuntos da atualidade.
} 
Os documentos são acondicionados na posição vertical dentro de latas de alumínio. Como todos os manuscritos são documentos avulsos, ou seja, não estão encadernados em formato de livro, são acondicionados conjuntamente, mas separados por ordem cronológica.
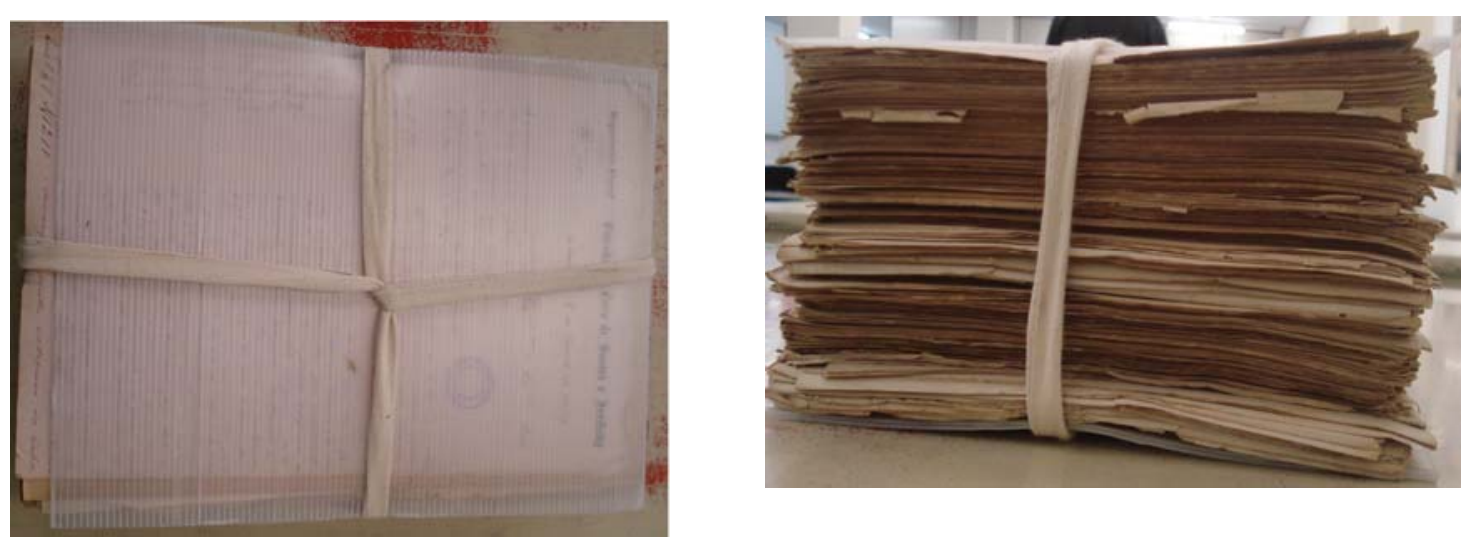

Figura 10 - Acondicionamento documental

Há duas capas plásticas que impedem o contato direto da fita com o documento na maior extensão do documento, embora tal estratégia não impeça seu desgaste. A fita toca as bordas dos fólios, desgastando-os. A fita que envolve os documentos possui 2,5 cm de largura é $1,5 \mathrm{~cm}$ de comprimento. Percebemos isso ao verificar as laterais, que já apresentam marcas de desgaste e fissuras, no entanto, grande parte do documento está em perfeitas condições.

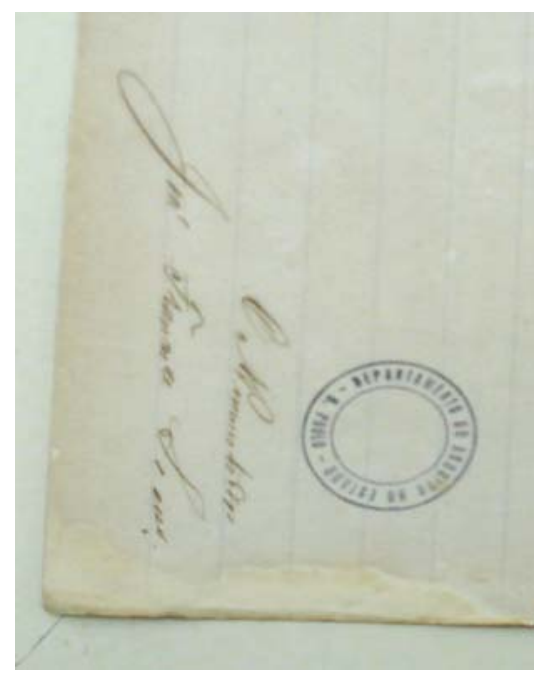

Figura 11- Bordas das folhas 
Não há marcas de brocas ou de ataque de qualquer outro tipo de inseto. Seu formato é o in-fólio, caracterizada como uma grande folha dobrada em dois com quatro páginas. Os documentos medem $30 \mathrm{~cm}$ de comprimento x $22 \mathrm{~cm}$ de largura. Trata-se de uma apel grosso e resistente. Sua cor varia entre o bege e o rosa, não havendo um padrão, pois os documentos foram elaborados independentemente, o que pressupõe origens diferentes dos papéis.

Grande parte do papel consumido na colônia era produzida na Europa, pois não possuíamos fábricas para sua elaboração. Após a chegada da família real portuguesa foi fundada primeira fábrica de papel em 1808-1810 por Henrique Nunes Cardoso e Joaquim José da Silva (Martins, 1996, p. 124).

\subsection{Marcas Oficiais}

Os manuscritos apresentam marcas oficias. São elas: "Directoria Geral dos Correios", "Administração do Correio" ou "Administração do Correio de São Paulo" no canto superior esquerdo, da primeira folha de cada fólio. Estas marcas denotam a oficialidade dos documentos dentro e fora da instituição.

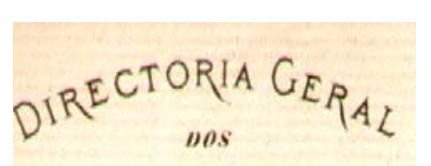

\section{CORREIOS}

Figura 12 - Logotipo da Directoria Geral dos Correios

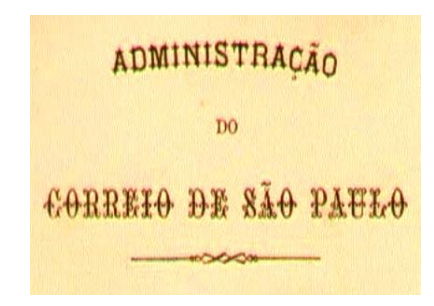

Figura 13 - Logotipo da Administração do Correio de São Paulo

A marca com identificação do Correio de São Paulo foi encontrada somente no documento três. Nos demais foram encontradas variantes do logotipo como as mencionadas na figura 13 . 

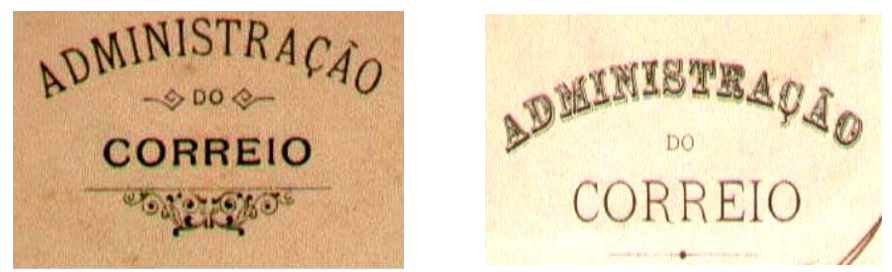

Figura 14 - Logotipos da Administração dos Correios. À esquerda presente em documento de 1889 e à direita logo presente em documento de 1883

Todas possuem 2,5 cm de largura por $2 \mathrm{~cm}$ de altura apresentam-se, sempre, na cor castanha. Abaixo da marca há indicação para numeração do ofício. A numeração constituía-se em controle de circulação da documentação interna e externamente e era individual.

Nos documentos quatro e sete, que não partiram da Administração dos Correios, consta no início do título do documento a organização de origem dos mesmos, que em ambos os casos foram respectivamente a "Estrada de Ferro de Santos a Jundiahy" e a "Camara Municipal de S.Manoel do Paraizo”.

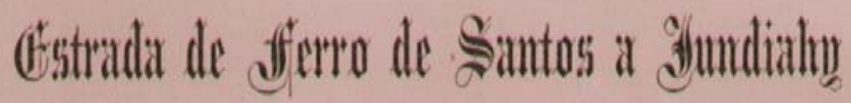

Figura 15- Timbre da Estrada de Ferro de Santos a Jundiahy

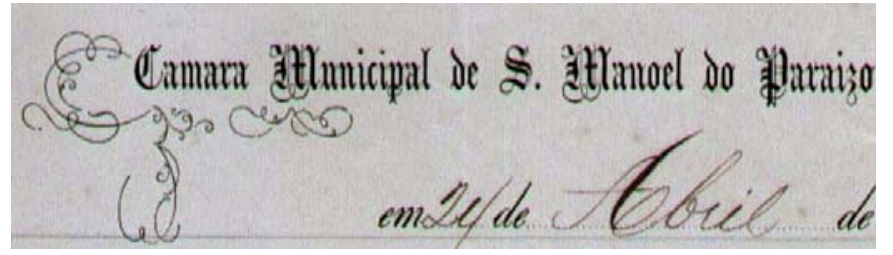

Figura 16- Timbre da Camara Municipal de São Manoel do Paraiso

Abaixo desta informação há a indicação do $\left\langle\mathrm{N}^{\circ}>\right.$ em que deveria constar o número de controle interno.

O carimbo do Arquivo do Estado de S. Paulo consta em todos os documentos, impresso na cor azul ou preto. Conforme informações da instituição tais marcações passaram a ser apostas em todos os documentos do arquivo a partir de catalogação a partir da década de 1950. O carimbo não foi aposto sobre a parte escrita do texto em nenhum dos manuscritos. 


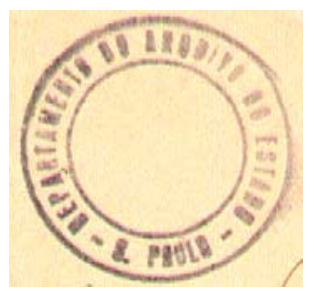

Figura 17- Carimbo circular do Arquivo do Estado de São Paulo

O carimbo acima não sobrepôs à parte escrita. Sempre, em formato circular, com diâmetro de $2.0 \mathrm{~cm}$, o carimbo da instituição traz em seu interior a menção "Departamento de Arquivo do Estado - S. Paulo".

Já o carimbo da Secretaria do Governo possui formato oval, como apontado abaixo:

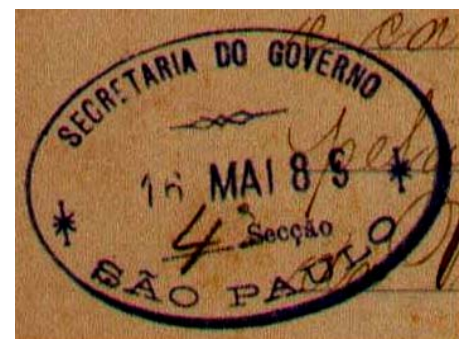

Figura 18 - Carimbo de Controle Interno

O carimbo da figura 16 tem em seu interior a informação do órgão ao qual pertencia, além da data. Compreendemos que se trata de um carimbo datador, pois, ao cruzarmos as informações da data presente no interior do carimbo com a datação do ofício constata-se a aproximação das datas.

Verifica-se, ainda, a menção de seção, marca a lápis, logo abaixo da data. Dentro do carimbo consta a menção "Secretaria do Governo - São Paulo". Aposto no rodapé ou na parte superior do manuscrito, o carimbo datador possuía $3 \mathrm{~cm}$ de largura por $2 \mathrm{~cm}$ de altura com tinta na cor azul. Ao contrário do carimbo do Arquivo do Estado, esse carimbo sempre é aposto no canto inferior esquerdo.

Os documentos são acondicionados na posição vertical dentro de latas de alumínio. Como todos os manuscritos são fólios avulsos são acondicionados juntamente. 


\subsection{Tinta e Instrumento}

Todos os documentos foram manuscritos com tinta na cor castanha escura. Percebemos, nos documentos cinco, seis e oito, que as hastes e caudas dos grafemas apresentam uma textura mais grossa, possivelmente proveniente do instrumento de escrita.

Tendo em vista o período em que foram elaborados, supomos que o material utilizado na escrita foi a pena metálica, o que confere à escrita traçado firme e regular. Esta diferença de traçado foi encontrada em todos os documentos analisados, com variações devido ao aspecto caligráfico de cada escriba.

A tinta empregada provavelmente era a "tinta negra, a base de sulfato de ferro adicionada à gordura dissolvida; com o tempo tornava-se de tonalidade castanha" (ACIOLI, 1994, p.10). Era adicionada a tinta também pequena porção de vinagre para que os insetos não corroessem o papel, devido à presença de gordura. 


\section{Segunda Parte}

\section{Aspectos paleográficos}

\subsection{Aplicação da paleográfica nos documentos analisados}

A paleografia é a ciência que estuda a grafia de documentos antigos, trazendo à luz da escrita moderna, as características particulares dos traçados e particularidades deste tipo de instrumento. Para Mendes (2008, p. 17) a paleografia é a "capacidade de superar as vicissitudes sofridas pela escrita. O conhecimento de sua origem, evolução e época”. Já Acioli (1993, p. 05) afirma que sua função é "ler e interpretar as formas gráficas antigas, determinar o tempo e lugar em que foi escrito o manuscrito, (...) com o fim de fornecer subsídios à História, à Filologia e a outras ciências que tenha a escrita como fonte de conhecimento". Etimologicamente, a palavra paleografia origina-se da aglutinação de duas palavras do grego: $\pi \alpha \lambda \alpha$ ı́́ (antiga) e $\gamma \rho \alpha \varphi \eta ́$ (escrita).

Se analisarmos a etimologia da palavra percebe-se que sua função, nos dias atuais, é bem mais abrangente, o que é natural. Dentro de um contexto linguístico histórico, documentos do século XIX são representantes do período moderno da língua portuguesa. Tal periodização da língua portuguesa é defendida por Cardera (2006, p. 96) em O essencial para a história do português. Mattos e Silva (2006, p. 25) aborda diversas proposta para a periodização da língua portuguesa e todas apontam para a denominação português moderno a língua do século XIX. Logo, a escrita antiga não é mais o único fim da paleografia.

Além disso, a escrita cursiva humanística, característica do século XIX, não impõe tantas dificuldades à leitura, como apresentam documentos setecentistas e principalmente os seiscentistas.

Diante disso, nossa análise paleográfica terá como foco central traçar a semelhança de traçado dos punhos, a fim de estabelecer a quantidade de escribas responsáveis pela escrituração dos ofícios. Esse procedimento faz-se necessário para verificar a quantidade de oficiais responsáveis pela elaboração dos documentos, confirmando a habilidade dos punhos.

A escrita dos facsímiles é caracterizada por uma escrita cursiva, que surgiu com a necessidade de substituição do material rústico por materiais mais finos e, neste caso, citamos o papiro, em substituição às tabuinhas de cera ou de madeira.

É a partir da escrita humanística e com o uso do pergaminho e do papel, materiais moles, que a escrita cursiva surgiu, promovendo uma intensa modificação nos formatos e 
desenvolvimento das letras, pois os instrumentos utilizados, pena de ave e metálica, exigiam menos elaboração e força.

Sabe-se que com a necessidade de transmitir sua interpretação de mundo e seus pensamentos, o homem passou a perpetuar suas marcas deixando-as em materiais diversos. Da argila, em que "o homem iniciou a descoberta da possibilidade de transmissão da sua idéia” (MENDES, 2008, p.41) até o papel, material, que “(...) segundo se diz, descoberto na China e de lá trazido por viajantes para o mundo ocidental” (MARTINS, 1996, p. 111), ocorrendo a partir de então, a gradativa substituição do pergaminho. O papel possuía características que possibilitavam sua utilização em ampla escala, unindo a isto a facilidade de obtenção de matéria prima e fabricação do material.

Dos materiais necessários para marcar, o homem utilizou do machado de sílex à pena de ave, posteriormente substituída pela pena metálica, em fins do século XIX. As tintas utilizadas possuíam diversas cores, relacionando-se "as tintas vegetais à base de tanino e corantes vegetais, as tintas animais (ciba, negro de fumo) e as tintas minerais (ouro, prata (...))”. (MENDES, 2008, p. 52), materiais estes que imprimiam nas folhas as mais variadas cores. Com a evolução dos instrumentos utilizados na escrita, novas características foram empregadas nos documentos, no decorrer dos séculos.

Quanto à escrita, Berwanger \& Leal (2008, p. 68) afirmam que a "maioria da documentação brasileira está registrada em letra humanística, aliás, a escrita humanística é a corrente usual até hoje, desde o séc. XVI".

As letras maiúsculas caem em quase desuso "persistindo, contudo, o uso de maiúsculas capitais nos inícios dos textos ou de parágrafos" (ACIOLI, 1993, p. 40) e as minúsculas farão parte deste tipo de escrita em quase totalidade. Excetuam-se os inícios de frases, substantivos próprios e tratamentos formais, reservados às evocações e saudações.

A origem dos grandes traçados em letras iniciais é caracterizada pela utilização da letra uncial, cuja inserção de prolongamentos, passa a fazer parte dos manuscritos, a partir do século IV d.C. Este tipo de letra produzia um efeito ornamental à escrita. Podermos verificar essas características na evocação dos documentos 09, p. 131 e 07. p.121.

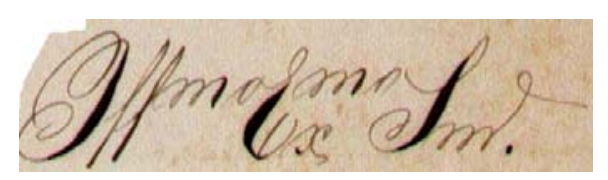

Figura 19: Exemplo de letra uncial em evocação - Documento 09, linha13 


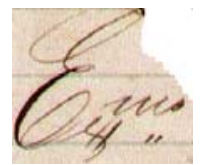

Figura 20: Exemplo de letra uncial em evocação - Documento 07, linha 13

Um dos complicadores da leitura da escrita humanística é a união dos sinais diacríticos, dificultando sua identificação e localização. Também há a diminuição de sinais de pontuação, dada a agilidade da escrita, que contribuiu para o uso das abreviações, das quais trataremos em subitem posterior.

A leve inclinação das letras para a direita, com a incidência de prolongamentos nos contornos superiores e caudais das maiúsculas são características da grafia dos escribas. Verificamos estas ocorrências nos seguintes casos:

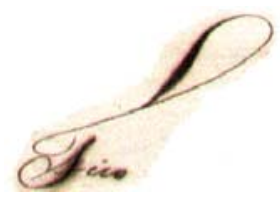

Figura 21: $<$ F $>$ em início de frase - Documento 01, linha 01
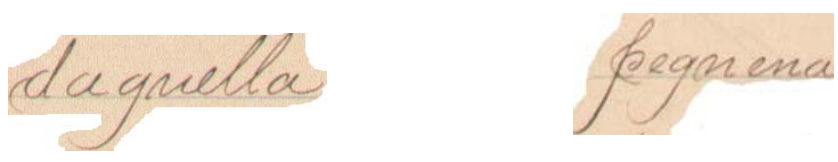

Figura 22: Prolongamento do grafema $<$ q $>$ em meio de palavra e $<$ p $>$ em início de palavraDocumento 10, linhas 07 e 20

Aqui verificamos o prolongamento da haste no grafema $<\mathrm{q}>$. Como se trata de uma escrita marcada pela agilidade e pela união de palavras, os escribas aproveitam o mesmo traçado para prosseguir com a feitura do vocábulo.
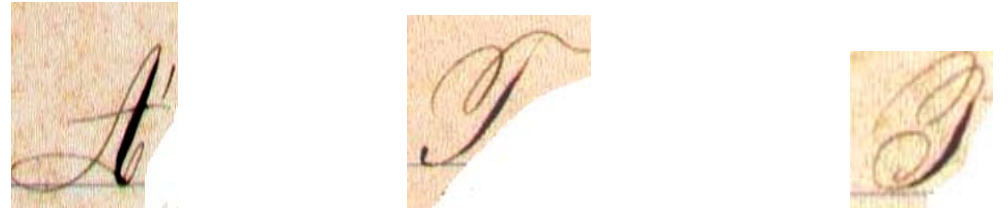

Figura 23 - Doc. 10 - Prolongamento de $<\mathrm{A}>,<\mathrm{T}>$ e $<$ I $>$ em inícios de frase, no primeiro caso, e início de palavra em meio de frase nos dois últimos grafemas. Linhas 04 e 24. 


\subsection{Os escribas e suas habilidades}

No capítulo dois, subitem terceiro, abordou-se a questão da escolaridade dos habitantes de São Paulo, no século XIX, mas resta avaliarmos se os escribas, responsáveis pela confecção dos ofícios assinados pelo administrador, possuíam familiaridade com a escrita.

Conforme Marquilhas, em Faculdade das Letras, a inabilidade das mãos pode "ser reconhecida pela aparência física, constituída pela caligrafia da mão e por particularidades do suporte" (2003, p. 294), tais como o traçado inseguro, a incapacidade de alinhar perfeitamente as letras num regramento ideal, a tendência a conferir às mesmas letras uma aparência desenquadrada, o uso de módulo grande, a ausência quase total de abreviaturas e de elementos de ligação, rigidez e falta de leveza no conjunto.

Com base nos itens levantados supomos que os escribas são hábeis e com base nos seguintes fatores:

1. A insegurança no traçado está ligada à ausência de prolongamentos ou, ainda, a existência destes, mas com exagerado arredondamento. Os documentos analisados não apresentam estas características. Os prolongamentos são lineares e firmes. Os facsímiles 05, 06 e 08, portanto, possuem grande incidência de apoio nas hastes e caudas, porém, a letra é uniforme.

2. Todos os documentos possuem uma margem lateral direita que é seguida do início ao fim do facsímile, havendo proporção entre as margens;

3. Não há características de traçado inseguro ou ainda de desenquadramento nas letras. Todos os documentos apresentam-se uniformemente, embora com diferentes escritas.

O subcapítulo 4.2.1 abordará as características pontuais de cada escriba, bem como a incidência de alógrafos e características de traçado de cada punho.

\subsection{1 \\ Características da escrita: descrição dos aspectos encontrados nos diferentes punhos}

Analisando a grafia dos dez documentos, verificamos que existem oito punhos diferentes responsáveis pela escrita dos facsímiles. 
Tabela 02 - Comparativo entre traçado textual e assinatura

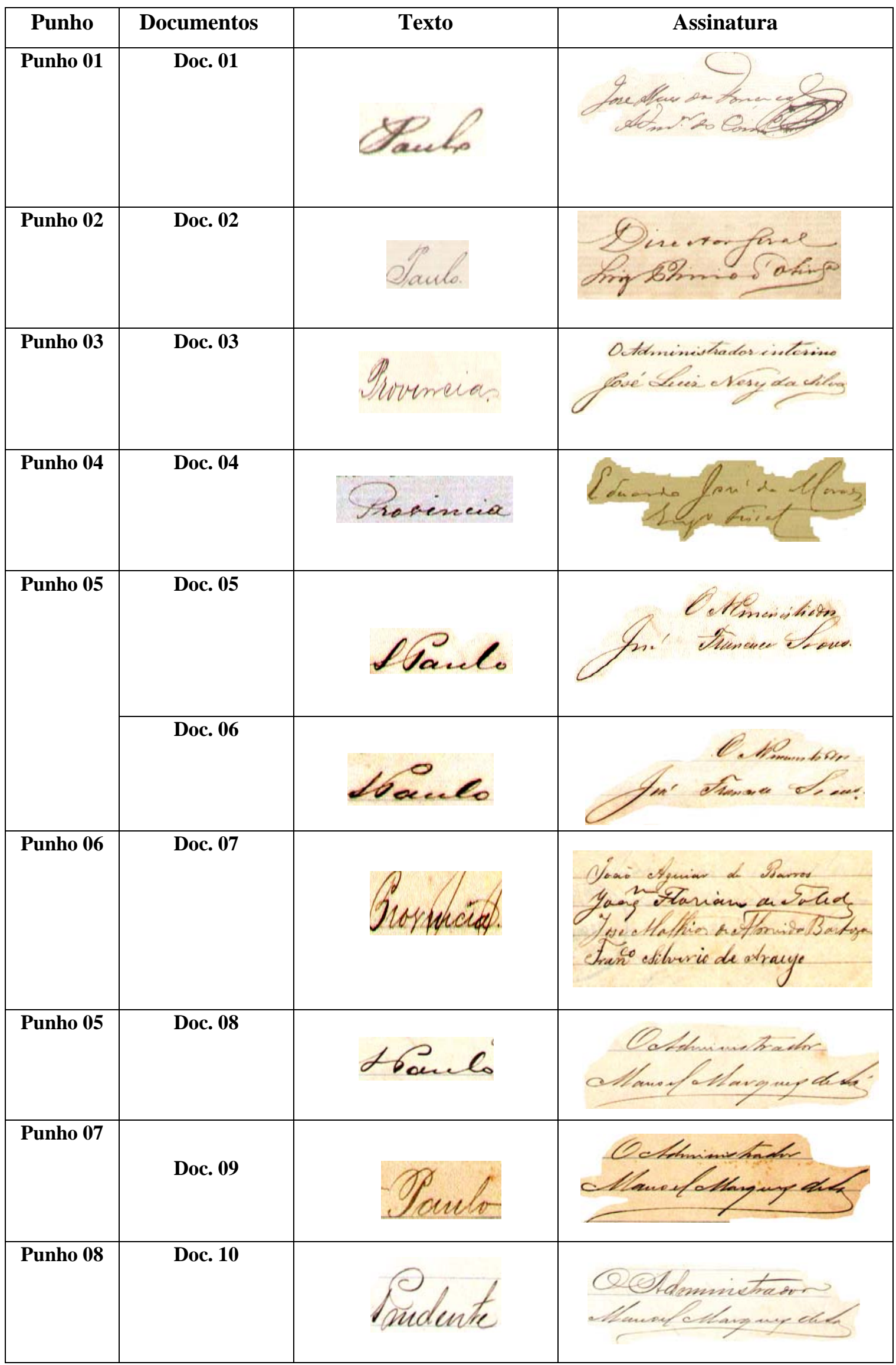


A coluna "assinatura" traz o traçado de letra dos administradores de Correios, visivelmente, diferentes do traçado presente na coluna "texto", o que comprova a apografia dos manuscritos.

A tabela dois possui expressões semelhantes retiradas de todos os documentos, para que pudéssemos comparar o traçado dos grafemas nos diferentes punhos.

Em análise a grafia dos demais manuscritos, verificou-se que há semelhança de traçado nos documentos 5, 6 e 8. Para que se possa verificar as semelhanças elencamos na tabela três, em que há vocábulos que apresentam grafemas cujo traçado se assemelha. Verificamos que os grafemas $<\mathrm{c}>,<\mathrm{f}>$ e $<\mathrm{P}>$ maiúsculo apresentam os mesmos traçados.

Tabela 03 - Semelhanças nos grafemas dos documentos 05, 06 e 08

\begin{tabular}{|c|c|c|}
\hline & Grafema $<$ f $>$ e $<$ c $>$ & Grafema $<$ P $>$ \\
\hline $\begin{array}{l}\text { Documento 05, } \\
\text { p. } 111\end{array}$ & $\begin{array}{l}\text { Yaeto } \\
<\text { facto }>\text {, linha } 15\end{array}$ & $\begin{array}{l}\text { Oavela } \\
<\text { Paula }>\text {, linha } 17\end{array}$ \\
\hline $\begin{array}{l}\text { Documento 06, } \\
\text { p.115 }\end{array}$ & $\begin{array}{l}\text { Precto } \\
<\text { facto }>\text {, linha } 20\end{array}$ & $\begin{array}{l}\text { Pinacensuriga } \\
<\text { Pirassununga }>\text {, linha } 42\end{array}$ \\
\hline $\begin{array}{l}\text { Documento 08, } \\
\text { p.127 }\end{array}$ & <ficar>, linha 17 & $\begin{array}{l}\text { Doec lo } \\
\text { Paulo }>\text {, linha } 42\end{array}$ \\
\hline
\end{tabular}

Os documentos em questão apresentam letras de maior extensão, com poucos prolongamentos. A força empregada na pena ao escrever fez com que as hastes e as caudas dos grafemas tornassem-se mais grossas, causando a sombra no verso do documento.

Concluímos que os documentos partem do mesmo escriba pelas características do $<\mathrm{P}>$ maiúsculo, do traçado do $<\mathrm{f}>$ minúsculo em início de palavra como ocorre em $\langle$ facto $>$ e $<$ ficar $>$, pelas semelhanças do grafema $<0>$ em final de palavra, que podem ser observadas em $<$ facto $>e<$ Paulo $>$ e pela semelhança do traçado do grafema $<\mathrm{c}>$, em meio de vocábulo, observada nos três documentos, nos vocábulos $<$ facto $>$ e $<$ ficar $>$.

Cientes de que há oito punhos, responsáveis pela escritura dos manuscritos passaremos à análise paleográfica. 
Essa tabela é importante para demonstrar-nos que os documentos foram escritos por oito escribas diferentes, apontando a regularidade das atividades e manutenção de oficiais praticando um mesmo ofício durante determinado tempo, confirmando o teor dos decretos que regiam a empresa à época. Além desse fator, a tabela mostra-nos também que os manuscritos eram apógrafos. Verifica-se a diferença entre os traçados presentes na coluna texto e na coluna assinatura. Concluímos que os punhos responsáveis pelas assinaturas dos documentos não são os mesmos responsáveis pela escritura. Diante disto, supomos que todas as cartas da administração eram elaboradas por funcionários, que possivelmente serviam como escribas, sendo de responsabilidade do administrador geral a assinatura do documento.

Tendo em vista, que nossos estudos centram-se nos sinais diacríticos realizaremos nas próximas tabelas levantamento dos traçados e variações de um mesmo diacrítico, incidente no corpus.

$\mathrm{Na}$ língua portuguesa, os diacríticos incidem somente sobre as vogais, consoantes, como no caso de $<$ Sñr $>$ e sob a consoante $<c>$, nos casos em que há cedilha. A tabela comparativa abordará as características de feitura dos sinais diacríticos do corpus.

Em algumas situações o til é a extensão do grafema $<0>$, como em São $<\rho$ le $\delta>$, retirado do documento 10 .

Em outros casos não há a incidência do diacrítico, mas sim um prolongamento do grafema final, como ocorre em concedido <Concedide >, manuscrito 3, linha 16, o que pode confundir o leitor.

Em outros casos há situações em que a haste de determinado grafema confunde-se com a cedilha e, somente, uma análise cuidadosa pode desfazer tais dúvidas.

Em outras situações o diacrítico assemelha-se a um til, mas na realidade é um agudo. A agilidade da escrita suscita a dúvidas e o objetivo do levantamento apresentado na tabela 04 é apresentar os diferentes traçados que elaboram os diacríticos. Tal tabela também será de extrema importância para elencarmos as diferentes formas e locais em que os diacríticos eram apostos, ora sobre vogais, ora sobre consoantes, sendo nosso objetivo central o levantamento quantitativo dos diacríticos, seu emprego e a confirmação, por meio de análise paleográfica, de sua forma real, seja circunflexo, agudo, til, cedilha ou apóstrofo.

Nas colunas em que não houver vocábulos informaremos "não há" . 
Tabela 04 - diacrítico agudo sobre o grafema <a>

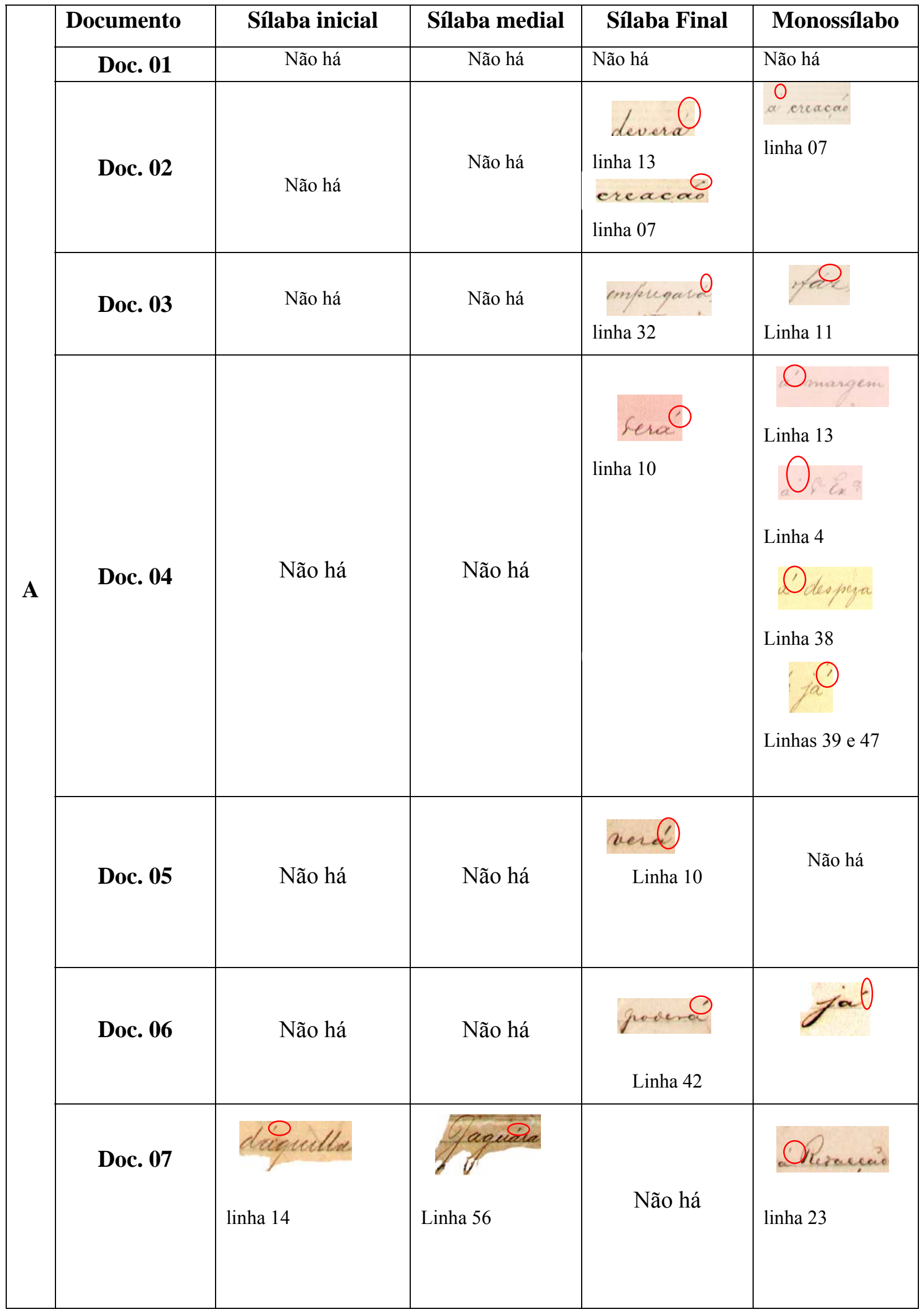




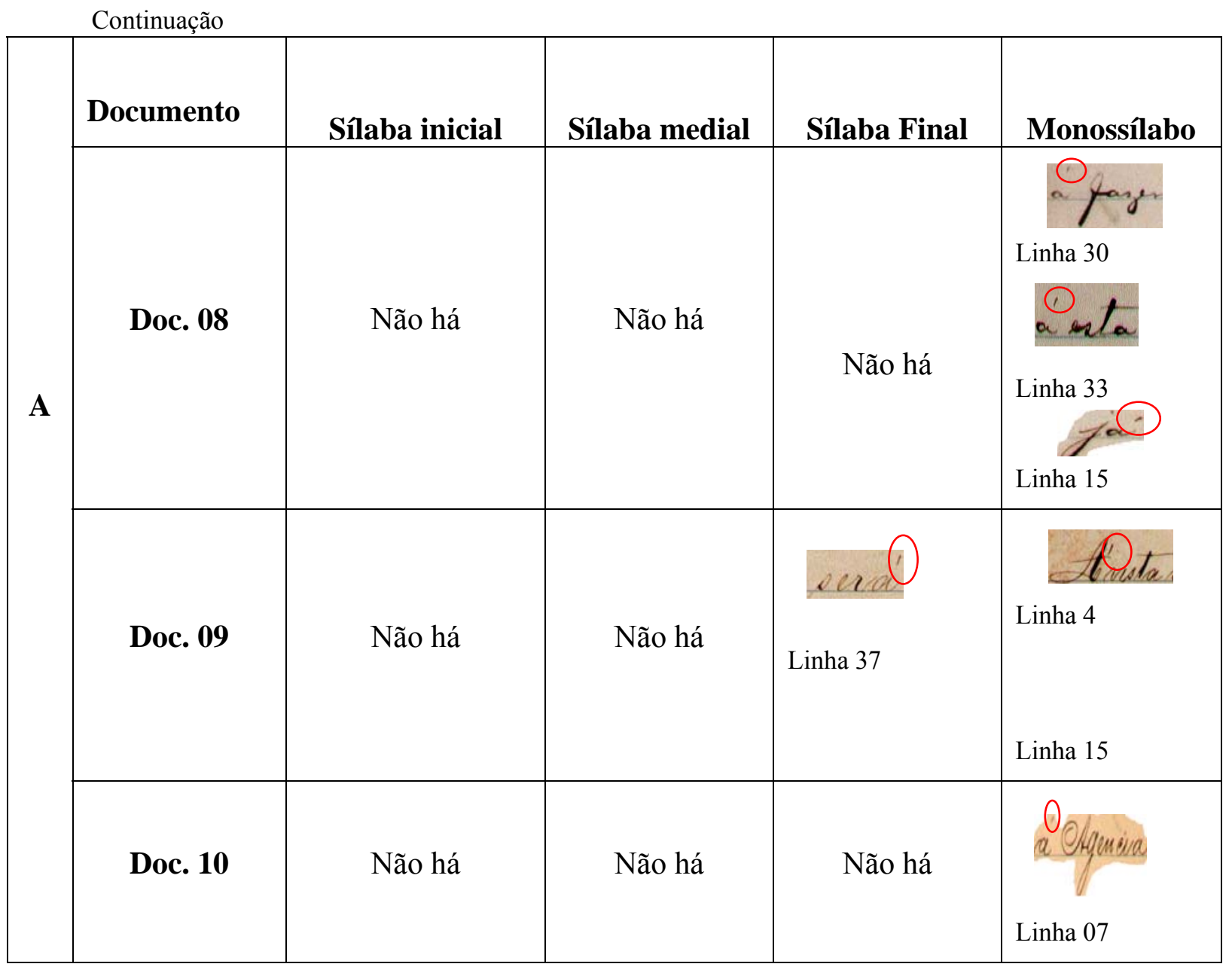

Tabela 05 - diacrítico agudo sobre o grafema $<\mathrm{e}>$

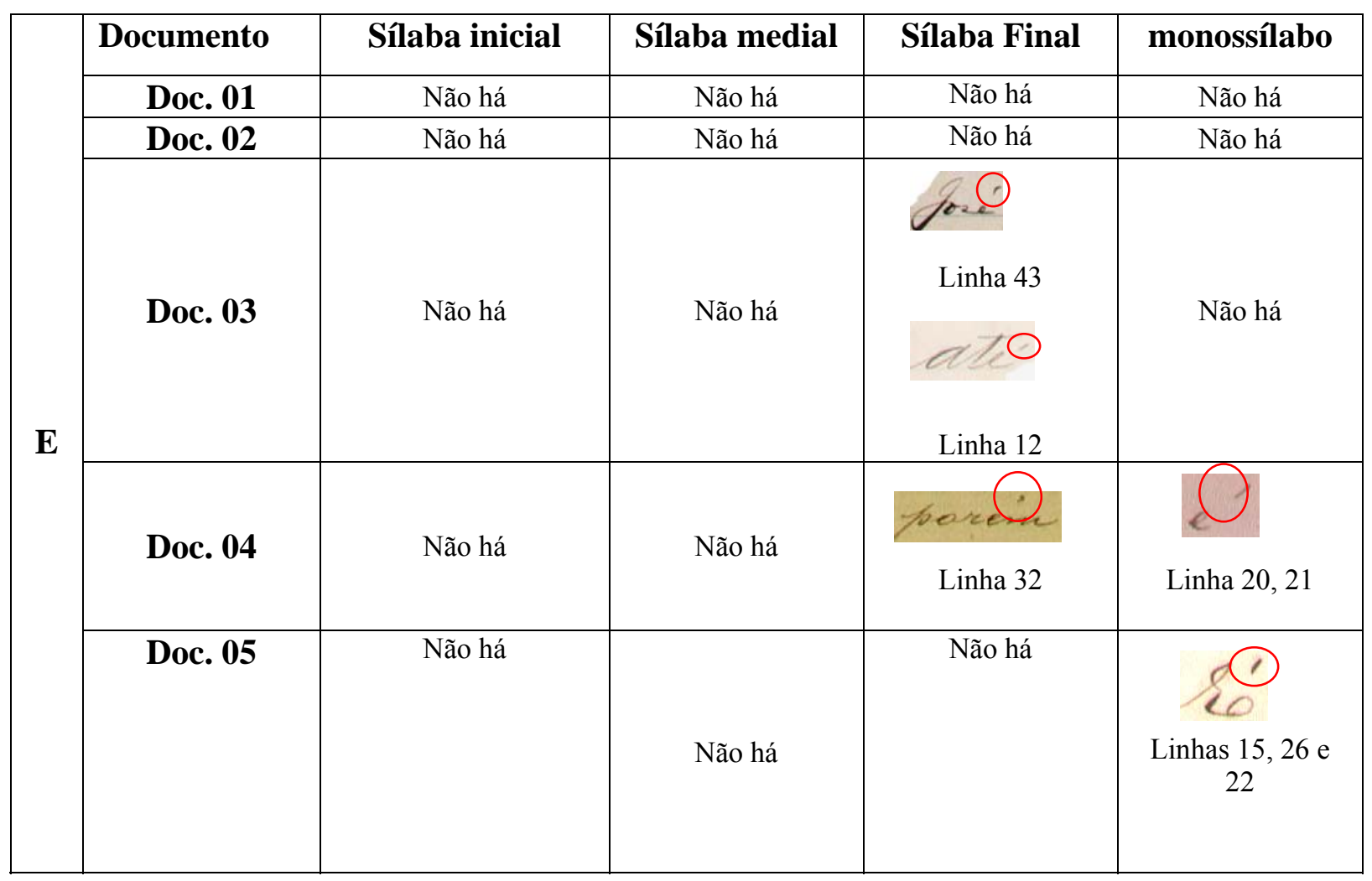




\begin{tabular}{|c|c|c|c|c|c|}
\hline \multirow{6}{*}{$\mathbf{E}$} & Documento & Sílaba inicial & Sílaba medial & Sílaba Final & Monossílabo \\
\hline & Doc. 06 & Não há & Não há & Não há & Não há \\
\hline & Doc. 07 & $\begin{array}{l}\text { dede } \\
\text { Linha } 5 \\
\text { Linha } 18\end{array}$ & Não há & Não há & $\begin{array}{l}O \\
\text { linhas } 24,64,67 \mathrm{e} \\
70\end{array}$ \\
\hline & Doc. 08 & Não há & Não há & Não há & $\begin{array}{l}.0 \\
\text { Linhas } 11,14 \mathrm{e} \\
39\end{array}$ \\
\hline & Doc. 09 & Não há & Não há & Não há & $\begin{array}{l}\text { Linhas } 09,12,13 \\
\text { e } 21\end{array}$ \\
\hline & Doc. 10 & Não há & Não há & Não há & Linha 17 \\
\hline
\end{tabular}

Tabela 06 - diacrítico agudo sobre o grafema $<0>$

\begin{tabular}{|c|c|c|c|c|c|}
\hline \multirow{11}{*}{$\mathbf{O}$} & Documento & Sílaba inicial & Sílaba medial & Sílaba Final & monossílabo \\
\hline & Doc. 01 & Não há & Não há & Não há & Linha 12 \\
\hline & Doc. 02 & Não há & Não há & Não há & Não há \\
\hline & Doc. 03 & Não há & Não há & Não há & Não há \\
\hline & Doc. 04 & Não há & Não há & Não há & Não há \\
\hline & Doc. 05 & Não há & Não há & Não há & Não há \\
\hline & Doc. 06 & $\begin{array}{l}\text { founa } \\
\text { Linha } 46\end{array}$ & Não há & Não há & $\begin{array}{l}\operatorname{co}_{\text {Linha }} 30 \\
\end{array}$ \\
\hline & Doc. 07 & Não há & Não há & Não há & $\begin{array}{l}\text { Linha } 08 \\
\text { Led }\end{array}$ \\
\hline & Doc. 08 & Não há & Não há & Não há & Não há \\
\hline & Doc. 09 & Não há & Não há & Não há & Não há \\
\hline & Doc. 10 & $\begin{array}{l}\text { bode } \\
\text { Linha } 26\end{array}$ & Não há & Não há & Não há \\
\hline
\end{tabular}


Tabela 07 - diacrítico agudo sobre o grafema $<\mathbf{u}>$

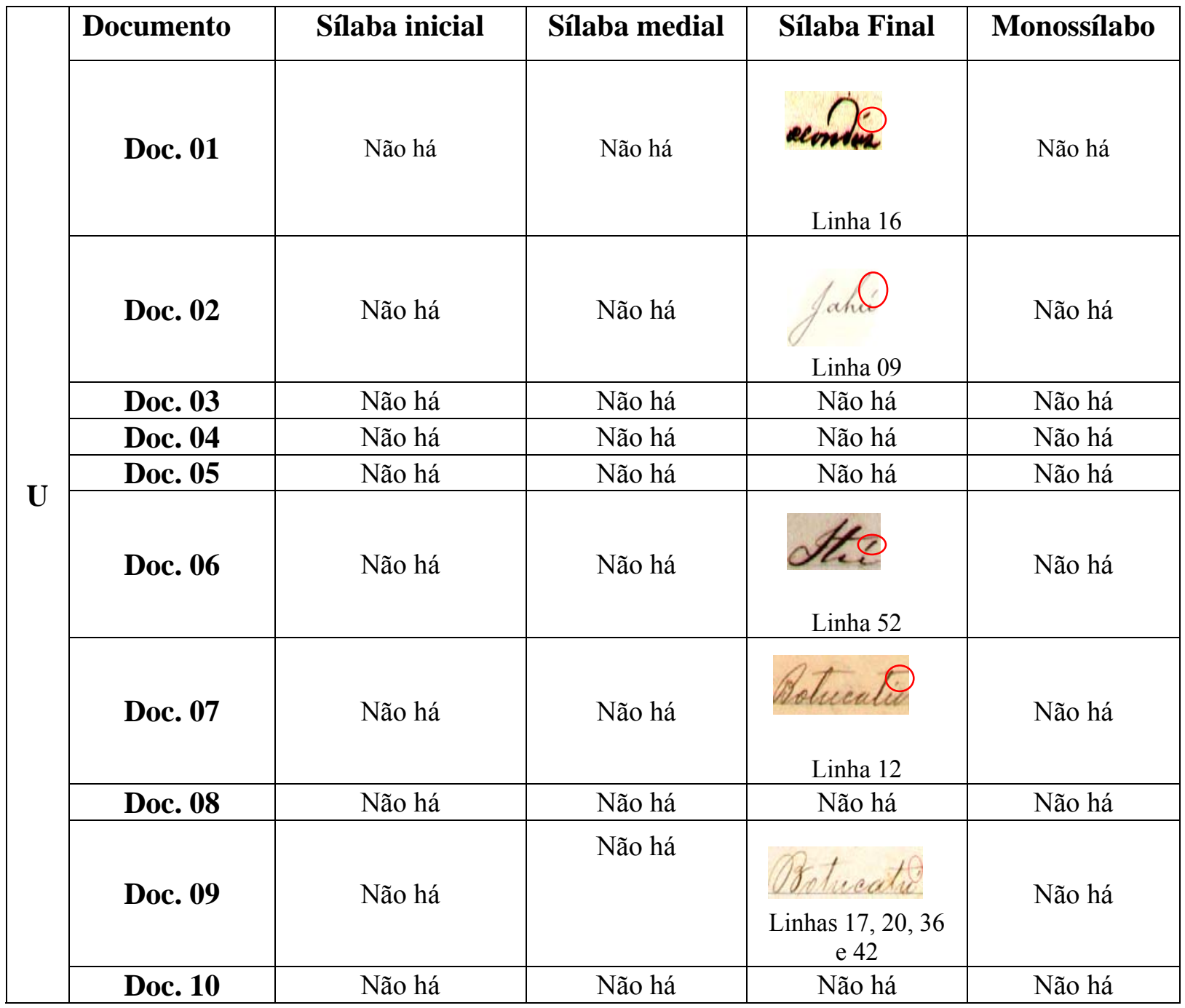

Listamos somente as vogais em que houve incidência de acento agudo. $\mathrm{O}$ corpus não apresentou vocábulos com diacrítico agudo sobre $e$ por tal motivo não há tabela para essa vogal.

Tabela 08 - diacrítico til sobre o grafema $<\mathbf{a}>$

\begin{tabular}{|c|c|c|c|c|c|}
\hline Documento & Sílaba inicial & Sílaba medial & Sílaba Final & Monossílabo \\
\hline A & & & Não há & Não há & Não há \\
\hline Doc. 01 & Não há & Não há & Não há & Não há & Não há \\
\hline Doc. 03 & Não há & Não há & Não há & Não há \\
\hline
\end{tabular}




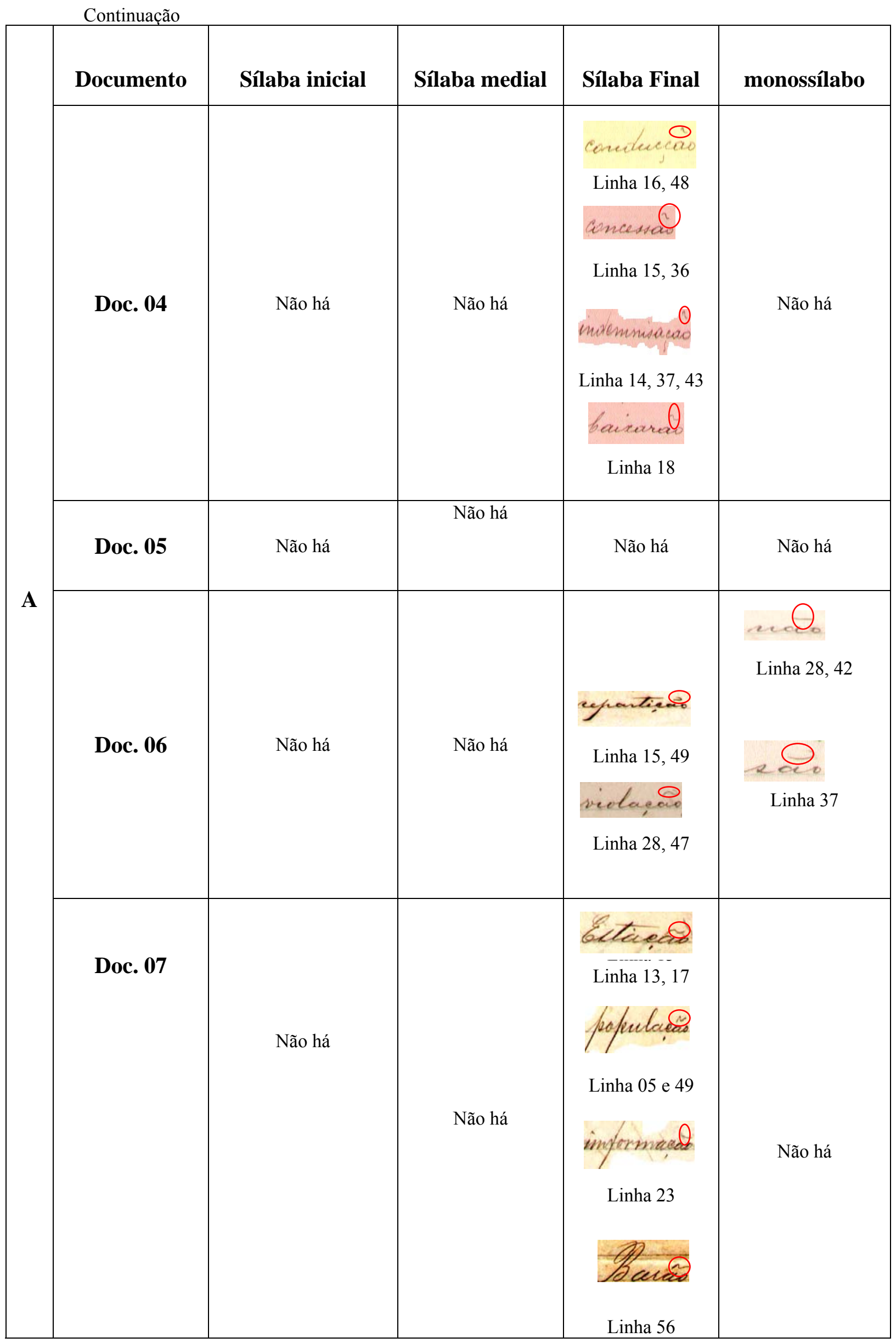


Continuação

\begin{tabular}{|c|c|c|c|c|c|}
\hline & Documento & Sílaba inicial & Sílaba medial & Sílaba Final & monossílabo \\
\hline & Doc. 08 & Não há & Não há & $\begin{array}{c}\text { momease } \\
\text { Linha } 24\end{array}$ & $\begin{array}{l}\overbrace{0} \\
\text { Linhas } 11,26\end{array}$ \\
\hline A & Doc. 09 & Não há & Não há & $\begin{array}{l}\text { Yodere } \\
\text { Linha } 29\end{array}$ & $\begin{array}{l}\text { Linha } 14 \\
\text { Linhas } 5 \text { e } 40 \\
\text { Mare } \\
\text { Linhas } 26,38\end{array}$ \\
\hline & Doc. 10 & Não há & Não há & $\begin{array}{c}\text { celacel } \\
\text { Linha } 22\end{array}$ & $\begin{array}{l}\text { ofde } \\
\text { Linhas } 01,05,19\end{array}$ \\
\hline
\end{tabular}

Tabela 09 - diacrítico til sobre o grafema $<\mathrm{e}>$

\begin{tabular}{|c|c|c|c|c|c|}
\hline Documento & Sílaba inicial & Sílaba medial & Sílaba Final & Monossílabo \\
\hline Doc. 01 & Não há & Não há & Não há & Não há \\
\hline Doc. 02 & Não há & Não há & Não há & Não há \\
\hline Doc. 03 & Não há & Não há & $\begin{array}{c}\text { Linha19 } \\
\text { dlepalo }\end{array}$ & Não há \\
\hline E & Linha 37 & Não há & Não há \\
\hline Doc. 04 & Não há & Não há & Não há & Não há \\
\hline Doc. 05 & Não há & Não há & Não há & Não há \\
\hline Doc. 06 & Não há & Não há & Não há & Não há \\
\hline Doc. 07 & Não há & Não há & Não há & Não há \\
\hline Doc. 08 & & & & \\
\hline
\end{tabular}


Continuação

\begin{tabular}{|c|c|c|c|c|c|}
\hline \multirow{4}{*}{$\mathbf{E}$} & Documento & Sílaba medial & Sílaba medial & Sílaba final & Monossílabo \\
\hline & Doc. 09 & & & $\begin{array}{c}\text { Lalcheacies } \\
\text { Linha } 28\end{array}$ & \\
\hline & & Não há & Não há & 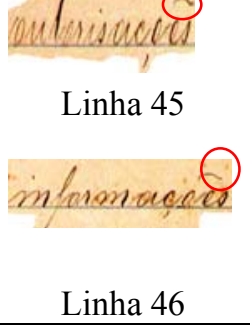 & Não há \\
\hline & Doc. 10 & Não há & Não há & Não há & Não há \\
\hline
\end{tabular}

Tabela 10: diacrítico til sobre o grafema $<0>$

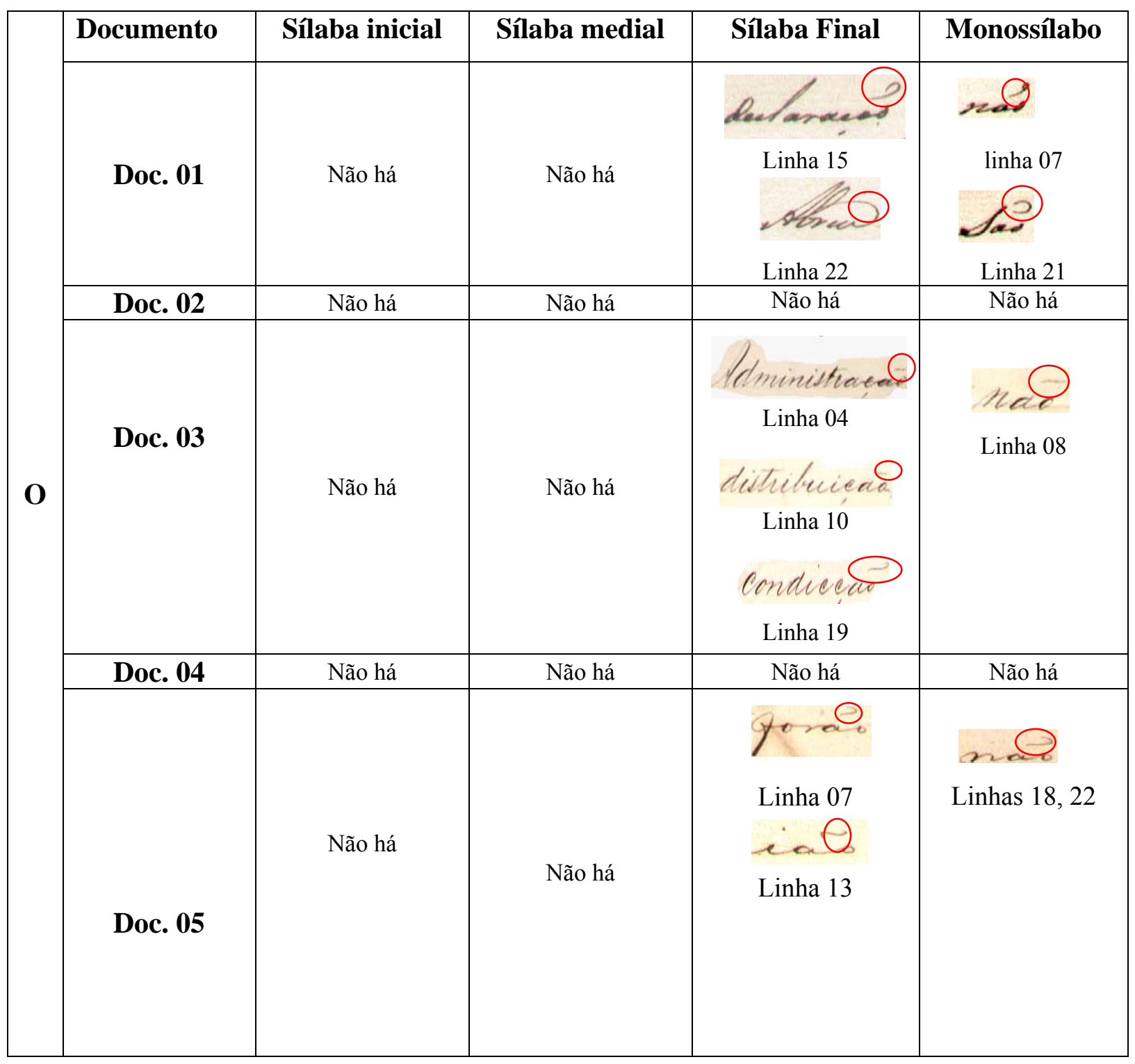




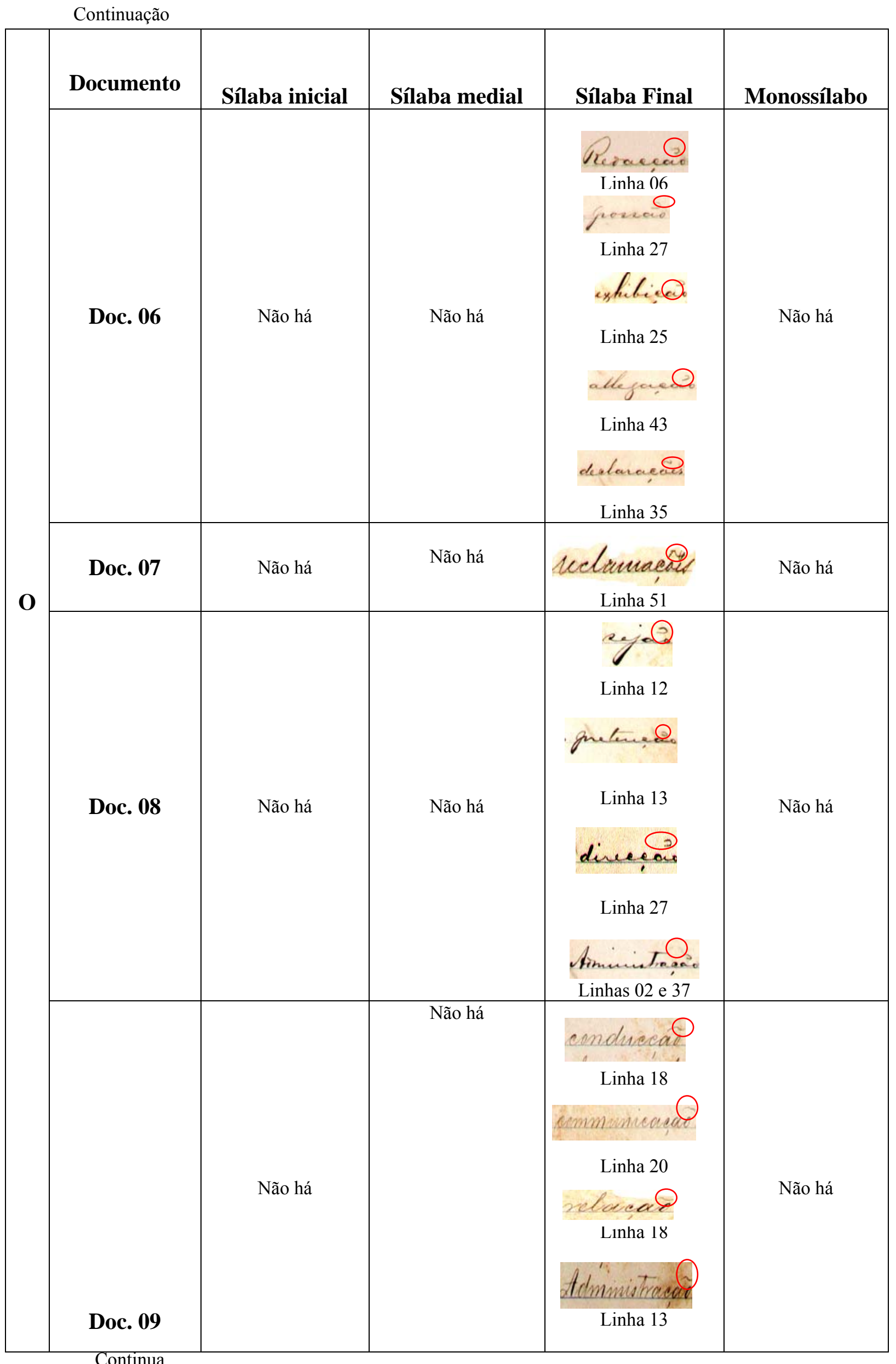




\begin{tabular}{|c|c|c|c|c|c|}
\hline & Documento & Sílaba inicial & Sílaba medial & Sílaba final & Monossílabo \\
\hline O & Doc. 10 & Não há & Não há & $\begin{array}{l}\text { Linha } 5 \\
\text { elawipheaces } \\
\text { Linha } 09 \\
\text { Linha } 03\end{array}$ & Não há \\
\hline
\end{tabular}

Tabela 11: diacrítico til sobre consoante

\begin{tabular}{|c|c|c|c|c|c|}
\hline \multirow{10}{*}{$\begin{array}{l}\stackrel{\mathscr{J}}{\Xi} \\
\text { J } \\
0 \\
0 \\
0\end{array}$} & Documento & $\begin{array}{l}\text { Sílaba } \\
\text { inicial }\end{array}$ & $\begin{array}{c}\text { Sílaba } \\
\text { medial }\end{array}$ & Sílaba Final & Monossílabo \\
\hline & Doc. 01 & Não há & Não há & Não há & Não há \\
\hline & Doc. 02 & Não há & Não há & Não há & Não há \\
\hline & Doc. 03 & Não há & Não há & Não há & Linhas 5,14 e 40 \\
\hline & Doc. 04 & Não há & Não há & Não há & Linha 52 \\
\hline & Doc. 05 & Não há & Não há & Não há & Não há \\
\hline & Doc. 06 & Não há & Não há & Não há & Não há \\
\hline & Doc. 07 & Não há & Não há & Não há & Não há \\
\hline & Doc. 08 & Não há & Não há & Não há & Não há \\
\hline & Doc. 09 & Não há & Não há & Não há & Não há \\
\hline
\end{tabular}

O diacrítico til foi encontrado somente sobre as vogais $a, e, o$ e consoantes. Não foi encontrado sobre o $i$ e $u$ e por tal motivo não elaboramos tabela demonstrativa.

Tabela 12 - Diacrítico apóstrofo e o grafema $<\mathbf{a}>$

\begin{tabular}{|c|c|c|c|c|c|}
\hline & Documento & Sílaba inicial & Sílaba medial & Sílaba Final & Monossílabo \\
\cline { 2 - 6 } & Doc. 01 & Não há & Não há & Não há & Não há \\
\cline { 2 - 6 } A & Noc. 02 & Não há & Não há & Não há \\
\cline { 2 - 6 } & Doc. 03 & $\begin{array}{c}\text { Lrucula } \\
\text { Linha 38 }\end{array}$ & Não há & Não há & Não há \\
\hline
\end{tabular}

Continua 
Continuação

\begin{tabular}{|c|c|c|c|c|c|}
\hline \multirow{4}{*}{ A } & Documento & Sílaba inicial & Sílaba medial & Sílaba Final & Monossílabo \\
\cline { 2 - 6 } & Doc. 04 & Não há & Não há & Não há & Não há \\
\hline Doc. 05 & $\begin{array}{c}\text { Na que Cla } \\
\text { Linha 08 }\end{array}$ & Não há & Não há & Não há \\
\hline Doc. 06 & Não há & Não há & Não há & Não há \\
\hline Doc. 07 & Não há & Não há & Não há & Não há \\
\hline Doc. 08 & Não há & Não há & Não há & Não há \\
\hline Doc. 09 & Não há & Não há & Não há & Não há \\
\hline Doc. 10 & Não há & Não há & Não há & Não há \\
\hline
\end{tabular}

Fim da tabela

Tabela 13 - Diacrítico apóstrofo e o grafema <e >

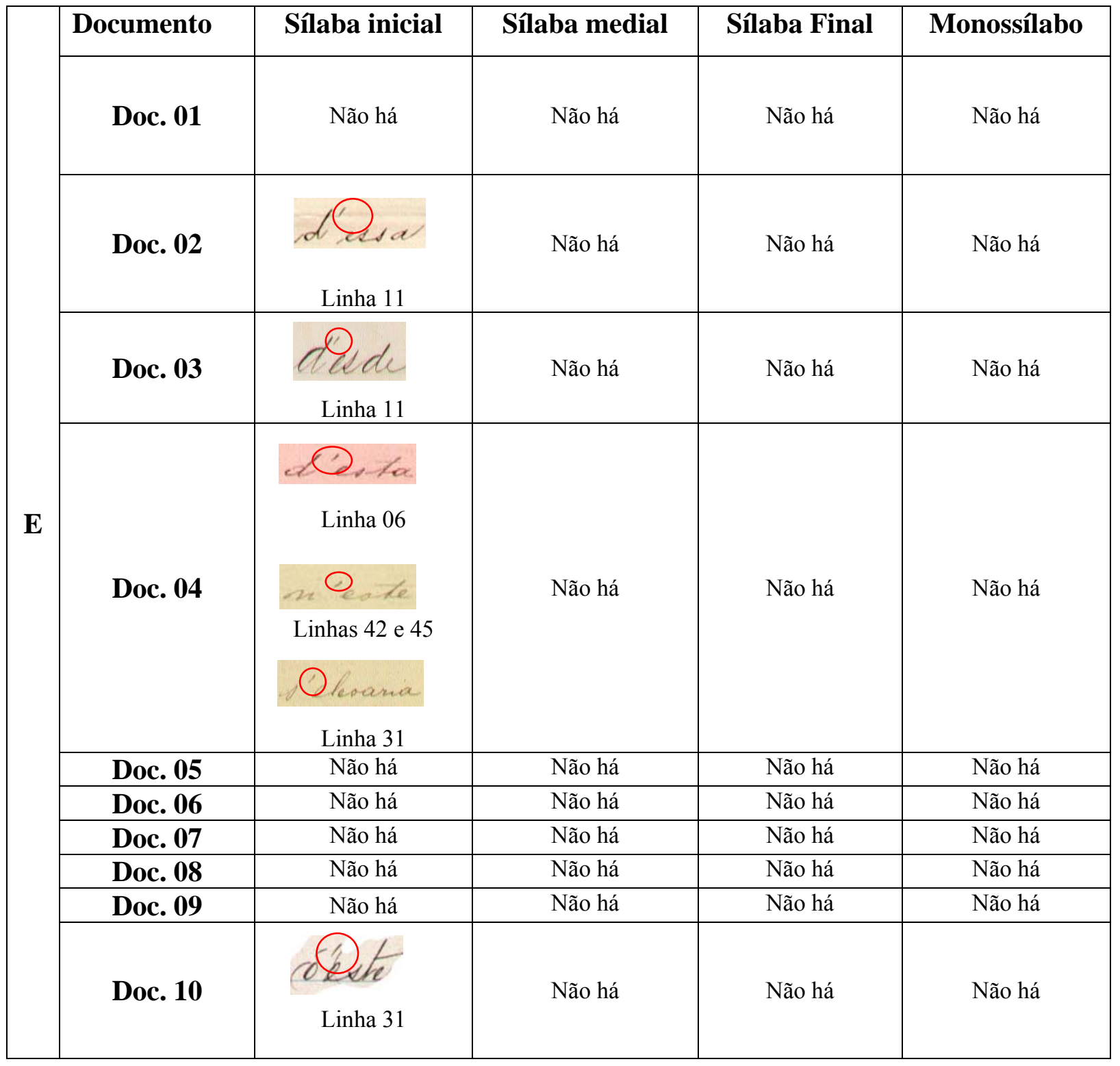


Tabela 14 - Diacrítico apóstrofo e o grafema $<0>$

\begin{tabular}{|c|c|c|c|c|c|}
\hline Documento & Sílaba inicial & Sílaba medial & Sílaba Final & Monossílabo \\
\hline Doc. 01 & Não há & Não há & Não há & Não há \\
\hline Doc. 02 & Não há & Não há & Não há & Não há \\
\hline Doc. 03 & Não há & Não há & Não há & Não há \\
\hline & Oces le & Não há & Não há & Não há \\
\hline Doc. 04 & Linha 31 & & & Não há \\
\hline & Noc. 05 & Não há & Não há & Não há & Não há \\
\hline Doc. 06 & Não há & Não há & Não há & Não há \\
\hline Doc. 07 & Não há & Não há & Não há & Não há & Não há \\
\hline Doc. 08 & Não há & Não há & Não há & Não há \\
\hline Doc. 09 & Não há & Não há & Não há & Não há \\
\hline Doc. 10 & & &
\end{tabular}

O apóstrofo ocorreu na supressão das vogais $a$, $e$ e $o$. Não foi encontrado no corpus em vocábulos com início $i$ e $u$.

Tabela 15 - Diacrítico circunflexo sobre o grafema $<\mathrm{e}>$

\begin{tabular}{|c|c|c|c|c|}
\hline Documento & Sílaba inicial & Sílaba medial & Sílaba Final & Monossílabo \\
\hline Doc. 01 & Não há & Não há & Não há & Não há \\
\hline Doc. 02 & Não há & Não há & Não há & Não há \\
\hline Doc. 03 & Não há & Não há & Não há & Não há \\
\hline Doc. 04 & Não há & Não há & Não há & Não há \\
\hline Eoc. 05 & Não há & Não há & Não há & Não há \\
\hline Doc. 06 & Não há & Não há & Não há & Não há \\
\hline Doc. 07 & Não há & Não há & Não há & Não há \\
\hline Doc. 08 & Não há & Não há & Não há & Não há \\
\hline Doc. 09 & Não há & darera & Não há & d \\
\hline Doc. 10 & Não há & Não há & Não há & Linha 32 \\
\hline
\end{tabular}


Tabela 16 - Diacrítico circunflexo sobre o grafema $<0>$

\begin{tabular}{|c|c|c|c|c|c|}
\hline \multirow{11}{*}{$\mathbf{O}$} & Documento & Sílaba inicial & Sílaba medial & Sílaba-Final & Monossílabo \\
\hline & Doc. 01 & Não há & Não há & Não há & Não há \\
\hline & Doc. 02 & Não há & Não há & Não há & Não há \\
\hline & Doc. 03 & Não há & $\begin{array}{l}\text { padas } \\
\text { Linha } 29\end{array}$ & Não há & Não há \\
\hline & Doc. 04 & Não há & Não há & Não há & Não há \\
\hline & Doc. 05 & Não há & Não há & Não há & Não há \\
\hline & Doc. 06 & $\begin{array}{l}f^{\ominus} \text {-a } \\
\text { Linha } 09\end{array}$ & Não há & Não há & Não há \\
\hline & Doc. 07 & Não há & Não há & Não há & Não há \\
\hline & Doc. 08 & Linha 10 & Não há & Não há & Não há \\
\hline & Doc. 09 & Não há & Não há & Não há & Não há \\
\hline & Doc. 10 & Não há & Não há & Não há & Não há \\
\hline
\end{tabular}

O circunflexo foi encontrado sobre as vogais $e$ e $o$, somente. No corpus não houve ocorrência de uso do circunflexo sobre $a$.

Tabela 17 - Diacrítico cedilha e o grafema <a>

\begin{tabular}{|c|c|c|c|c|c|}
\hline \multirow{3}{*}{ ÇA } & Documento & Sílaba inicial & Sílaba medial & Sílaba Final & Monossílabo \\
\hline & Doc. 01 & Não há & Linha 5 & Linha 15 & Não há \\
\hline & Doc. 02 & Não há & Não há & $\begin{array}{c}\text { ereagóo } \\
\text { Linha } 07\end{array}$ & Não há \\
\hline
\end{tabular}

Continua 
Continuação

\begin{tabular}{|c|c|c|c|c|c|}
\hline \multirow{2}{*}{\multicolumn{2}{|c|}{\begin{tabular}{|r|r|} 
Documento \\
\\
Doc. 03
\end{tabular}}} & Sílaba inicial & Sílaba medial & Sílaba Final & Monossílabo \\
\hline & & Não há & Não há & 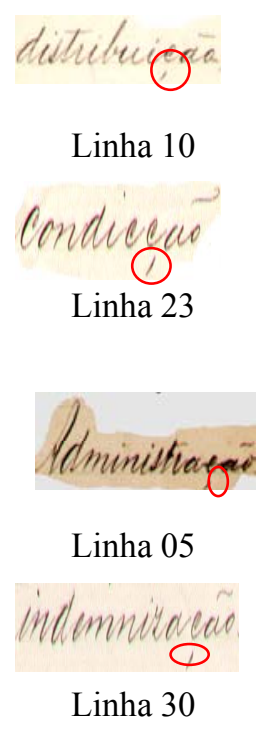 & Não há \\
\hline \multirow{4}{*}{ ÇA } & Doc. 04 & Não há & $\begin{array}{l}\text { langada } \\
\text { Linha } 12\end{array}$ & Não há & Não há \\
\hline & Doc. 05 & Não há & Não há & Não há & Não há \\
\hline & Doc. 06 & Não há & Não há & $\begin{array}{l}\text { Redaceas } \\
\text { Linhas } 07 \text { e } 26 \\
\text { upartisas, } \\
\text { Linha } 15 \text { e } 49 \\
\text { eshibigas } \\
\text { Linha } 25 \\
\text { sidagow } \\
\text { Linhas } 28 \text { e } 47\end{array}$ & Não há \\
\hline & Doc. 07 & Não há & Não há & 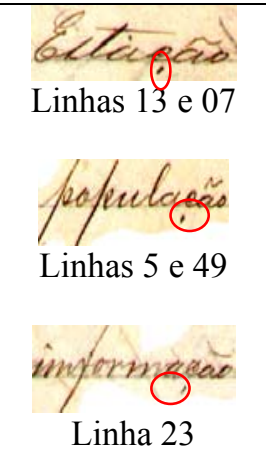 & Não há \\
\hline
\end{tabular}


Continuação

\begin{tabular}{|c|c|c|c|c|c|}
\hline \multirow{4}{*}{ ÇA } & Documento & Sílaba inicial & Sílaba medial & Sílaba Final & monossílabo \\
\hline & Doc. 08 & Não há & Não há & $\begin{array}{c}\text { Laeno } \\
\text { Linha } 7 \\
\text { dise. O } 0 \\
\text { Linha } 27\end{array}$ & Não há \\
\hline & Doc. 09 & Não há & Não há & $\begin{array}{l}\text { madenga } \\
\text { Linha } 14 \\
\text { segmomeg } \\
\text { Linha } 27\end{array}$ & Não há \\
\hline & Doc. 10 & Não há & Não há & $\begin{array}{l}\text { Linha } 04 \\
\text { muntiga } \\
\text { Linha } 6\end{array}$ & Não há \\
\hline
\end{tabular}

Fim da tabela

Tabela 18 - Diacrítico cedilha e o grafema <e>

\begin{tabular}{|c|c|c|c|c|c|}
\hline \multirow{7}{*}{ Doc. 01 } & Socumento & Sílaba inicial & Sílaba medial & Sílaba Final & Monossílabo \\
\hline \multirow{6}{*}{ ÇE } & Não há & Ninha 23 & & Não há & Não há \\
\cline { 2 - 6 } & & Não há & Não há & Não há \\
\hline & Doc. 02 & Não há & Não há & Não há & Não há \\
\hline & Doc. 03 & Não há & Não há & Não há & Não há \\
\hline Doc. 04 & Não há & Não há & Não há & Não há \\
\hline Doc. 05 & Não há & Não há & Não há & Não há \\
\hline Doc. 06 & Não há & Não há & Não há & Não há \\
\hline Doc. 07 & Não há & Não há & Não há & Não há \\
\hline Doc. 08 & Não há & Não há & Não há & Não há \\
\hline Doc. 09 & Não há & Não há & Não há & Não há & Não há \\
\hline
\end{tabular}


Tabela 19 - Diacrítico cedilha e o grafema <0>

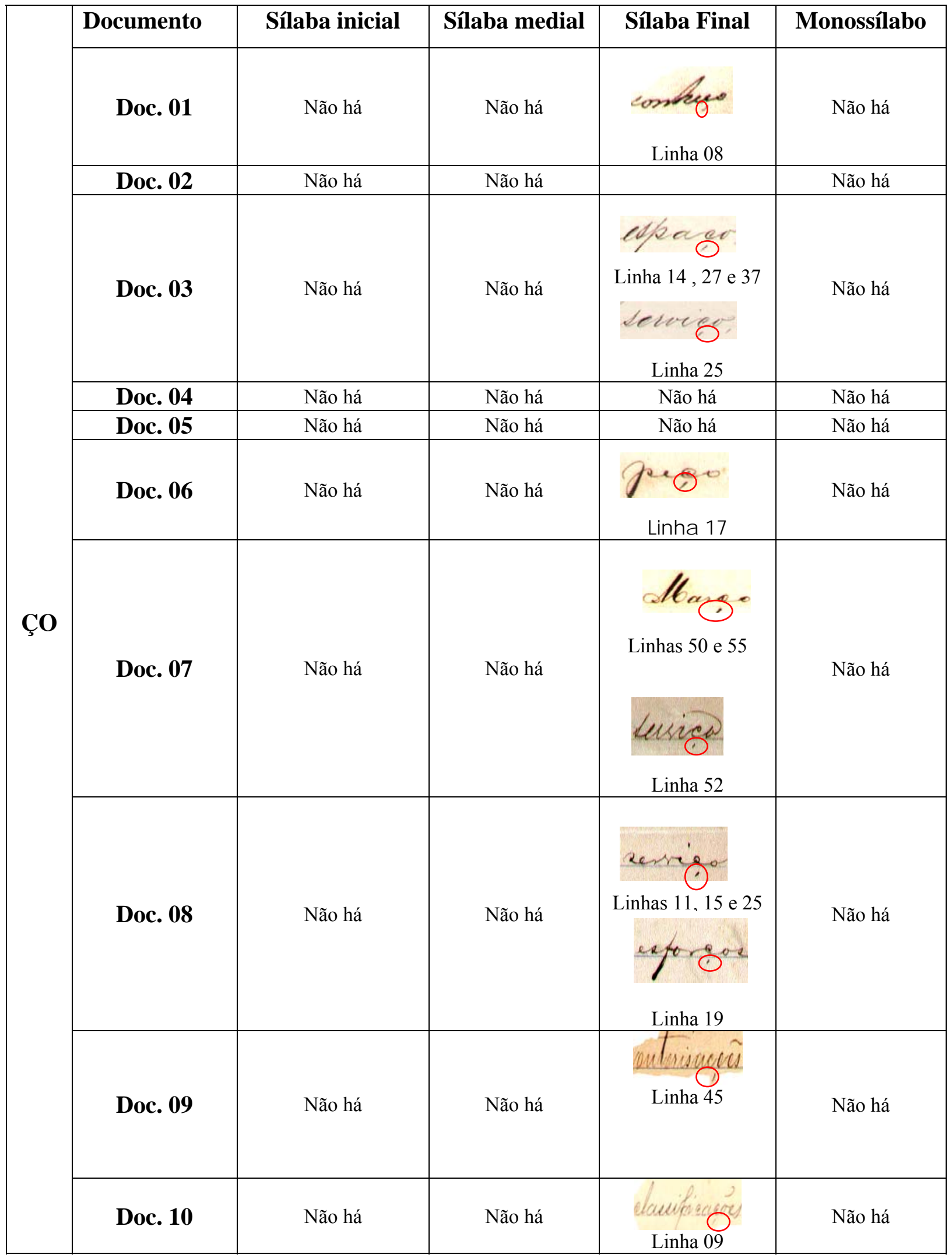


No corpus não foi encontrado $c ̧$ antecedendo as vogais $i$ e $u$.

Para melhor visualização de todos os diacríticos circulamos em vermelho cada um, de acordo com a proposta de cada tabela. Cada linha das tabelas equivale a um documento e abaixo de cada vocábulo consta o número da linha em que está localizado.

\subsection{Abreviaturas}

Em todos os documentos analisados há a presença de abreviaturas. A maior incidência é sobre os pronomes de tratamento, existentes nas evocações e despedidas dos ofícios.

Em estudo acerca dos tratamentos formais empregados em documentos oficiais, Silveira (2005, p.192) aborda a questão da redução das fórmulas de tratamento em documentos dessa natureza. No corpus da Administração Geral dos Correios todas as ocorrências apresentam evocações e despedidas de forma abreviada. Além do domínio da escrita, neste caso, o uso das abreviaturas relaciona-se a formalidade exigida pelo documento. As formas abreviadas conferem uma formalidade maior do que se empregados de maneira completa.

As abreviaturas em documentos oficiais existem até os dias atuais e são amplamente utilizadas, em formatos semelhantes aos empregados no século XIX.

Ainda hoje, empregamos em ofícios abreviaturas nas evocações, no entanto, em menor grau, o que reduz o tamanho da fórmula de tratamento de $\mathrm{Ill}^{\mathrm{mo}} \mathrm{Exc}^{\mathrm{mo}} \mathrm{Snr}^{\mathrm{o}}$ para $\mathrm{Il}^{\mathrm{mo}} \mathrm{Sr}$.

No entanto, atualmente, segundo Higounet (2004, p. 170) “o uso de abreviações na escrita corrente, seja em notas pessoais, seja na correspondência, não corresponde mais a regras gerais. Uma pesquisa mostraria logo que a suspensão e a contração são os dois modos mais frequentemente utilizados”. Apoiando-nos na escrita de ofícios tal afirmação é verídica e confirma a empregabilidade de abreviaturas em correspondências oficiais.

A escrita processada e a habilidade dos escribas são fatores que promovem o uso das abreviaturas. Historicamente, as abreviaturas possuem características bem peculiares e no século XIX seguiam padrões e normas pré-estabelecidas em manuais de boa escrita.

Dentre esses, citamos o Novo secretário português (1860), que apresenta regras de como escrever bem, respeitando as normas de boa escrita do século XIX. As abreviaturas encontradas nos documentos do corpus remetem aos modelos da época.

Atualmente, as abreviaturas são recorrentes em ofícios, como nos manuscritos de nosso corpus. 
As abreviaturas têm como objetivo principal a agilização da escrita, visando a economia de tempo e de material, sendo amplamente utilizada na escrita processada como parte do processo deste tipo de escrita. Segundo Higounet (2004, p. 145)

[...] o uso de abreviações e de sistemas de notação abreviada, em vista de uma maior rapidez de registro da palavra, remonta a Antiguidade grega e romana. As inscrições latinas, a partir do século II a.C., já utilizam siglas, letras iniciais representando palavras, letras coladas $[\ldots]$

Segundo Berwanger \& Leal (2008, p. 92) as abreviaturas se subdividem da seguinte forma: siglas, suspensão ou apócope, contração ou sincope, letras sobrescritas e notas tironianas ou taquigrafia. Nos documentos analisados não constam notas tironianas e abordaremos, somente, os quatro primeiros itens.

Abreviaturas por suspensão ou apócope: ocorre quando parte da palavra desaparece, permanecendo, somente, a letra ou sílaba inicial da palavra original. No corpus foram encontradas as seguintes abreviaturas:
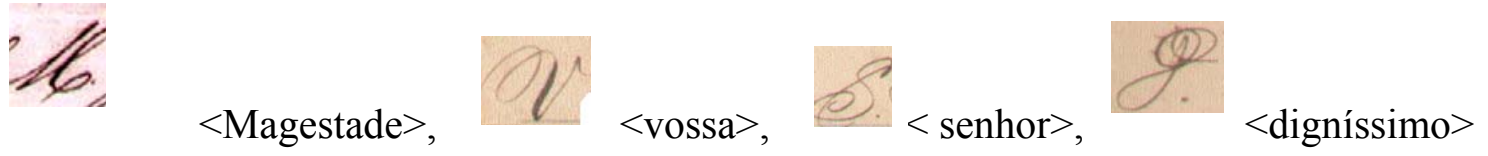

são ocorrências de abreviaturas por suspensão ou apócope.

$<$ Vossa $>$ será encontrada em quase todo o corpus, com exceção, do documento 10. $<$ São $>$ será encontrada nos documentos 05, linha 37; 06, linhas 10 e 53; 10, linha 27 e documento 08 , linha 42 . $<$ D. $>$ foi encontrado nos documentos 03 , linha $41 ; 04$, linha $54 ; 07$, linha 57 e documento 10 , linha $31 .<\mathrm{M}>$ foi encontrado somente no documento 01 .

Abreviatura por contração ou síncope: esta forma de abreviatura é realizada com a supressão da parte central da palavra, permanecendo a letra ou sílaba inicial e final.

Encontramos as seguintes abreviaturas:

$<$ Senhor $>$ A abreviatura de senhor foi encontrada nos documentos 01, linha 21; documento 02, linhas 06 e 18; documento 03, linhas 03, 05 e 40; 04, linhas 03, 11 e 52; 05, linhas 03 e 36; 06, linhas 03, 08 e 52; documento 07, linhas 03 e 56; 08, linhas 03 e 41 e documento 09, linhas 03 e 49.

$<$ Reis $>$ foi encontrado no documento 04 , linha 31 
Abreviatura com letras sobrescritas: este tipo de abreviatura possui as mesmas características da abreviatura por contração, porém, a parte final da palavra mantém-se sobreposta à parte inicial. Exemplos:

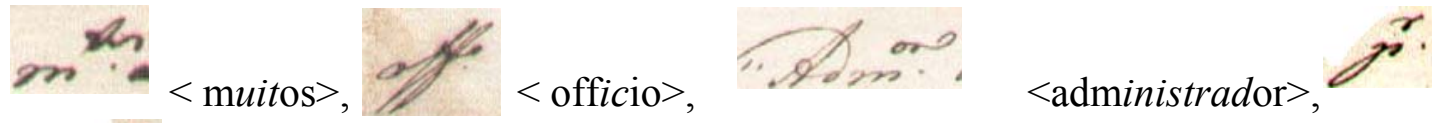

$<$ por $>, \quad$ ? annos $>$ presentes no documento 01, respectivamente nas linhas 19, 01, $21 \mathrm{e}$ 19.

Foram encontradas formas diferenciadas de abreviar o mesmo vocábulo com letras sobrescritas, como em $<$ Illustrissimo>, encontrados nos documentos 01, linha 21; 03, linhas 03 e 40; 04, linhas 03 e 52; 05, linhas 03 e 36; 06, linhas 03 e 52; 07, linhas 03 e

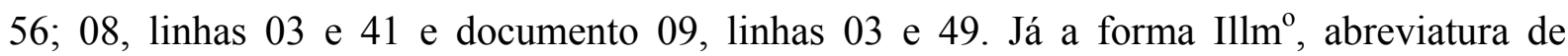
$<$ illustrissimo $>$, diferente das demais, foi encontrado nos documentos 02 , linhas 03 e 18; 07, linhas 03 e 56.

Variação semelhante ocorreu com a abreviatura de <excellentissimo $>$. A forma

foi encontrada nos documentos 09, linhas 03 e 49; 07, linhas 03 e 56; 04, linhas 03 e 52 e 02 , linhas 04 e 18. Já Com foi encontrado nos documentos 08 , linhas 03 e $41 ; 06$, linhas 03 e 52; 05, linhas 03 e 06.

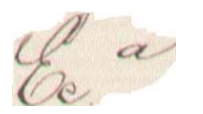

$<$ excellencia>, encontrado nos documento 02, linha 09; 03, linha 39; 04, linha 3;05, linhas 10 e 35; 06, linha 18;08, linha 04 e 09, linha 7 apresenta a última vogal sobreposta, no entanto, o documento 07 aponta a abreviatura $6 \%$ <excellencia $>$ com a última sílaba sobreposta. É a única ocorrência com estas características em todo o corpus.

Em verificação aos demais documentos constatamos que a elevação da última sílaba dos vocábulos <excellentissimo $>$ e <illustrissimo $>$ em detrimento da elevação, somente, da última vogal deve-se a opção do escriba uma vez que todos os manuscritos são do português do século XIX. Conforme tabela 02, os manuscritos 02, 04, 07 e 09 não pertencem ao mesmo escriba, o que nos reforça a hipótese de aleatoriedade do uso. 
Se verificarmos a freqüência de aparição de ambos os tratamentos perceberemos que em todas as ocorrências eles estão presentes na mesma frase, ou seja, como parte de um só tratamento de cortesia, obedecendo a formato padrão de elaboração de ofícios.

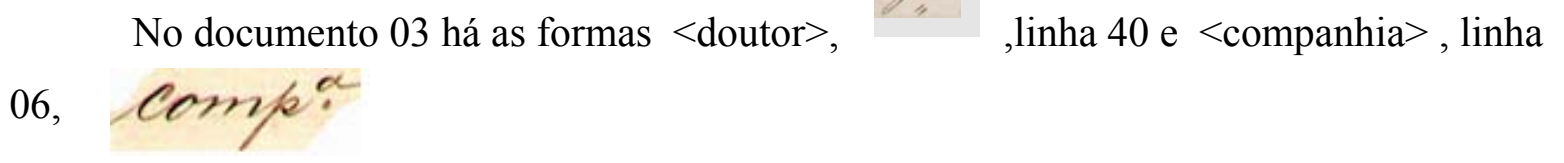

No manuscrito 04 há a abreviatura $<$ digníssimo $>$, linha 54. Diferente da forma encontrada nos documentos 03 e 07 , linhas 41 e 57, cuja forma de abreviatura é a apócope.

A abreviatura $22^{:}<$numero $>$apareceu somente no documento 04, linha 19.

Abreviações numéricas: este tipo de abreviação é composta por números e letras e caracteristicamente sobreposta. Embora, tenham as características das abreviaturas sobrepostas, optamos por relacioná-las separadamente devido ao seu desenvolvimento e da existência de números, o que resultou em sua denominação. As ocorrências foram encontradas nos documentos 08 e 10.

No primeiro manuscrito a ocorrência é a abreviatura

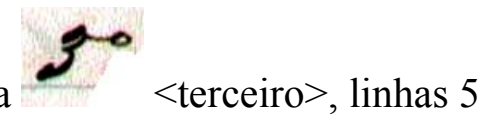

e 21 e no documento 10 as abreviaturas
$<$ segunda $>$, linha 28 .

Há ainda as abreviaturas com sinais especiais e letras inclusas, cujas características particulares, relacionadas com a supressão de parte da palavra abreviada são uma caracterização própria de abreviatura. Não houve ocorrência destes sinais abreviativos nos documentos analisados. 


\section{Sinais de Pontuação e Sinais Diacríticos: uma abordagem filológica}

Neste capítulo levantaremos a incidência dos sinais diacríticos e de pontuação em todo o corpus, bem como suas funções no contexto escrito nos documentos do século XIX. Elencaremos os tipos e funções destes sinais, para então analisarmos, mais detalhadamente, a função dos sinais diacríticos; dando destaque ao o acento agudo como marcação prosódica de entonação e seu emprego no decorrer do século XIX. Tais explanações serão realizadas a partir do sexto capítulo.

Para a execução desse capítulo, procurou-se - em gramáticas portuguesas e brasileiras - informações sobre o uso e emprego dos sinais diacríticos.

Contextualizamos o material do corpus com estudos contemporâneos sobre o assunto, na tentativa de buscarmos os indícios da mudança linguística que motivou a permanência de alguns sinais diacríticos e a exclusão de outros, em diferentes vocábulos.

\subsection{Sinais de Pontuação}

A pontuação consiste na utilização de sinais gráficos que determinam o grau de coesão entre as unidades do texto. Segundo Bluteau (1712), a pontuação era composta por "pontos, vírgulas, \& certos sinaes, \& notas", conforme descrito:

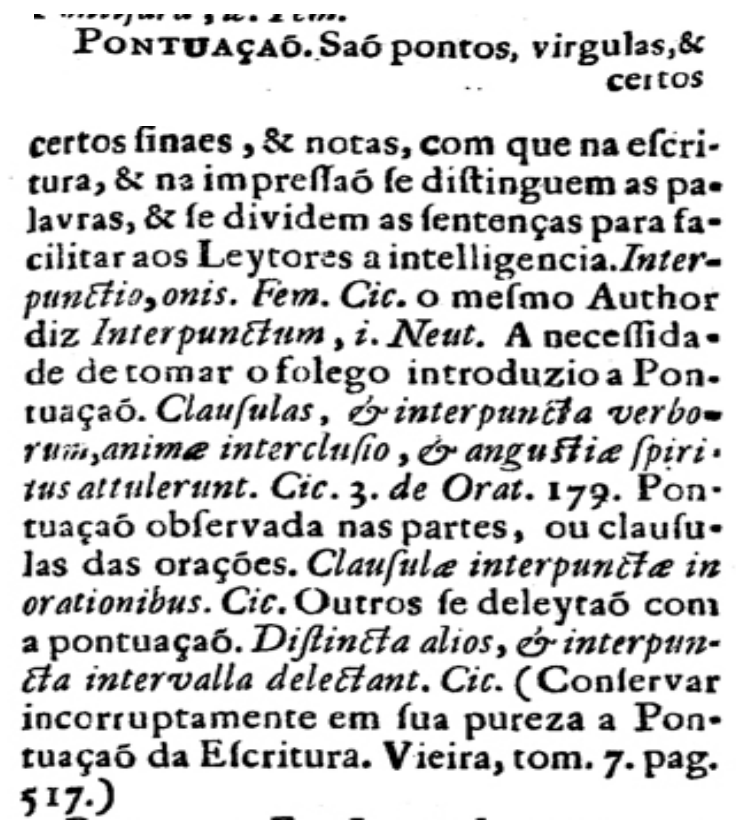

Figura 24 - Definição de Bluteau para Pontuação 
Complementando a definição de Bluteau, Julio Ribeiro (1881), em sua Grammatica portugueza, não somente define pontuação como também a distingue dos diacríticos. Afirma que a "pontuação é para a syntaxe o que a accentuação é para a lexeologia: a accentuação faz distinguir a significação das palavras isoladas; a pontuação discrimina o sentido dos membros, clausulas e sentenças do discurso" (p. 274).

Os sinais de pontuação encontrados nos dez documentos analisados são: o ponto final ( ) , como em < alivgstecalú. >, a vírgula ('), a exemplo apontamos

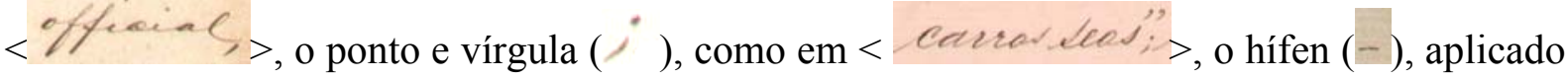
em $<$ odminie- tradors, os traços duplos, como em $<$ ahomde (nomile) como

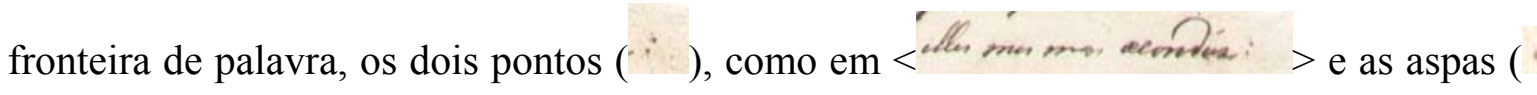
3 ), que encontramos em $<$ thio Branco $>$

O ponto final foi encontrado em todos os documentos para demarcar o término de orações e a finalização de abreviaturas. Conforme, Ribeiro (1881, p.276), é usado "para fechar a sentença (...), nas abreviações (...)", o que confirma o emprego do referido ponto nos documentos do corpus.

A vírgula foi definida por Moraes (1813) como:

\section{VIRGULA, f. f. final ortografico, que di- vide os membros, $e$ incidentes do periodo, ou traze.}

Figura 25 - Definição de Moraes para Vírgula

Esse sinal de pontuação foi utilizado em todos os documentos, porém, ocupando funções distintas, a saber:

> Separação de orações coordenadas assindéticas como identificamos nos documentos 01, linha 12 e documento 02 , linhas 8 e 19,

$>$ Separação de orações coordenadas sindéticas, como encontrado nos documentos 01 , linha 08 e documento 03 , linha 09 ;

Demarcação de orações subordinadas, como encontrado nos documentos 01, linha 14 e documento 02 , linhas 14 ; 
$>$ Isolamento de expressões explicativas, como ocorreu nos documentos 03, linha 30 e documento 04 , linha 21 ;

$>$ Enumeração de informações, como no documento 03, linha 12 e documento 06, linha 25 ;

$>$ Separação de aposto, que verificamos nos documentos 01, linhas 02, 03 e 32 e documento 04, linhas 12 e 29.

Separação entre local e data.

O ponto e vírgula tem como função "separar preposições similhantes e de alguma extensão, sobretudo si taes preposições compõe-se de partes já divididas pela vírgula”, como afirma Ribeiro (1881, p. 276). O sinal foi utilizado em alguns documentos da seguinte forma:

$>$ Separação entre orações coordenadas, presentes nos documentos 03, linha 23 e documento 07 , linha 20 e 39 ;

Antecedendo conjunções conclusivas como ocorre no documento 07, linha 43;

Segundo Moraes, o hífen é:

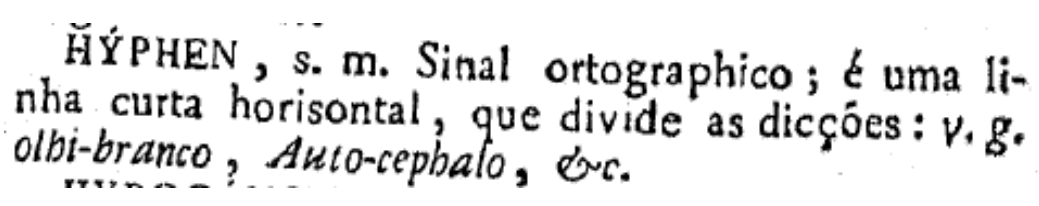

Figura 26 - Definição de Moraes para hífen

O hífen foi encontrado nos documentos 07,09 e 10 e sua finalidade foi a de separar elementos de palavras compostas ou ainda partes das mesmas palavras, devido à divisão de linha. Ainda que tais palavras mantenham sua independência fonética formam um conjunto e uma única palavra, o que mantém a unidade de sentido. Ribeiro (1881, p. 278) afirma que os hífens são sinais gráficos, responsáveis pela divisão das partes do discurso. O hífen, em específico, divide as palavras. Compreende-se, diante disso, que o sinal exerce a função de pontuação, pois se envolve na estrutura do texto. Estas ocorrências se deram nos seguintes documentos:

No documento 07, encontramos o emprego do hífen, separando o verbo do pronome, na linha $38, \mathrm{em}<$ aende $2>$.

No documento 09 , encontramos na linha $22,<$ boessar $-\infty e,>$, e no documento 10 encontramos o hífen como instrumento de separação pronominal<larar-erys. A 
segunda ocorrência encontrada no mesmo documento dá-se no vocábulo <

na linha 10, e $<$ poctender-ee $>$ e na linha 26.

A finalidade das aspas é abrir e fechar uma citação ou trecho inerente ao texto ao qual foi inserido. Ribeiro define a utilização das aspas afirmando que "são signaes que se põem no começo e no fim de uma citação, e muitas vezes mesmo no começo de todas as linhas della e no fim da última" (1881, p. 278)

Foram encontradas aspas nos documentos 03, linhas 31 e 37 e documento 06 , linha 13 . No primeiro documento a função das aspas é a inserção de dizeres dentro de um ofício e no segundo documento, a função é salientar o nome de um jornal.

Embora o ponto de interrogação e o ponto de exclamação já fossem utilizados na época, não foram encontrados nos documentos analisados. A seguir definição, apresentada por Ribeiro (1881, p. 276 e 277):

578. O ponto de interrogação põe-se no fim das sentenças interrogativas, ex.: Como passa? - Quantos são?

581. O ponto de admiração emprega-se no fim das phrases que exprimem affectos súbitos, considerações vivas e, em geral, depois das interjeições, ex: "Que prazer! Como é bello" - Ah!"

Tal ausência deve-se a fatores discursivos, uma vez, que o corpus trata de cartas da administração pública, cuja comunicação formal não solicitava a utilização de tais sinais.

Os dois pontos foram encontrados, somente, no documento 01, linha 16. Sua função foi enunciar uma explicação. Moraes (1806) iguala a função dos dois pontos ao do ponto e vírgula, ao afirmar:

O ponto e virgula (;) que aparta os sentidos perfeitos com dependência de outros: v. g. dice, que viria a manham, e que praticaria nisso; mas que em tanto etc. isto mesmo se nota talvez com dois pontos ( : ) Direi a Deis: Não me condemneis, Senhor." (p. 121)

Já Ribeiro (1881) subdivide as funções dos dois pontos e a função utilizada no referido documento encaixa-se no seu uso "antes de uma reflexão ou de uma explanação". (p.276)

Pelos empregos de cada sinal percebemos que todos são aplicados atualmente como o eram no século XIX. Não encontramos menção ao duplo hífen para separação de fronteira de palavra. 


\section{Sinais Diacríticos}

\subsection{Apontamentos e definições}

Em complementação a definição de Ribeiro (1881), citada no item 5.1, o autor esclarece que "os accentos são, pois, signaes lexeologicos" (p.274).

Os sinais diacríticos são apontamentos de acentuação. Nos documentos analisados
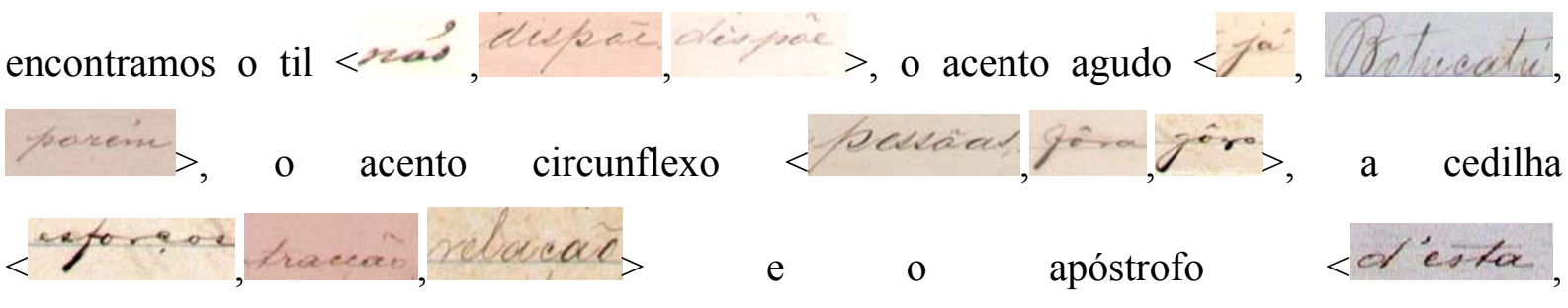

derecela. me cola $>$.

Remetendo ao significado da palavra "diacrítico", recorremos às mudanças prosódicas e fonológicas que boa parte desses sinais promovem, demarcando maior ou menor entonação na pronunciação das sílabas que os recebem.

Parte dos diacríticos levantados tem como função acentuar graficamente os vocábulos e, diante disso, e para delimitar a diferença entre o prosódico e o estrutural, recorremos ao vocábulo Accento para explicitar seu significado prosódico. Segundo a definição de Bluteau (1712):

ACCENTO. Geralmente fallando, he o tom da voz, ou a voz das fyllabas na pronunciação das palavras, porque por elle fè entende bem a fignificaçấo dellas. Tambem fe pode tonar pello ionico, cö que terimos, ou lcvantamos ma s huma 1yllaba, quando a pronunciamos, \& nos detemos mais nella, que em qualquer das outras de hum melino vocabulo, como quando dizemos Agùdo, Poêta, \&c. ferimosou, \& o e, \&os levantamos fobre todas as mais fyllabas.

Figura 27 - Definição de Acento em Bluteau 
Remetendo a prosódia encontraremos a seguinte definição em Bluteau (1712):

\section{Prosonia. He palavra Grega, que val o metmo que Acceuto, ou tom mais alto, ou mais bayxo da voz. E Profódia he a parte da Grammatica, que enfina; \& denota as fyllabas breves, \& longas. ?}

Figura 28 - Definição de Prosódia em Bluteau

Fernão de Oliveira (1536) na Grammatica da Lingoagem Portuguesa define o acento da seguinte forma:

Acẽto que dizer principal voz, ou tom dadição o ql acaba de dar sua forma e melodia as dições de qualquer língua/ digo as dições somẽte porque a linguajem ainda no ajuntamento das dições e no estilo e modo de proceder tem suas particularidades ou ppriedades: como a seu tẽpo em oura obra mayor q desta materea espero de fazer direi. (p. 57)

Ainda, no século XVI, Duarte Nunes do Leão em sua Orthographia da Lingoa Portvgvesa, reduzida a arte \& preceptos afirma que a variação de entonação da dicção de determinada letra, não fornece ao vocábulo sinal gráfico. Como exemplo citamos a letra $O$ :

Deuenos por tanto ficar por regra, que pois a differença consiste no accento, \& não na scriptura, que não teemos mais que hum $o \&$ que não se deue screver com $o$ dobrado, nenhũa dição, tirando da ultima sylaba, os nomes contractos, de que a diante faremos menção. Nem he necessário notar as palauras com accento, para fazer differença, quãdo he agudo, de quando he graue, ou circumflexo, por nao trazermos aa nossa lingoa o trabalho da lingoa Grega. (...) Soomente deuemos accentuar as dições, em que pode hauer differença de significação, quando teem differente accento, como: côr, por color, que screueremos com accento circumflexo, \& cór por vontade com agudo. E pôde, quando he preterito, screueremos com circumflexo, \& póde, do presente com agudo, \& assi outros desta qualidade. (1586, p. 17)

No século XVIII, Bernardo de Lima e Melo Bacellar, aborda em sua Grammatica Philosophica a entonação de cada sílaba associando-as ao tempo de pronúncia, dividindo-as em breves e longas, definindo o acento da seguinte forma:

Os Accentos dos Agentes, Nominativos \&c. he hum'a especie de canto (a); pois algumas as vezes constão aquelles de articulação, tempo, aspiração, e paixao (b). Ainda que só se trate da vogal breve `e da longa circunflexa ${ }^{\wedge}$, e da longuissima, ou aguda'; he esta a materia que affugenta os grammaticos, principalmente sobre as medias, por terem hum'as regras, cujas excepçoens, são muitas vezes quasi iguaes aos exemplos. (1783, p. 36 e 37 ) 
A Grammatica philosophica da lingua portugueza ou principios da grammatica geral applicados à nossa linguagem, de Jeronimo Soares Barboza faz menção à prosódia e à tonicidade das vogais, em capítulo denominado Regra dos Accentos

Tem Accento Agudo na ultima Syllaba todas as Palavras, que sejão Nomes, quer Verbos, quer Particulas, que acabarem, ou em algumas das nossas cinco vozes grandes á, é, ê, ó, ô, ou nas duas comuns i, u; ou em alguma das quatro Nasaes claras, ã, ĩ, õ, ũ, quer se escrevão assim, quer com m, deste modo am, im, om, um; ou em alguns dos Diphthongos Nasaes ái, áo, éi, éo, êo, ío, ói, ôi, úi, ou dos Nasaes ãi, ão, ẽe, õi, õo, ũi, quer se escrevão assim, quer de qualquer outro modo; e bem assim tem a ultima aguda todas as palavras, ou sejão nomes ou verbos, que acabarem no número singular por alguma das nossas tres líquidas $\mathrm{L}, \mathrm{R}, \mathrm{S}$, ou esta ultima se escreva assim, ou com Z, como o uso introduzio. (1862, p. 35)

Já no século XIX, Antonio de Moraes Silva, no ano de 1806 publica sua Epitome da Grammatica da Lingoa Portugueza $a^{4}$. Verifica-se que Moraes diferencia os acentos por sinais gráficos e diferentemente do latim, relaciona a entonação ao símbolo gráfico agudo ou grave, diferenciando a entonação e a escrita.

As lettras, com que representam os sons vogaes são Aa, Ee, Ii, Oo, Uu. Os sináes dos accentos, ou tons mais, ou menos fortes, com que proferimos as vogáes são (') agudo, ( ) grave: as mudas não tem sinal particular: o accento circumflexo não o temos; as vogáes, que com elle se notão, são graves. (b) As nasáes notamos com um til $(\sim)$, quando formão ditongos, v. g. mãe, são, veis, põis, cãiba, \&c. e quando são simples nasáes com ( $\sim)$ v.g. lã, sã; ou com m, v.g. cam-po, tem-po, sim-ples, pompa, Tum-ba; ou com o n, v.g. San-to, ben-to, sin-to, pon-to, jun-to. (1806, p. 12 e 13)

Embora, Moraes afirme que os diacríticos prosódicos são empregados somente em situações de diferenciação de significado, afirmação também presente em Soares Barboza, as definições apresentadas na Epitome, fazem menção aos quatro diacríticos - agudo, grave, nasal e o circunflexo -, como verificado na definição do $a$, ao relacionar significado semântico à entonação.

\footnotetext{
${ }^{4}$ A Epitome da grammatica da lingoa portuguesa passou a fazer parte do Diccionario da língua portugueza, como livro parte do primeiro tomo da obra, a partir de sua segunda edição, em 1813.
} 


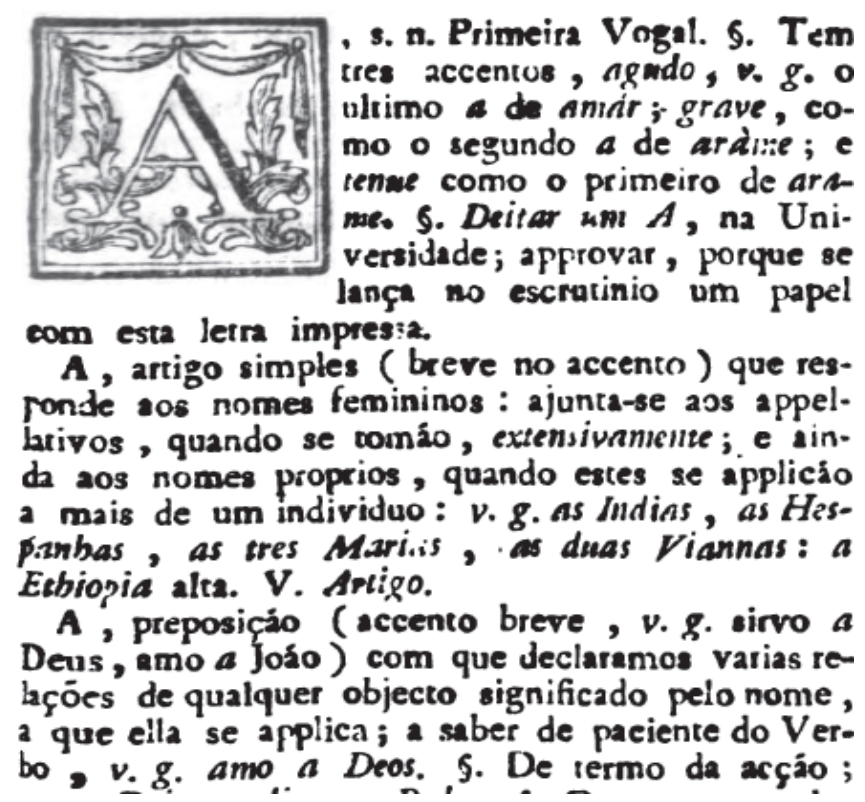

Figura 29 - Significado do A, em Moraes

Júlio Ribeiro em sua Grammatica Portugueza afirma que "os accentos são, pois, signaes lexeologicos" (p.274), e para a lexicologia há uma parte dedicada em seu livro. Na primeira parte denominada Lexeologia, aborda suas divisões: "phonologia e morphologia". Denomina Livro Primeiro a parte em que explicita as divisões da fonologia, e afirma que "as partes, pois, da phonologia são três: phonetica, prosódia e orthographia”. (RIBEIRO, 1881, p. 3)

A Seção Primeira aborda a fonética, definindo que "Phonetica é o tratado dos sons articulados, considerados em sua maxima simplicidade, como elementos constitutivos das palavras".

Na Segunda Seção define a prosódia:

Prosodia é o mesmo que accentuação: ambos os termos, etymologicamente considerados, referem-se á modulação dos sons, porquanto entre os Gregos e entre os Romanos a enunciação era uma como toada melodiosa. Nas línguas modernas prosodia tem a accepção restricta da definição. (p.10)

Complementa a definição informando que os acentos são "Notações orthographicas com que se compõem lettras para exprimir a natureza, a predominância, a contracção, a suppressão de vozes livres”. (RIBEIRO, 1881, p.24)

Diante das diferentes abordagens acerca do uso dos acentos e da relação estabelecida entre a pronunciação das sílabas e o uso dos sinais diacríticos percebeu-se que o uso dos diacríticos remontou à intensidade e entonação com que as sílabas eram pronunciadas. 
Tais características remetem ao emprego, que conhecemos hoje, de agudo, para a representação de vogais abertas, circunflexos, para a representação de sons fechados e til para representação da nasalidade.

Mas nem sempre foi assim. O agudo e o circunflexo eram utilizados para representar a intensidade da sílaba, mas não sua entonação. Atesta-se tal afirmação ao encontrar-se o agudo substituindo o til, na marcação de nasalidade, no século XIX. Foi encontrado no vocábulo creação < ereac,áó $>$, presente no documento 2, linha 8, p. 101, de 1868. Conforme Mattos e Silva (2006, p. 70) na primeira fase do português arcaico ocorria o uso do agudo para indicar a nasalidade. Era aposto sobre as vogais duplicadas os agudos para indicar a nasalidade, como em láá por lá e bóó por bom. Em verificação às gramáticas do século XIX não constatamos variação para o emprego da nasalidade como o uso do agudo, por exemplo, Diante disso, acreditamos que a ocorrência de agudo indicando a nasalidade pode referir-se a uma variante linguística do escriba, que o motivou a acentuar como pronunciava. Ao longo de nosso corpus serão verificadas ocorrências, em que a entonação da sílaba será o responsável pelo uso do acento.

Mas, trataremos dessas ocorrências no próximo capítulo, em que relacionaremos a prosódia aos fenômenos fonológicos e aos usos de sinais gráficos para determinação de marcação de intensidade.

\subsection{Acento agudo}

Recorrendo à história de nossa língua e às relações existentes entre prosódia e escrita buscou-se traçar uma relação entre os sistemas de tonicidade das vogais no latim clássico ao vulgar, ao português praticado no século XIX. Tal caminho tem como objetivo explicitar as mudanças fonológicas da língua para então adentrarmos no uso do diacrítico agudo como forma de marcação de tonicidade.

Com o objetivo de contextualizar o uso do acento agudo nos manuscritos do corpus foram consultadas gramáticas e dicionários de autores portugueses e brasileiros nos século XVIII, XIX e XX, para que se pudesse trilhar os aspectos fonético-fonológicos do período, bem como as questões ortográficas. Após os apontamentos do subcapítulo 6.1, em que verificamos os empregos do acento e de sinais gráficos, para diferenciar os significados de palavras iguais, percebemos que a aplicação dos diacríticos relaciona-se à pronunciação e 
intensidade com que são realizadas. $\mathrm{O}$ uso do sinal diacrítico não se figura em regras, mas sim em formas de diferenciar significados.

Exemplo disso é o vocábulo fórera <fórma>, presente no documento 06, linha 45, de 1881, p. 115 , cujo diacrítico marca a abertura da vogal e seu significado, que se diferencia de forma. Como define Moraes:

FORMA, s. f. Filosof. A disposiçáo da materia, que constitue uma especie distincta da outra, \$. Figura: v. g. tomou a tórma de um tigre: S. Modo: y. g. " desta fórma. "

Figura 30 - Significado de fórma

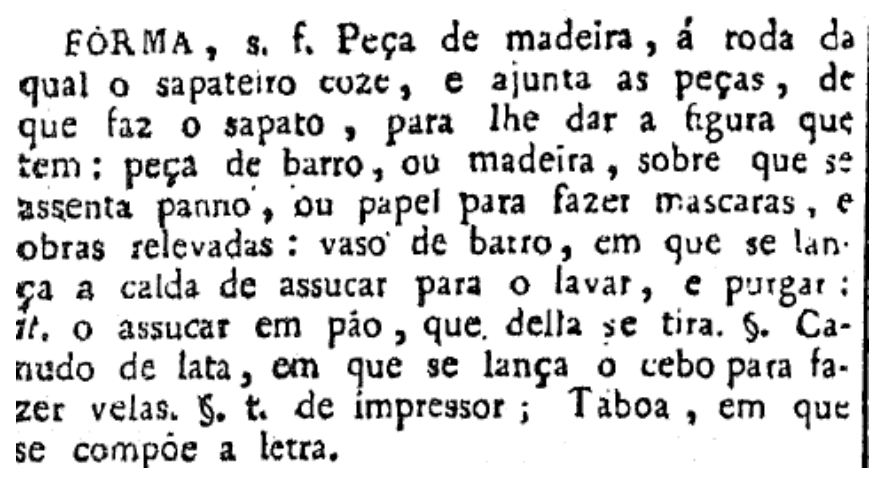

Figura 31 - Significado de forma

Apoiando-nos nesses contextos, buscou-se na pesquisa filológica indícios que nos permitam apontar para uma lógica ou regularidade do emprego dos diacríticos, semelhante ao que empregamos atualmente. Embora, regras específicas para seu emprego na época não tenham sido relatadas nas obras do século XIX consultadas, bem como nas gramáticas dos séculos XVI e XVIII.

Realizou-se uma contextualização histórico-gramatical das abordagens realizadas nas gramáticas e ortografias portuguesas. A partir das diferentes abordagens fornecidas pelos autores há possibilidade de levantar algumas hipóteses acerca dos critérios linguísticos para o uso dos diacríticos. Para tanto faremos uma análise diacrônica do processo de entonação e sistematização prosódica até o emprego destes acentos, que foram encontrados, no corpus analisado, sobre as vogais $a, e, o$ e $u$, pois foram estas que apresentaram a incidência dos diacríticos. 
Para tanto, partiu-se do latim clássico, para que as correlações entre a mudança de breves e longas para abertas e fechadas do latim vulgar também o fizemos para que fosse fácil a compreensão da empregabilidade dos diacríticos e da entonação utilizada nos dias atuais. Buscou-se em Faria (1957) na Fonética Histórica do Latim a relação entre a intensidade e altura das vogais latinas. A altura, no latim clássico, está relacionada à quantidade ou duração, denominação que será empregada no decorrer de todo o capítulo. Apoiado em Varrão, Faria menciona "Longitudo, termo da língua comum aplicável ao espaço ou ao tempo (comprimento, ou duração), refere-se aqui precisamente à duração silábica, razão por que reservamos-lhes o termo técnico quantidade”.(p.146)

Em relação à duração de pronuncia silábica, Nunes (1945) complementa:

Havia em toda a palavra latina, formada por duas ou mais sílabas, uma que era proferida com elevação de voz maior do que a restante ou restantes, na qual por consequência se feria uma nota mais alta ou aguda; era a tônica, em relação à qual as demais tinham o nome de átonas, e o acento era chamado de altura ou tom, para distinguir do de intensidade ou acento propriamente dito, que era um esforço maior empregado na emissão da sílaba inicial de cada palavra. (p. 32)

A variação da duração é a responsável pela designação de breves e longas. "Teoricamente pronunciam-se as breves em uma unidade de tempo e as longas em duas". (Faria, 1957, p. 65), ou seja, a duração com que as vogais eram pronunciadas faziam-nas breves ou longas, de acordo com as gradações da altura empregada.

As consoantes que acompanhavam as vogais também eram chamadas longas ou breves, mas possuíam regras específicas, como aponta Faria (1957):

Toda sílaba constituída por vogal breve, ou por vogal precedida de uma ou mais consoantes, é breve. Exs.: ă-lă-crĭ-tas, re-pli-cō, lŭ-pus, etc. Mas se a sílaba terminar por consoante seguida imediatamente de outra consoante, embora a vogal seja breve, a sílaba será longa. Exs: a-gěl-lus, ĭp-se, cǐs-to. Em todas estas palavras, ainda que o i de ĭpse e de cǐsta, e o e de agěllus sejam breves, as respectivas sílabas são longas, por virem estas vogais seguidas de duas consoantes. (p.136)

Toda sílaba constituída de vogal longa, por ditongo, acompanhados ou não de consoantes, é longa. Exs.: ha-bē-re, au-rum, pau-cum, ē-gī, etc. (p.137)

Quanto à intensidade da sílaba buscou-se relacionar o português do século XIX com o latim clássico, em Faria (1957), para que verificássemos diacronicamente tais ocorrências no corpus em questão. Sobre o acento de intensidade o autor relata:

Compreende-se por acento a ação de fazer ressaltar, em uma palavra, determinada sílaba denominada tônica, em relação às demais chamadas átonas. Isto pode ser conseguido de duas maneiras: 1) Pronunciando-se com mais força a sílaba acentuada, isto é, com mais intensidade, como acontece no português e nas demais 
línguas românicas; 2) Pronunciando-se a sílaba acentuada numa nota mais alta, isto é, com maior altura. No primeiro caso o acento será de natureza intensiva, no segundo será um acento essencialmente (ou preponderantemente) musical. (p. 134)

Este acento de intensidade deixou de existir no latim vulgar, devido às várias transformações da língua. A intensidade se uniria à duração e ambas seriam as responsáveis por apontar a sílaba mais forte, que também chamamos de sílaba tônica.

[...] pelo II ou III século, por motivo e razões que se ignoram aquele acento de altura se fundiu com o de intensidade e de essencialmente melodioso tornou-se quase que especial protector e defensor do som, isto é, continuou a ferir as mesmas sílabas de antes, mas agora com esforço especial, para não deixar perder o som vocálico. Desta época em diante desapareceu a distinção entre vogais breves e longas e a duração foi substituída pelo timbre; por outras palavras, a quantidade cedeu o lugar à qualidade. (NUNES, 1945, p. 40)

A intensidade no latim clássico era a força com que era empregada a primeira sílaba do vocábulo. No latim vulgar o acento de intensidade deu lugar às vogais abertas e fechadas. Willians (1973) menciona que:

o latim clássico sempre tivera um acento de intensidade e que um acento de altura, que jamais afetou a linguagem popular foi introduzido pelos meados do século II a. $\mathrm{C}$, entre as classes altamente bem educadas pelos professôres gregos que pronunciavam o latim à sua própria maneira. Cinco ou seis séculos mais tarde, o acento de intensidade da fala popular foi muito incrementado na boca dos gôdos invasores, que acentuavam o latim com o acento de intensidade mais forte característico de sua própria língua. (1973, p. 26)

O latim clássico era o latim presente na escrita e reservada às obras literárias, aos representantes da nobreza, diferenciando-os do latim utilizado pela plebe, chamado de latim vulgar. Mas é do latim vulgar que surgem as línguas românicas, dentre elas o português e será por tal motivo que nos ateremos na evolução deste idioma.

Muitos pontos apresentaram mudanças entre os dois tipos de latim. As vogais de dez reduziram-se a sete, os verbos passaram a apresentar um auxiliar, a duração deu lugar ao timbre e a intensidade fez com que as línguas românicas tomassem características próprias.

Para vislumbrar tais mudanças apresentamos a seguinte tabela, que menciona as mudanças entre as vogais latinas e as ocorrências de vocábulos: 
Tabela 20 - Mudança das vogais breves e longas às vogais abertas e fechadas

\begin{tabular}{|c|c|c|}
\hline Vogais do Latim Vulgar & Vogais do Latim Clássico & Exemplos \\
\hline$\overline{\mathrm{a}} \overline{\mathrm{a}}$ & $\bar{a}$ & $\begin{array}{l}\text { lătus > port. lado } \\
\text { amātum }>\text { port. amado }\end{array}$ \\
\hline$\check{\mathrm{e}}$ & $\varepsilon$ & $>$ port. terra \\
\hline $\begin{array}{l}\overline{\mathrm{e}}- \\
\overline{\mathrm{i}}\end{array}$ & e & $\begin{array}{ll}\text { rēte } & >\text { port. rede } \\
\text { sitium } & >\text { port. sede }\end{array}$ \\
\hline$\overline{1}$ & $\mathrm{i}$ & fĩcum $>$ port. figo \\
\hline$\breve{o}$ & 0 & pŏrta $>$ port. $p$ गrta \\
\hline$\overline{\mathrm{o}}-$ & o & amōrem> port. amor \\
\hline $\mathrm{u} \longrightarrow$ & & bŭcca > port. boca \\
\hline$\overline{\mathrm{u}}$ & $-\mathrm{u}$ & pūrum > port. puro \\
\hline
\end{tabular}

Adaptado de Maurer, T. Gramática do latim vulgar.

As dez vogais do latim clássico eram denominadas breves e longas. Essa classificação era possível devido à duração de cada vogal. No latim vulgar transformaram-se em abertas e fechadas, reduzindo-se a sete vogais, as vogais /a/ e /u/ não possuíam diferença de timbre.

Como mencionado por Moraes, no capítulo anterior, o uso de acentos para diferenciar o significado do vocábulo, também era utilizado no latim e o emprego de uma vogal breve ou longa alterava o seu significado. Cardera (2006, p.22) cita que:

a quantidade distinguia vogais latinas: a uma vogal longa correspondia uma maior duração; a uma vogal breve, uma menor duração. Assim, a palavra MĀLUM, com A longo, significava 'maça' enquanto MĂLUM, com vogal breve, significava 'mal'.

As transformações ocorridas no emprego de timbre (no latim clássico, duração) das vogais remetem, ainda, a mudança de grafia dos vocábulos, pois, as vogais breves do latim clássico transformaram em abertas e as longas em fechadas. A mudança ocorrida era de quantidade (longas e breves, atreladas à duração) para a qualidade (abertas e fechadas, atreladas a tonicidade).

Se considerarmos que a intensidade do latim vulgar fundiu-se com a duração, mantendo-se no latim vulgar o timbre das mesmas sílabas intensas do latim clássico, verificaremos que tal entonação perdurará no português moderno.

Tal sistematização de emprego das vogais deixou suas marcas na fala e escrita, dentre os quais abordaremos os sinais diacríticos. Nosso objetivo é contextualizar o emprego da intensidade e da altura (expressas nas vogais do latim clássico) ao timbre do latim vulgar. 
A reconstituição das intensidades, apoiando-se na verificação de sílabas breves e longas e sua influência na tonicidade nos mostrará a motivação para a acentuação das palavras.

Resgataremos por meio da etimologia do vocábulo a teorização para a aplicação de determinado acento, tentando estabelecer uma relação entre os acentos empregados graficamente com o funcionamento da prosódia latina.

No corpus analisado verificou-se que o acento agudo foi encontrado sobre as vogais $a$, $e, o$ e $u$, em substantivos monossilábicos e polissilábicos.

Embora nosso estudo seja fonológico subdividiremos os próximos capítulos em classes gramaticais por motivos didáticos.

\subsubsection{O Agudo nos verbos}

O agudo foi encontrado nos verbos dar, empregar, fazer, dever, poder, ser e ver. Os tempos verbais são o futuro do presente e o presente do indicativo, sempre na $3^{\mathrm{a}}$ pessoa do singular, pois o conteúdo dos ofícios era informativo e formal, o que contribuía para a aparição de verbos nestas pessoas.

Mattos (2006, p. 121) afirma que os verbos no latim clássico eram classificados em quatro conjugações, as quais terminavam em āre, ēre, ěre, ìre. Os verbos pertencentes a primeira conjugação tinham como terminação āre, os de segunda conjugação ēre, os de terceira ěre e em quarta conjugação os terminados em îre. No corpus em questão, os verbos pertencem a primeira, segunda e terceira conjugação.

$\mathrm{O}$ verbo fazer apresenta-se conjugado no presente do indicativo, na $3^{\mathrm{a}}$ pessoa do singular - fák $<$ fáz $>$. Tem sobre o grafema $<\mathrm{a}>$ o diacrítico agudo. Buscando a etimologia do vocábulo no latim encontramos facit. Originalmente, o verbo facěre pertence à terceira conjugação e, como grande parte dos verbos que pertencem a esta conjugação, sofreu mudanças entre a passagem do latim clássico para o latim vulgar, como aponta a tabela 10 . Sobre esta mudança Maurer (1959, p. 137) afirma que “(...) a exceção principal a (...) transferência dos verbos em io da $3^{a}$ para a $4^{\text {a }}$ conjugação é facěre, verbo muito usual, que continua na conjugação antiga, criando frequentemente uma $1^{a}$ pessoa *faco (e.g., esp. hago, rum. fac)". Isso ocorria porque os verbos terminados em ire passaram quase que totalmente para a quarta conjugação. 
Tabela 21 - Terminações dos verbos do latim da terceira e quarta conjugações ao português moderno

\begin{tabular}{|c|c|}
\hline $\begin{array}{l}\text { Latim clássico } \\
3^{\mathrm{a}} \text { conj./ } 4^{\mathrm{a}} \text { conj. }\end{array}$ & $\begin{array}{c}\text { Português Moderno } \\
\qquad 3^{\mathrm{a}} \text { conj. }\end{array}$ \\
\hline$-\mathrm{O}(-\breve{10}) /-\breve{10}$ & $-\mathrm{O} /-\mathrm{O}$ \\
\hline -is/ -îs & -es/ es \\
\hline -it/ - - it & $-e / e$ \\
\hline -ĭmus/ īmŭs & -emos/ imus \\
\hline 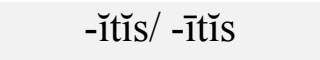 & -eis/ is \\
\hline -unt (-ı̌unt)/ - ıunt & -em/ em \\
\hline
\end{tabular}

No entanto, a analogia facěre $>$ fazer é uma exceção, pois no português moderno a terminação do verbo na terceira pessoa do singular não mantém a vogal /e/, embora, como afirma Coutinho (1976, p. 307) “a língua arcaica apresenta formas como fezi, fizi, fize, na $1^{\mathrm{a}}$

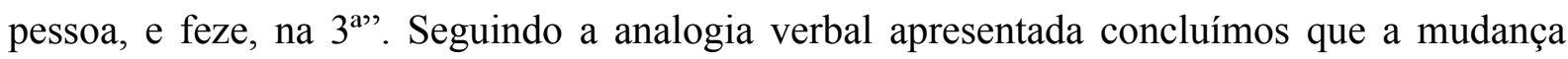
faz $<$ fazi $<$ facĭt foi possível com o emprego do $z$ em lugar do $c$ e queda da vogal final.

A motivação para o uso do acento agudo no verbo é o timbre com que se pronuncia a palavra, ainda, nos dias atuais. A forma verbal $<$ fáz $>$ segue o preceito da queda da última letra do verbo latino clássico, assimilando o restante da última sílaba $<c e r\rangle$, resultando na sonorização da consoante para a letra $z$. Para a $3^{\text {a }}$ pessoa do presente do indicativo ocorre o mesmo fenômeno: o/t/ é anulado e o /z/ sonoriza-se.

No latim clássico, a intensidade era a responsável pela entonação à sílaba inicial e facĭt reduziu-se a um monossílabo, o que sustenta a hipótese da intensidade empregada na sílaba inicial e a consequente utilização do diacrítico para marcar o timbre no português do XIX.

Willians (1973, p. 171) afirma que as formas verbais que em latim vulgar terminavam por $e$ átono precedido por $1, \mathrm{n}, \mathrm{r}, \mathrm{s}$ ou c perderam a última letra, influenciando as formas do Infinitivo, nas $1^{\mathrm{a}}$ e $3^{\mathrm{a}}$ pessoas do singular do futuro do subjuntivo, $3^{\mathrm{a}}$ pessoa do singular do presente do indicativo, $2^{\mathrm{a}}$ pessoa do singular do imperativo e a $1^{\mathrm{a}}$ e $3^{\mathrm{a}}$ pessoas do singular do presente do subjuntivo. Tais fenômenos foram motivações para a queda da vogal final. Neste caso, os respectivos verbos no infinitivo sofreram as seguintes mudanças: dēbēre $>$ deber $>$ dever e facěre $>$ fazer.

O verbo <deverá> dever á tem em sua etimologia o verbo dēbēre, apresenta-se na $3^{\mathrm{a}}$ pessoal do singular do futuro do presente. Todas as formas do futuro simples 
gramaticalizaram-se com o verbo auxiliar, o habēre, utilizado no tempo presente ou no imperfeito acompanhado do infinitivo do verbo principal. Diante disso, ter-se-ia dēbère habet (infinitivo de dever $+3^{\text {a }}$ pessoa do singular do presente do indicativo): dēbēre habet $<$ deber $h a t<$ dever há $<$ deverá.

Como define Mattos e Silva (2006, p. 119)

[..] a forma do presente pode expressar o futuro. Contudo perdidos os futuros perfectivo e imperfectivo do latim, formou-se, no romance, uma de locução verbal para a expressão da futuridade. Foi constituída do infinitivo de qualquer verbo seguido de habére, no indicativo presente ou no pretérito imperfeito (do tipo: amare + habeo/ amare + habebam), que por processos fonológicos regulares resultaram nas formas gramaticalizadas do futuro do presente/ futuro do pretérito (amarei/amaria)

No verbo exemplificado, o latim vulgar substituiu o futuro latino e criou um novo tempo: o condicional, que era constituído de um verbo no infinitivo acompanhado do presente ou imperfeito do verbo habere.

Em todos os casos constatamos a assimilação da vogal átona que compunha o ditongo ao fim do vocábulo, fazendo com que restasse apenas o $a$ tônico. Como ocorrido no verbo fazer há a perda da consoante final, no entanto, em < deverá> verificamos a duplicação da vogal $a$, que nos remete a ocorrências filológicas de duplicação de vogal para indicar a tonicidade da sílaba.

Mattos e Silva (2006) complementa, afirmando a causa da duplicação das vogais é a sincope de consoantes intervocálicas, do latim para o português, que "faz com que se represente na escrita do português arcaico sequências de vogais idênticas, ocupando ou não sílabas acentuada do tipo: máa, páaço, pée (...)”. (p. 64).

A intensidade da última sílaba do verbo $<$ rá $>$ deve-se a tonicidade empregada na conjugação do verbo habere na terceira pessoa do singular do presente do indicativo. A redução da forma do verbo hebere fez com que a intensidade recaísse sobre a última vogal, o que ocasionou, por conseqüência a tonicidade da ultima silaba do vocábulo.

Embora, não haja outros exemplos deste tipo de ocorrência no presente corpus, o futuro do indicativo formou-se a partir desta construção. Trata-se de uma forma de referenciar a vogal tônica. As vogais breves serão representadas em português como átonas e /a/, em sílaba final será a responsável pela tonicidade do vocábulo.

O verbo <empregará> tem como raiz latina o verbo implǐcāre. As vogais breves como o $\breve{1}$ e $\breve{\mathrm{u}}$ passam regularmente para $e$ e $o$. Diante disso o caminho etimológico do verbo é ı̌mplǐcāre<emplecare habet<emplegar hat< empregará. A 
substituição do /l/ pelo / $r /$ deve-se a dissimilação consonantal. Como ocorre no verbo $<$ dever $>$ a tonicidade da última sílaba deve-se a contração e assimilação do verbo habere. $\mathrm{O}$ /i/ presentes nas duas primeiras sílabas assimilou-se para /e/.

O verbo no infinitivo possuía como sílaba longa $\langle c \bar{a}>$ e tendo em vista, que no latim clássico "em palavras de três ou mais sílabas, a penúltima é acentuada se for longa, isto é, se contiver uma vogal longa" (WILLIANS, 1973, p.16), a sílaba em questão mantinha a intensidade. No latim vulgar a intensidade transformou-se em timbre e manteve-se no português do século XIX. Diante destas transformações o verbo empregar manteve a intensidade na sílaba $<$ gar $>$. O uso do acento gráfico não se dá no verbo infinitivo, mas ocorre quando empregado no futuro.

Além, da questão da intensidade aplicada a sílaba longa no latim vulgar ao timbre no vulgar o uso do diacrítico no tempo futuro, em detrimento, de sua utilização na sílaba intensa $<$ ga $>$ supomos que o empreso de sinal gráfico no tempo futuro ocorre para que haja diferenciação entre os tempos verbais.

O vocábulo latino apresenta como vogal longa o $\bar{a}$ e como sílaba longa o $c \bar{a}$, que permaneceu no português como sílaba tônica, no verbo no infinitivo.

Poderá < peres a > é um verbo conjugado na terceira pessoa do singular do futuro do presente do indicativo. Sua etimologia é pŏtēre $<p \supset$ dere $<$ poder. A sílaba longa no latim clássico é o $<t \bar{e}>$ e em português o $<$ der $>$. A queda da vogal final /e/ final foi verificada nos demais verbos analisados, devido sua posição postônica. A queda da vogal final ocorria, devido à possibilidade de formação de sílaba com os fonemas anteriores (COUTINHO, 1976, p. 106). A troca da consoante /t/ por/d/ deve-se a sonorização da consoante, como ocorreu em mutu $>$ mudo e fatu $>$ fado, por exemplo.

A forma verbal no latim vulgar previa a junção com o verbo habere, assim como ocorreu com o verbo empregar e dever. Diante disso, o verbo seria representado da seguinte maneira: pŏtēre habet>p $>$ dere hat>poder há>poderá.

Verifica-se que houve a apócope do $<\mathrm{t}>$ final do verbo hat e pressupomos que uma intensificação da sílaba final <rá> devido à assimilação. Isso também ocorreu com os demais verbos da terceira pessoa do singular no tempo futuro, cuja construção possuía a mesma estrutura.

O mesmo verbo, no presente do indicativo, $3^{\mathrm{a}}$ pessoa do singular foi encontrado no corpus. O acento agudo incide sobre a primeira sílaba - . Na língua atualmente falada isso ocorre e supomos que o acento agudo, empregado na sílaba $<$ po $>$, tentasse reproduzir sua 
abertura e tonicidade. Se seguirmos os indícios da etimologia da palavra chegamos a pŏtēt $>$ pode. O $o$ aberto mantém-se no português e a abertura da vogal é demonstrada pelo uso do acento agudo. A intensidade do latim clássico, que acentuava a penúltima sílaba mantevese no latim vulgar e deduzimos que essa manutenção de intensidade vocálica manteve o acento no português do século XIX.

Comprovamos tal afirmação ao encontrar em Barbosa (1862) e Moraes (1806) exemplificações do referido verbo acentuado com agudo na primeira sílaba. Logo, compreendemos que tal uso era usual na época.

O verbo fera < <erá> está na terceira pessoa do singular do futuro do indicativo. Irregular não manteve a mesma raiz e como aponta MATTOS e SILVA (2006, p. 132)

\begin{abstract}
Seer - se caracteriza por variações vocálicas e consonânticas nos seus dois lexemas heterônimos, já que, do latim para o português, confluíram no verbo seer os verbos latinos sedère e esse; reflexo disso nas formas do não-perfeito são a convivência no período arcaico das formas he ('é) e se, era e sua, sinônimos imperfeitos, já que as derivadas sedère (se, siia etc) ainda tinham o traço semântico de 'estar sentado' ou 'assentado', próprio a sedere
\end{abstract}

O infinitivo, no latim clássico, do verbo ser é sĕdēre, sendo conjugado nesta forma no português arcaico, mas não se manteve em sua totalidade, pois, muitas de suas formas foram substituídas por esse. "[...] Ser no início significou "estar sentado” [...]. Mas apareceu em data precoce com o sentido de "ser" [...]". (WILLIANS, 1973, p. 241). De acordo com Nunes

\begin{abstract}
o esse tomou de sedere, que tinha conjugação completa, formas que não possuía ou perdera no território galécio-português, como foram : o gerúndio, infinitivo e portanto o futuro e condiciona, o conjuntivo e imperativo. Ainda no presente do indicativo deram-se certas modificações: a primeira pessoa, depois de ter conservado durante bastante tempo a forma regula som, trocou pela atual sou, resultante da influência sobre aquela de igual pessoa de outro verbo, também de sentido idêntico, estar; a terceira perdeu regularmente o $t$ final e depois o $s$, que a tornava anômala e a confundia com a $2^{\text {a }}$; esta do plural foi refeita, ainda no latim vulgar, sobre a primeira do mesmo número [...]
\end{abstract}

Para a formação do tempo fututo seguiu-se a forma sedere o que resultou sĕdère habet $>$ seere há $>$ ser há< será. A assimilação da consoante medial $<\mathrm{d}>$ e da vogal $<\mathrm{e}>$ resultaram na transformação do verbo sĕdēre à forma como o conhecemos hoje. A assimilação das consoantes /d/ e /t/ marcam a mudança do verbo. Supomos que a assimilação da vogal /e/ que estava ao final da sílaba do verbo sedere habet possa ser a responsável pela tonicidade da última sílaba proveniente do verbo habet. 
Já no presente do indicativo verificou-se no corpus o $e^{<}<$é>, conjugação da $3^{\mathrm{a}}$ pessoa do singular do presente do indicativo, tem o seguinte percurso etimológico: est $>e s>e ́$. A vogal $<e>$ com som aberto, no latim vulgar, mantêm-se em português, sendo marcado com o diacrítico agudo.

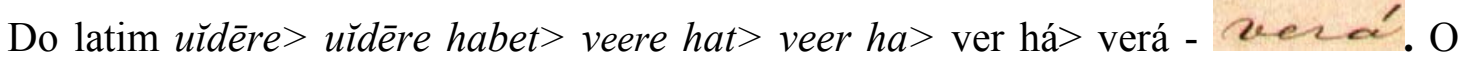
verbo pertence à $2^{\mathrm{a}}$ conjugação e foram conjugados na $3^{\mathrm{a}}$ pessoa do singular do futuro do presente, seguindo o mesmo padrão de evolução etimológica e fonológica dos demais verbos, pois o futuro em todos os casos foi composto pelo verbo auxiliar habere. Como ocorrido com o verbo ser a queda do /e/ final e do /d/ intervocálico.

Em econese, <acondúz>, oriundo do verbo conduzir, conjugado na terceira pessoa do singular do presente do indicativo traz consigo o pronome pessoal oblíquo antecedendo-o. Seguindo as regras da edição semidiplomática não foram separados os vocábulos, sendo mantidos como apresenta o documento originalmente. Proveniente do latim condūcěre $>$ conducer. O percurso etimológico do verbo conjugado é conducit $>$ conduce $>$ conduz. Assim como ocorre com facere o /c/ intervocálico seguido de /e/ ou /i/ sonoriza-se /z/, explicando a mudança linguística. A tonicidade da última sílaba $<d u z>$ manteve-se no português moderno, o que motivou o emprego do diacrítico agudo no verbo.

\footnotetext{
Tem Accento Agudo na ultima Syllaba [...] sejão nomes ou verbos, que acabarem no número singular por alguma das nossas tres líquidas L, R, S, ou esta ultima se escreva assim, ou com Z, como o uso introduzio. (1862, p. 35)
}

Neste caso, assim como em <fáz> não há a incidência de acento agudo no português de nossos dias, mas a existência de diacríticos nos manuscritos aponta para a tonicidade existente nas sílabas na época e persistentes ainda hoje.

A tonicidade aplicada a todos os verbos no futuro do presente deve-se a duplicação do grafema $<a>$ ao final da palavra, apontando para a tonicidade da última sílaba do verbo.

Quanto à tonicidade apontada pelo acento agudo no fim das palavras deve-se às transformações fonéticas ocorridas entre a passagem do latim vulgar para o português e a junção de dois verbos para a composição do futuro.

Diante disso, constatamos que a intensidade existente no latim clássico manteve-se como timbre no latim vulgar e no português e as mudanças recorrentes da língua proporcionaram o uso de acentos gráficos em parte das sílabas que sofriam maior intensidade. 


\subsubsection{Agudo nos artigos, preposições, pronomes e substantivos}

Exploraremos neste subcapítulo todos os substantivos próprios e simples, preposições, numerais e adjetivos. De forma menos análoga que ocorre nos verbos os substantivos trazem as mudanças ocorridas entre o latim clássico e o vulgar.

Selecionamos do corpus, somente, os vocábulos que apresentavam a incidência do agudo, de acordo com os vocábulos elencados nas tabelas 04, 05, 06 e 07, p. 47, 48, 49 e 50.

Analisado de forma independente o lexema $\stackrel{-}{-},<a ́>$, segue o padrão de duplicação de fonemas e posterior acentuação. O referido fonema exerce a função lexical de preposição e artigo. Em latim vulgar seria representado por a duplo $<$ aa $>$, como ocorria em cree de crēdit, por exemplo. Posteriormente receberia o acento agudo e a eliminação de um dos grafemas. Lembremo-nos que o $a$ tônico português também possuía intensidade no latim.

No capítulo 6.1, através da figura 29 vemos que Moraes faz referência a preposição $a$, como receptor de accento breve, ou seja, sem acento gráfico. Para identificarmos a função do lexema dentro do contexto frasal apresentamos as expressões completas:

Relacionamos a preposição com a palavra posterior, para que fosse possível traçar as perspectivas para o emprego do acento, como ocorreu em ${ }^{\alpha}$ mangem $<$ á margem>,

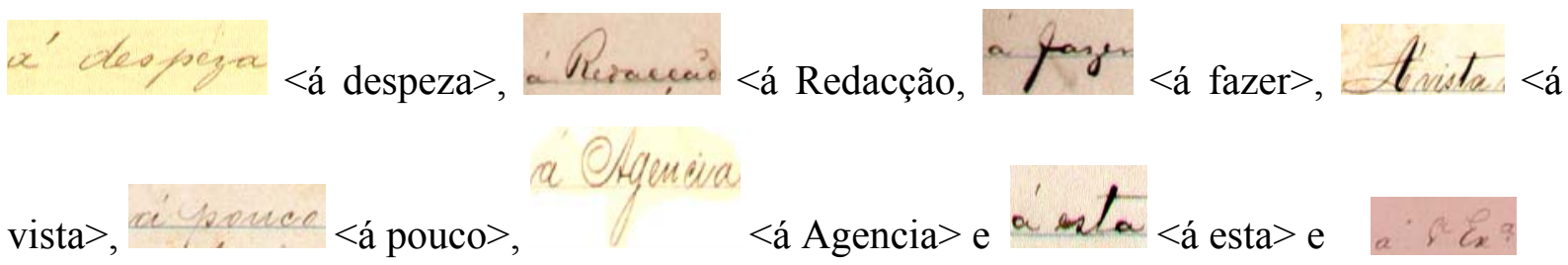
$<$ á $\mathrm{V} . \mathrm{Ex}^{\mathrm{a}}>$.

$\mathrm{O}$ à é uma junção entre artigo /a/ e a preposição /a/, logo, uma contração, que atualmente é grafada com crase. O artigo $a$ em latim vulgar era /illa $<$ la/ e a preposição $<\mathrm{a}>$. Willians (1973, p. 38) atribui o uso das vogais duplas à queda de uma consoante intervocálica, que explicaria a ocorrência, mencionando ainda:

No início do século XVI vieram a ser usadas para indicar o som aberto de vogal (a, e, o), sendo o fechado indicado por uma vogal simples. Êsse uso é mencionado por Fernão de Oliveira, em 1536, na sua Gramática da Lingoagem Portuguesa.

A função do à na maioria dos casos assemelha-se a crase, que utilizamos atualmente. No século XIX a crase (') não era usual e como afirma Ribeiro (1881, p. 24) "Alguns lexicographos usam do accento grave ('), para marcar os sons fechados: tal accento, extranho 
ao portuguez, acha-se banido do uso geral." E complementando a afirmativa o mesmo autor fornece a regra para uso do acento agudo sobre a letra $a$ : "O accento agudo colloca-se 1) sobre $a$ inicial para indicar contracção de vozes similhantes, ex: "á” por "aa”, “áquelle” por "a aquelle”. “(1881, p. 24).

As relações de intensidade aplicadas à pronúncia explicam a utilização do acento e também nos fornecem argumentos para explicar o uso do agudo em casos como <á esta $>,<$ á Margem $>,<$ á despeza $>,<$ á redacção $>,<$ á vista $>$, $<$ á agencia $>$. Excetua-se a essa definição o $a ́$ diante do verbo fazer. Supomos que o uso de tal acento diante de verbo deve-se ao conhecimento da língua francesa. Embora, o acento empregado no francês seja o grave ("), o escriba não o utilizou devido ao seu não emprego na escrita portuguesa do século XIX, pois como afirma Ribeiro.

No vocábulo < dáquella $>$,

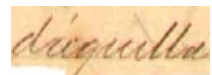

encontramos o acento agudo em substituição ao apóstrofo. O emprego desse diacrítico em lugar do agudo foi realizado pelo escriba do documento 07, ano de 1889. Analisando todo o documento 07 verificamos outras ocorrências, em que o agudo foi utilizado em substituição ao apóstrofo, como em < désta>,

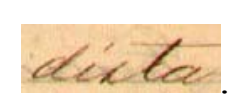

A função do apóstrofo é a supressão de uma vogal que se repetia. No exemplo d'aquella>de aquella, seguindo o padrão de assimilação da vogal /a/, o escriba empregou o acento agudo sobre a vogal ainda que não existisse a supressão das vogais $a$ para tal uso.

Outra hipótese é o emprego do acento por causa do timbre da sílaba e o desuso dos apóstrofos. Ribeiro, em sua Grammatica Portugueza (1881, p. 25) afirma:

\footnotetext{
O uso do apostropho vai-se tornando cada vez mais raro na prosa. Escrevese hoje delle, do, lho, etc e não mais d'elle, d'o, lh'o". A dife renciação necessária entre certos vocábulos faz-se por meio do accento agudo: assim désse, deste, fórmas do verbo dar, levam que as distiga de desse, deste, contracções de de esse, de este.
}

O vocábulo < désta $>$ é um pronome demonstrativo. Apesar do desuso do apóstrofo e da necessidade de seu emprego para diferenciar verbos e pronomes o escriba fez uso do agudo para demarcar a entonação da sílaba. Compreendemos que esse foi o motivo, pois emprega no vocábulo $<$ ¿́cta $>$ o agudo para marcar a primeira sílaba. 
Ambas as forma provém do latim ĭsta $>$ عsta (WILLIANS, 1973, p.159). A abertura da primeira vogal remete a entonação empregada em ambos os vocábulos, explicando o uso do acento agudo.

O substantivo próprio fahué , <Jahú> aponta-nos a intensificação da tonicidade na última sílaba ao acentuá-la, mantendo o $<\mathrm{h}>$, que tem como finalidade "marcar o hiato entre duas vogais diferentes ou entre vogais de qualidade diferente" (WILLIANS, 1973, pp. 35) \% $^{5}$ O vocábulo de origem tupi provém de ia'u, mas seu uso entre os portugueses forneceu-lhe várias formas de escrita: jaú, jaû, jau e jahú. (Cunha, 1999, p. 176)

Compreendemos que a utilização do $/ \mathrm{h} /$ relaciona-se com a marcação de intensificação de tonicidade da última sílaba e que o vocábulo é de origem tupi, no entanto, sofreu alterações e influências do português do XIX. A tonicidade da última sílaba era própria do tupi e a marcação da intensidade foi aplicada com o uso do /h/ e do acento agudo sobre a tônica.

Outro nome próprio é Shé, <Itú> que diferentemente de Jahú não configura hiato, mas utiliza o acento agudo para registrar a tonicidade do vocábulo. Sua origem etimológica é i-‘tu do tupi, que significa cachoeira. (Houaiss, 2008, p. 1661) A tonicidade da última sílaba foi mantida com o emprego do acento agudo.

Outro exemplo de substantivo próprio acentuado em sua última sílaba é Do tucal $<$ Botucatú>, cujo caso é semelhante à ocorrência $<$ Itú $>$. Do tupi ïbi'tuka'tu significa "vento bom". (Houaiss, 2008, p. 499) O nome do município paulista recebeu o acento na última sílaba devido à influência etimológica da palavra.

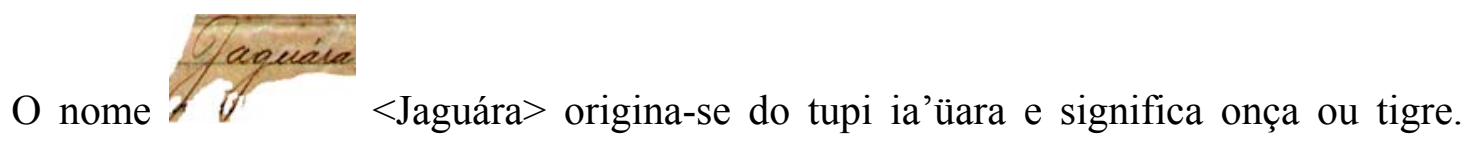
(Cunha, 1999, p. 170). Como os demais vocábulos a intensidade aplicada na língua tupi manteve-se no português. Para apontar a tonicidade da sílaba medial o escriba fez uso do acento agudo.

\subsubsection{Agudo nos advérbios}

\footnotetext{
${ }^{5}$ O Prof. Dr. Ivo Catro (Universidade de Lisboa), em comunicação pessoal, chamou esse processo de travamento de vogal na escrita.
} 
Ainda relacionando os vocábulos que apresentaram diacríticos sobre a letra $<a>$ partiremos para o advérbio,$<$ já $>$. Seu caminho etimológico é o seguinte: Jam $<$ yaa $<$ $y a<$ já. Percebe-se que a nasal foi substituída pela duplicação do $/ a /$ o que nos oferece uma pista sobre a ocorrência de sinais agudos marcando a nasalidade em alguns vocábulos. No entanto, o advérbio em questão possuía uma nasal ao final e para que se intensificasse o grafema $<a>$ o mesmo passou a ser grafado duplicadamente, pois “ A duplicação das vogais tinha como objetivo demonstrar a tonicidade da vogal. (NUNES, 1945, pp. 66)”.

Mattos e Silva (2006) complementa, afirmando a causa da duplicação das vogais é a sincope de consoantes intervocálicas, do latim para o português, que "faz com que se represente na escrita do português arcaico sequências de vogais idênticas, ocupando ou não sílabas acentuada do tipo: máa, páaço, pée (...)”. (p. 64).

$\mathrm{O}$ advérbio e ó <só> etimologicamente o advérbio provém de sōlum. Fenômenos linguísticos A tonicidade existente atualmente e no português do século XIX deve-se a queda da consoante medial /1/ e assimilação da sílaba final. O acento tônico, no latim clássico, recaia sobre a primeira sílaba e assim se manteve no latim vulgar. Isso favoreceu a manutenção da primeira sílaba e assimilação do restante da palavra.

\subsection{Til}

Serão verificadas somente as condições para utilização do sinal diacrítico em questão, não se aprofundando nas questões referentes ao fenômeno de nasalização, mas sim a utilização do referido diacrítico com base nas teorias gramaticais da época e em estudos acerca do assunto.

O til, conforme definição de Bluteau (1712) é:

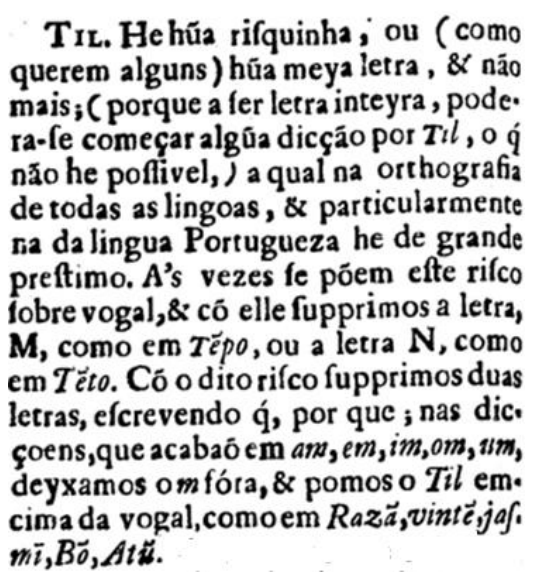

Figura 32 - Definição de Til em Bluteau 
Nos manuscritos analisados não foram encontradas ocorrência em que o til efetivamente substituísse as letras, mas complementando-as apondo-se sobre as letras $a$ e $o$ para marcação de plural. Seguindo Nobiling (1976, p.87), tais ditongações pertencem ao grupo de vogais fortemente nasalisadas e que sofreram a absorção das consoantes nasais $m$ e $n$ latinas. Comprovamos tais afirmações confrontando a etimologia dos referido vocábulos ao resultado final de cada um.

Tabela 22 - Vocábulos e etimologia

\begin{tabular}{|c|c|c|c|}
\hline Ordem & Vocábulos & Localização & Mudanças lingüísticas \\
\hline 01 & & $\begin{array}{l}\text { linha } 35 \text {, doc. } \\
03\end{array}$ & Ponere $>$ disponere $>$ Dispoe \\
\hline 02 & yacs & $\begin{array}{l}\text { linha } 34 \text {, doc. } \\
06\end{array}$ & Declarationis $>$ declaratio $>$ declarações \\
\hline 03 & <ondadar & $\begin{array}{l}\text { linha } 06 \text {, doc. } \\
10\end{array}$ & $\begin{array}{l}\text { çibdadao>cidadã }>\text { cidadão (Cunha, 1982, } \\
\text { p. 182) }\end{array}$ \\
\hline
\end{tabular}

As ocorrências deram-se em 100\% dos casos em final de palavra ou ainda em palavras monossilábicas. Concluímos, diante disso, que a nasalidade dos vocábulos deve-se a queda de $n$ intervocálico. Nas linhas 01 e 03 da tabela acima atestamos que a localização do diacrítico sobre a segunda vogal, também reforça a existência de um $n$ intervocálico.

Observamos que grande parte dos vocábulos possuem o til sobre os grafemas $<\mathrm{a}>$ ou $<_{0}>$, havendo ocorrências de acentuação sobre o $<\mathrm{e}>$. Encontramos nos documentos incidência do acento sobre o $n$, como indicação de nasalidade. Esses usos foram aplicados, somente, em casos de abreviatura da palavra senhor. Tais ocorrências estão relacionadas nas tabelas $8,9,10$ e 11 , nas páginas 52,53 e 55 .

\subsection{Acento circunflexo}

Assim como o agudo o acento circunflexo foi encontrado nos ofícios para marcação de intensidade. Não se configura, como regra, a pré-determinação de que tipo de som explicita, sendo aplicado ora para designar o aberto e ora o fechado.

Na definição de Moraes sobre o circunflexo já existe divergência sobre seu uso. Nas gramáticas analisadas somente menciona o uso do acento circunflexo para apontar o “fechamento da voz". Moraes (1806) afirma: 
O acento circumflexo dos Antigos era sinal de levantar o tom da vogal, e logo abaixá-lo; nós não temos semelhantes vogáes, e o accento cricumflexo nos é desnecessário; os nossos Grammaticos accentuão com elle vogáes graves: v. g. vêo, fèo, por vèyo, fèyo, etc. Commumente não usamos de accentos prosódicos, se não é para distinguir palavras homônimas, ou da mesma escritura, e diversos sons e sentidos: v. g. ésta a casa de Pedro; está a casa de Pedro; azèdas adject. de azédas verbo [...]. (Moraes, 1806, p. 120)

Em seu Diccionario da Língua Portugueza, define:

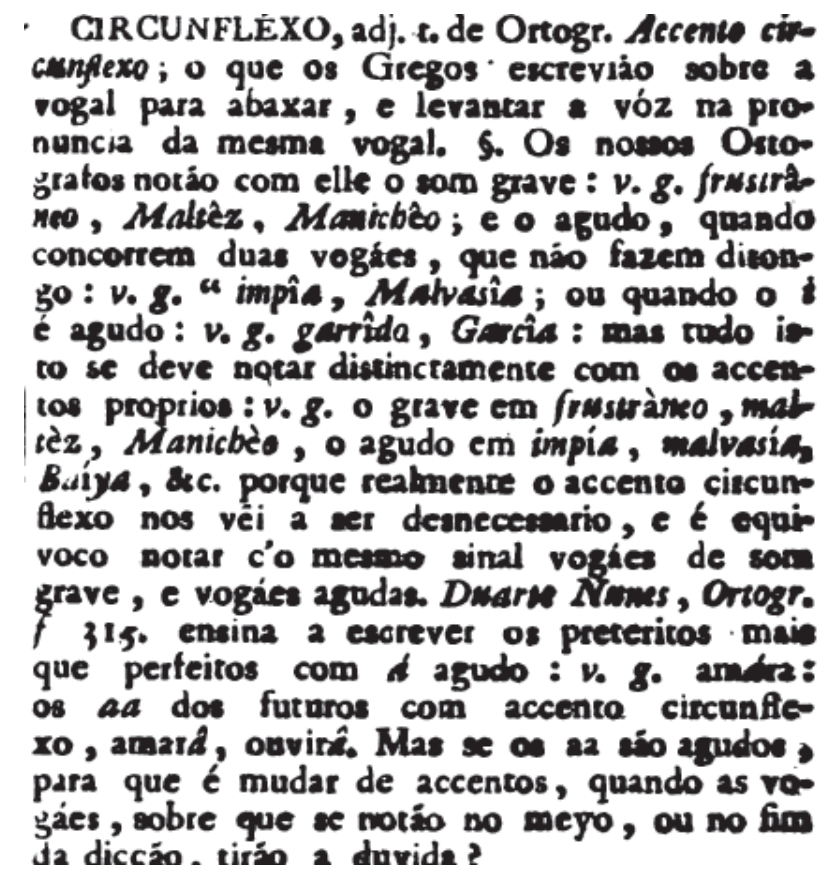

Figura 33 - Definição de Circunflexo em Moraes

$\mathrm{O}$ acento circunflexo foi encontrado sobre as vogais $\langle\mathrm{e}>\mathrm{e}<\mathrm{o}>$, ocorrendo somente nos documentos 03, 08 e 09. Não foram encontradas ocorrências de circunflexo sobre /a/. Para consulta há as tabelas 15 e 16, páginas 57 e 58 .

No documento 03 , linha 27, o vocábulo parãad, <pessôas>, vem do latim pĕrsōna. Se considerarmos que a vogal longa $\bar{o}$ transforma-se, no latim vulgar, em vogal fechada, logo com timbre fechado, o diacrítico circunflexo sobre a letra reproduz a tonicidade da vogal realizada no latim vulgar. Dessa forma, a aplicação do circunflexo, nos dias atuais, para marcação de fechamento da vogal ocorreria.

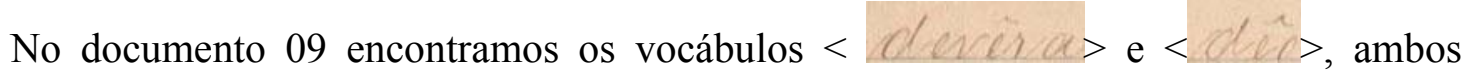
verbos presentes na linha 37 . O primeiro é o verbo dever na $3^{a}$ pessoa do singular do pretérito mais-que-perfeito e sua origem latina é debuĕrat. A consoante final / $t$ / caiu no latim vulgar e a consoante /b/ deu lugar ao /v/ acompanhado da queda da vogal / $/$ / resultando em $<$ devêra $>$. A 
tonicidade apresentada pela vogal breve /e/ manteve-se em português e foi expressa por meio do diacrítico circunflexo sobre a mesma vogal. No entanto, a tonicidade não demonstra uma vogal aberta, mas sim com som fechado ao contrário que sua versão em latim vulgar apresentaria.

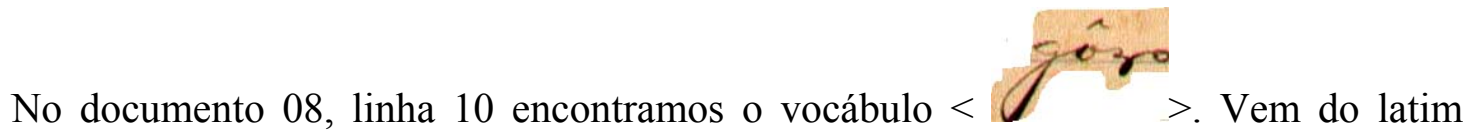
gaudĭum. No latim vulgar o ditongo au reduziu-se à letra $o$, resultando em godĭum e com a assimilação do /d/ tranformou-se em gôzo. Nunes afirma que o referido vocábulo advem do castelhano goço.

Em verificação ao Vocabulário de Bluteau (1712) encontramos a definição de gozo e o vocábulo esta grafado com grave sobre a primeira sílaba. Acreditamos que tal uso seja um indício de fechamento silábico, uma vez que o uso do circunflexo não era comum no início do século XIX e fins do XVIII. Esse diacrítico não era difundido para determinar a marcação de timbres vocálicos, o que fazia com que não fosse empregado como o agudo.

\subsection{Cedilha}

A cedilha foi encontrada sempre sob a letra /c/, antes de /a/ e /o/. Houve uma ocorrência de cedilha antes de /e/, mas o vocábulo é um nome próprio. Para ilustrarmos apontamos as ocorrências de cada manuscrito, nas tabelas 17, 18 e 19, páginas 58 e 60. Como afirma Moraes (1813):

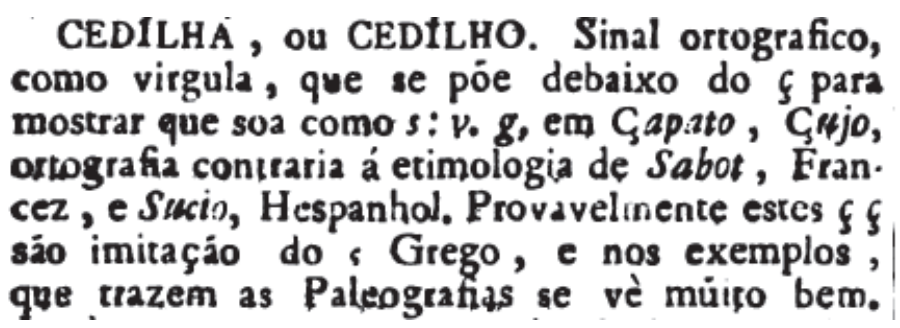

Figura 34 - Definição de Cedilha em Moraes

Ribeiro (1881, p. 23) ao classificar as consoantes faz a seguinte relação: “cc, ç, cç, pc, ps, sc, ss= c em face", ou seja, tal relação de letras compostas, incluindo o $c$ equivalente a $c$. Afirma, ainda, que o emprego do $c ̧$ deve ser realizado diante, somente, a, o e u. Tal emprego dá-se sempre em meio de vocábulo. Em início de palavra a cedilha, utilizada na escrita de çapato, por exemplo, deveria ser substituída por $s$. 
Nos vocábulos da tabela 22, p. 89, verificamos a mudança etimológica de alguns vocábulos que possuíam a cedilha em sua composição e percebemos que vocábulos com - $t i$ transformaram-se em $c ̧$, como declaratione, por exemplo.

Nunes (1945, p. 144) afirma que a mudança do $t i$ para $c ̧$ ou $z$, como ocorre em ratione>razão é muito antiga e os vocábulos com - $t i$ e $-c i$ evoluíram para $z$, tendo em vista que palavras dessa fase do latim possuíam tratamento mais regular. A mesma duplicidade de representação se dá nos vocábulos espanhóis.

Cuervo (1948, p. 206) afirma que a cedilha:

Encuentráse en voces árabes como rezma, mezquita y mezquino. Aquí debe haber obrado la tendência a pronunciar como vocálica la silbante al fin de sílabas como al fin de palabra, tal que la ç se convertia em z em esta posición: descoraznar de coraçon $[\ldots]$

Na tabela 22, o vocábulo Cidadãos traz sua origem etimológica e a sílaba inicial era grafada com ç e transformou-se em c. O emprego do $c ̧$ em início de palavra deu-se até início do século XIX, conforme Ribeiro (1881, p. 40) e foi substituído das posições iniciais, dando lugar ao uso do $c$, antes de $e$ e de $i$ e do $s$, antes de $a$, $o$ e $u$.

Essa mudança explica-nos a não incidência de vocábulos iniciados por ç, ou ainda, com çe. A única ocorrência foi o sobrenome Fonçeca, possivelmente, grafado no período arcaico da língua.

\subsection{Apóstrofo}

Os apóstrofos também foram encontrados nos documentos analisados. O objetivo deste tipo de sinal gráfico é a aglutinação das palavras. Bluteau (1712) define o diacrítico como:

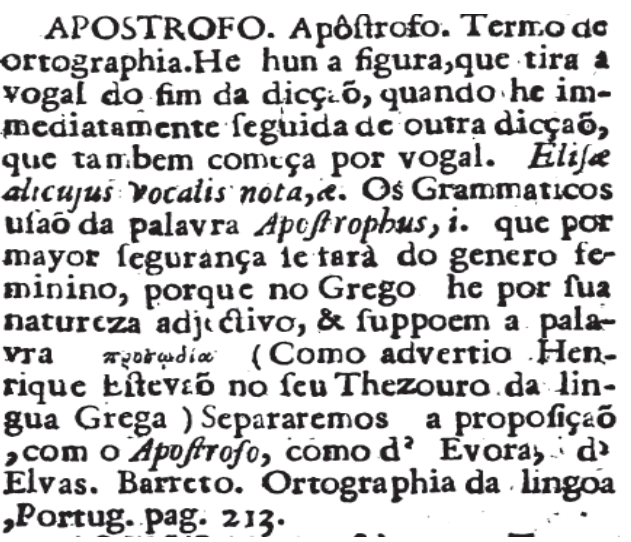

Figura 35: Definição de Apostrofo em Bluteau 
No documento 02 o sinal foi encontrado no vocábulo $\langle$ n'esta $\rangle$, na linha 8 . É resultado da aglutinação da preposição - em e o pronome -esta.

No documento 03 ocorreu em $<$ dínecela $>$, linhas 19 e 36, como forma de contração entre a preposição -de e o pronome -aquella.

O documento 04 apresenta as contrações nos vocábulos $\left\langle d^{\prime} e_{\text {- }}\right.$ la $\rangle$, linhas 05,28 , 30 e 52 e < $/$ ester, linhas 41 e 43.

No documento 10, o vocábulo $<\delta$ E te $>$, linha 30, apresenta este sinal gráfico, que neste caso aglutinou da preposição $<$ de $>$ e o pronome $<$ este $>$.

Nas tabelas 12, 13 e 14, páginas 55, 56 e 57 os vocábulos estão divididos por documentos.

O apóstrofo tinha como função a contração de vogal repetida na junção de uma preposição com um substantivo, como ocorreu em em + esta-nesta , de+esta - nesta.

Barbosa (1862, p. 72) define o apóstrofo como:

Virgula, não já posta em baixo para signal de pausa, mas no alto de uma consoante par amostrar que lhe supprimio a sua vogal final antes de outra inicial da palavra seguinte, com a qual vogal se ajunta a mesma consoante, pronunciando-se juntas as duas palavras, com Minh'alma.

Ribeiro (1881) também menciona a redução do uso do apóstrofo e comprovamos essa afirmação verificando as tabelas acima mencionadas. A ocorrência do apóstrofo deu-se somente em quatro documentos dos dez analisados, com maior incidência na elisão da vogal $e$ em detrimento das demais. 


\section{Terceira Parte}

\section{Edição semidiplomática dos documentos da Administração dos Correios}

\subsection{Normas para a transcrição dos documentos}

A presente transcrição seguirá o critério apresentado no Segundo Seminário para a História do Português do Brasil realizado, em Campos do Jordão, no período de 10 a 16 de maio de 1998, elaborado pela Comissão de elaboração de normas para transcrição de documentos manuscritos para a História do Português do Brasil. A mesma foi base para a edição dos manuscritos de Por Minha Letra e Sinal, organizada por Heitor Megale e Silvio de Almeida Toledo. Adaptações das normas foram realizadas para que a presente transcrição se adequasse a lição, a saber:

1. A transcrição será conservadora;

2. As abreviaturas, alfabéticas ou não, serão desenvolvidas, marcando-se, em itálico, as letras omitidas na abreviatura, obedecendo ao seguinte critério:

respeitará, sempre que possível, a grafia do manuscrito, como no caso da ocorrência "excellentissimo", que leva a abreviatura "exmo"

$>$ no caso de variação, a opção será para a forma atual, seguindo o apresentado pelo manuscrito. Como exemplo, citamos a abreviatura Sñr, que será transcrito Senhor.

3. Não será estabelecida fronteira de palavras que venham escritas juntas, nem se introduzirá hífen ou apóstrofo onde não houver. Exemplos: emesmo; setem; deSão; omais; acondúz;

4. A pontuação original será mantida. No caso de espaço maior intervalar deixado pelo escriba, será marcado: [espaço]. Exemplo: por estafeta até São Manoel. [espaço] Nesta data e para este fim;

5. A acentuação original será mantida, não se permitindo qualquer alteração. Exemplos: Botucatú; creaçáo; dáquella;

6. Em ocorrências em que o diacrítico localizar-se entre vogais, será considerada a acentuação utilizada no restante do documento. Caso não haja parâmetros, o diacrítico será posto sobre a primeira vogal. Exemplo: condicçaõ; naõ; condicçoẽs; São; administração;

7. Será respeitado o emprego de maiúsculas e minúsculas como se apresentam no original. No caso de alguma variação física dos sinais gráficos resultantes de fatores cursivos, não será 
considerada relevante. Assim, a comparação do traçado da mesma letra deve propiciar a melhor solução.

8. Inserções de copista ou do escriba na entrelinha ou nas margens superior, laterais ou inferior entram na edição entre os sinais $<>$, na localização indicada.

9. Supressões feitas pelo escriba ou elo copista no original serão tachadas. No caso de repetição que o escriba ou o copista não suprimiu, passa a ser suprimida pelo editor que a coloca entre colchetes duplos.

10. Intervenções de terceiros no documento original, devem aparecer no final do documento informando-se a localização. Caso haja mais de uma linha a mudança de linhas será representada por uma vertical. Ex: margem lateral esquerda situam-se os dizeres ao Engenheiro Fiscal para informar, |entendendo-se com o Superintendente |Postal do Governo de São Paulo. |15 de julho de 1879. |Abelardo de Brito

11. Intervenções do editor serão raríssimas, permitindo-se apenas em caso de extrema necessidade, desde que elucidativas a ponto de não deixarem margem à dúvida. Quando ocorrerem devem vir entre colchetes;

12. Letra ou palavra não legível por deterioração justificam intervenção do editor na forma do item anterior, com a indicação entre colchetes [ilegível];

13. Trecho de maior extensão não legível por deterioração receberá a indicação [corroídas + ou - 5 linhas]. Se for o caso de trecho riscado ou inteiramente anulado por borrão ou papel colado em cima, será registrada a informação pertinente entre colchetes e sublinhada

14. A divisão das linhas dos documentos original será preservada e não receberá indicação, sendo justalinear. A mudança de fólio receberá a marcação com o respectivo número na seqüência de duas barras verticais: ||1r.|| ||1v.|| ||2r\|| ||2v\|;

15. Na edição, as linhas serão numeradas de cinco em cinco a partir da quinta. Essa numeração será encontrada à margem direita da mancha, à esquerda do leitor. Será feita de maneira continua por documento;

16. As assinaturas simples ou as rubricas do punho de quem assinam serão sublinhadas. Exemplos: assinatura simples: Jose Luiz Ney da Silva; sinal público:[Jose Alues da Fonseca] ;

17. Marcas oficiais, como timbres, logotipos e carimbos serão mencionados como nota de rodapé. 
Edição semidiplomática dos documentos da Administração Geral dos Correios 
Documento 01: enviado pela Administração do Correio da Vila de Lorena o Administrador de São Paulo, em 28 de novembro de 1833. Justificativa referente aos atrasos de entrega.

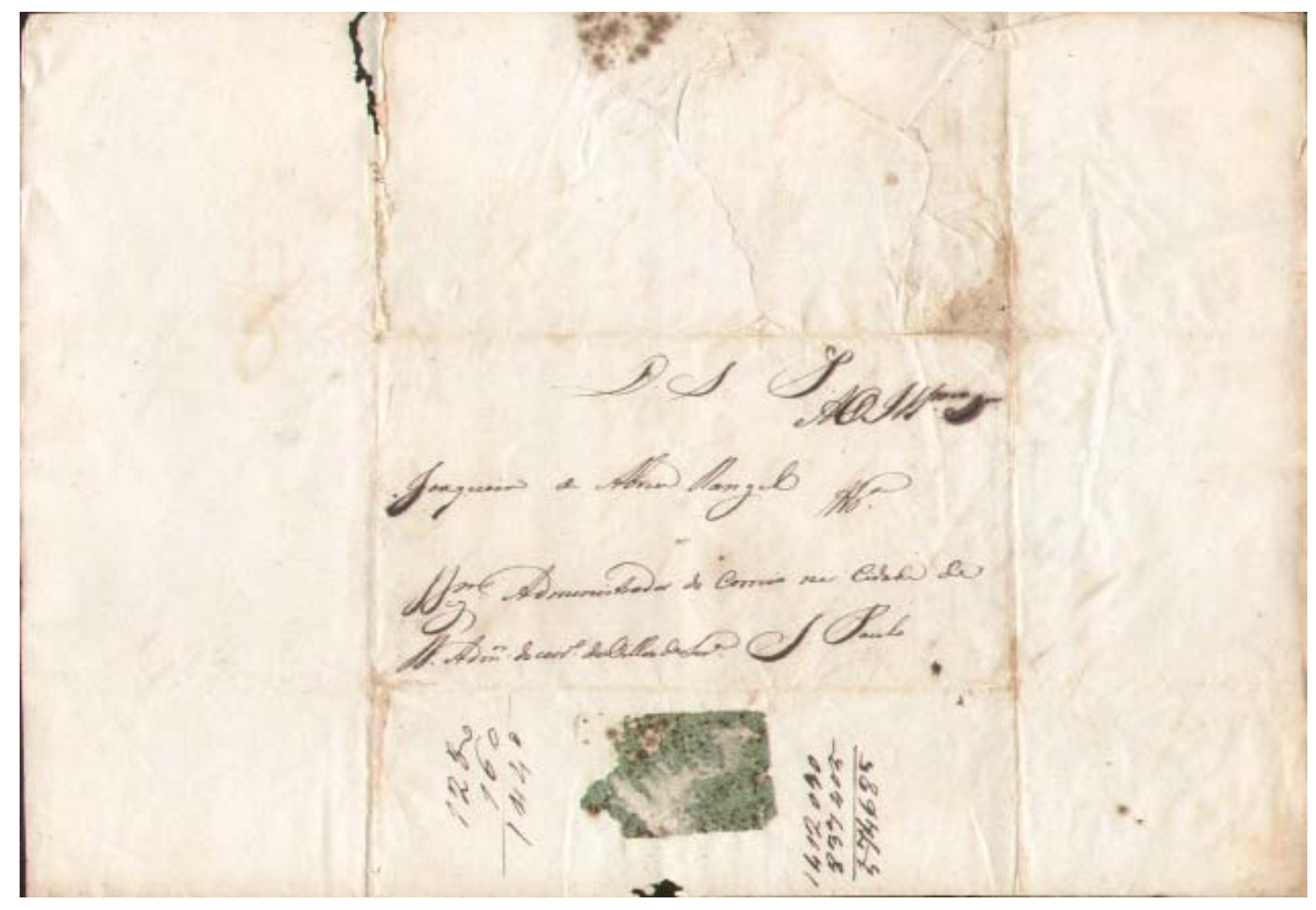


||1r.|| Ao Illustrissimo Senhor

Joaquim de Abraaõ Rangel

Illustrissimo Administrador de Correio na Cidade de

\section{Saõ Paulo}

A Administrador de Correio da Villa de Lorena

$<1280^{6}$

160

$1440>$
$<1412090$

839495

$574685>$

${ }^{6}$ Marca de selo entre as marcações numéricas, presente na linha 06. 


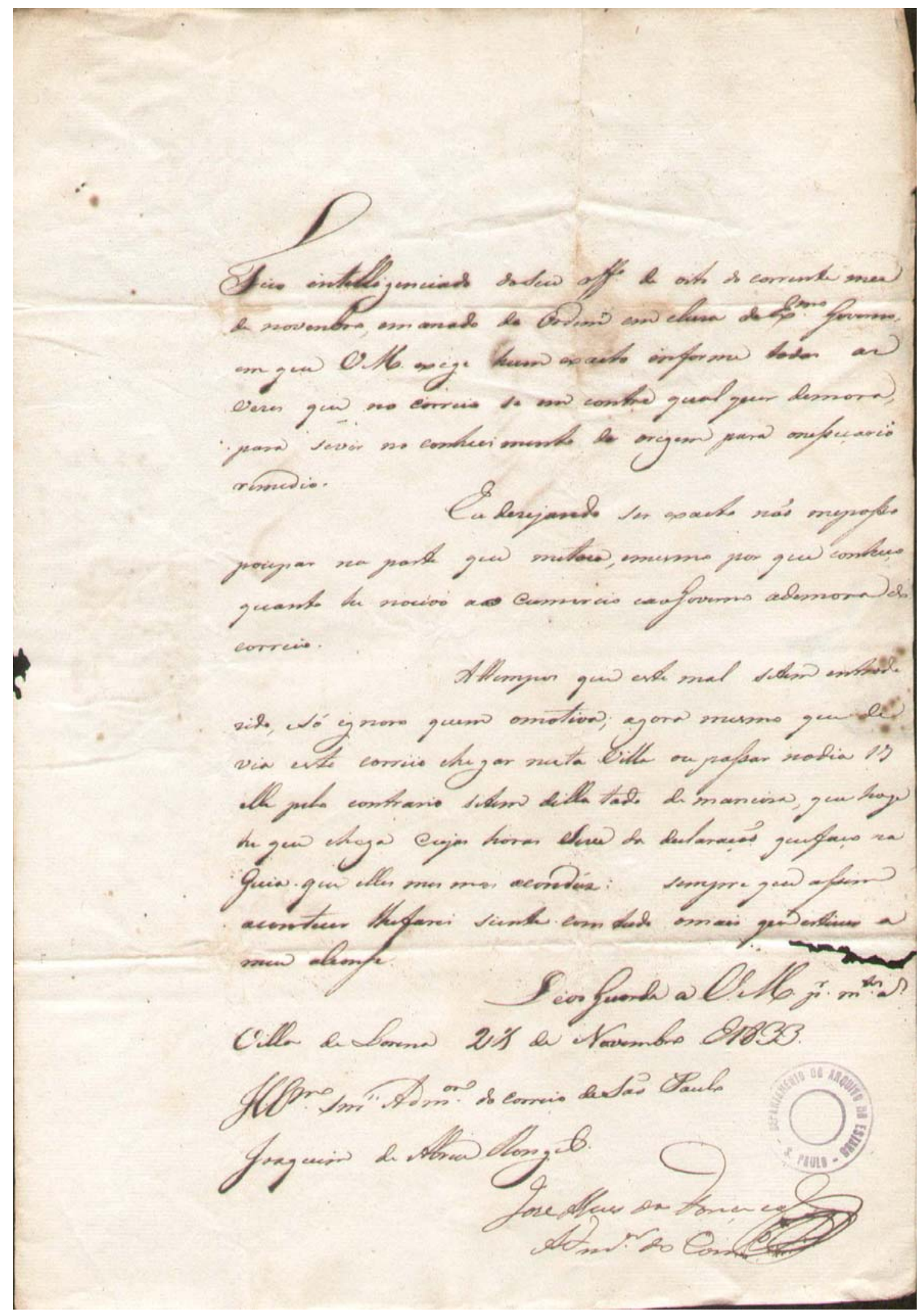


||1v.|| Fico intelligenciado doseu officio de oito do corrente mes de novembro, em xarado de ordem emclusa doExcellentissimo Governo, em que Vossa Magestade exige hum exacto informe todas as vezes que no correio se em contra qual quer demora,

5 para servir no conhecimento da origem para onesseçario remedio.

Eu desejando ser exacto naõ meposso poupar na parte que metoca, emesmo por que conheço quanto he nocivo ao comercio eaoGoverno ademora do 10 correio.

A ttempos que este mal setem entrodu zido, só ignoro quem omotiva; agora mesmo que de via este correio chegar nesta Villa ou passar nodia 14 elle pelo contrario setem dilla tado de maneira, que hoje

15 he que chega cujas horas serve da declaraçaõ quefaço na guia que elles mesmos acondúz: [espaço] sempre que assim acontecer lhefarei siente com tudo omais que estive a meu alcanse.

Deos Guarde a Vossa Magestade por muitos annos

20 Villa de Lorena 27 de Novembro de 1833.

Illustrissimo Senhor Administrador do Correio de Saõ Paulo ${ }^{7}$ Joaquim Abraõ Rangel

Jose Alves da Fonçeca [Jose Alues da Fonçeca] Administrador do Correio

\footnotetext{
${ }^{7}$ Carimbo do Arquivo do Estado de São Paulo, sito no fim da linha 21, canto inferior direito.
} 
Documento 02: encaminhado pela Diretoria Geral dos Correios do Rio de Janeiro para o presidente da província de São Paulo, em 2 de janeiro de 1868. Solicitação de criação de nova postal

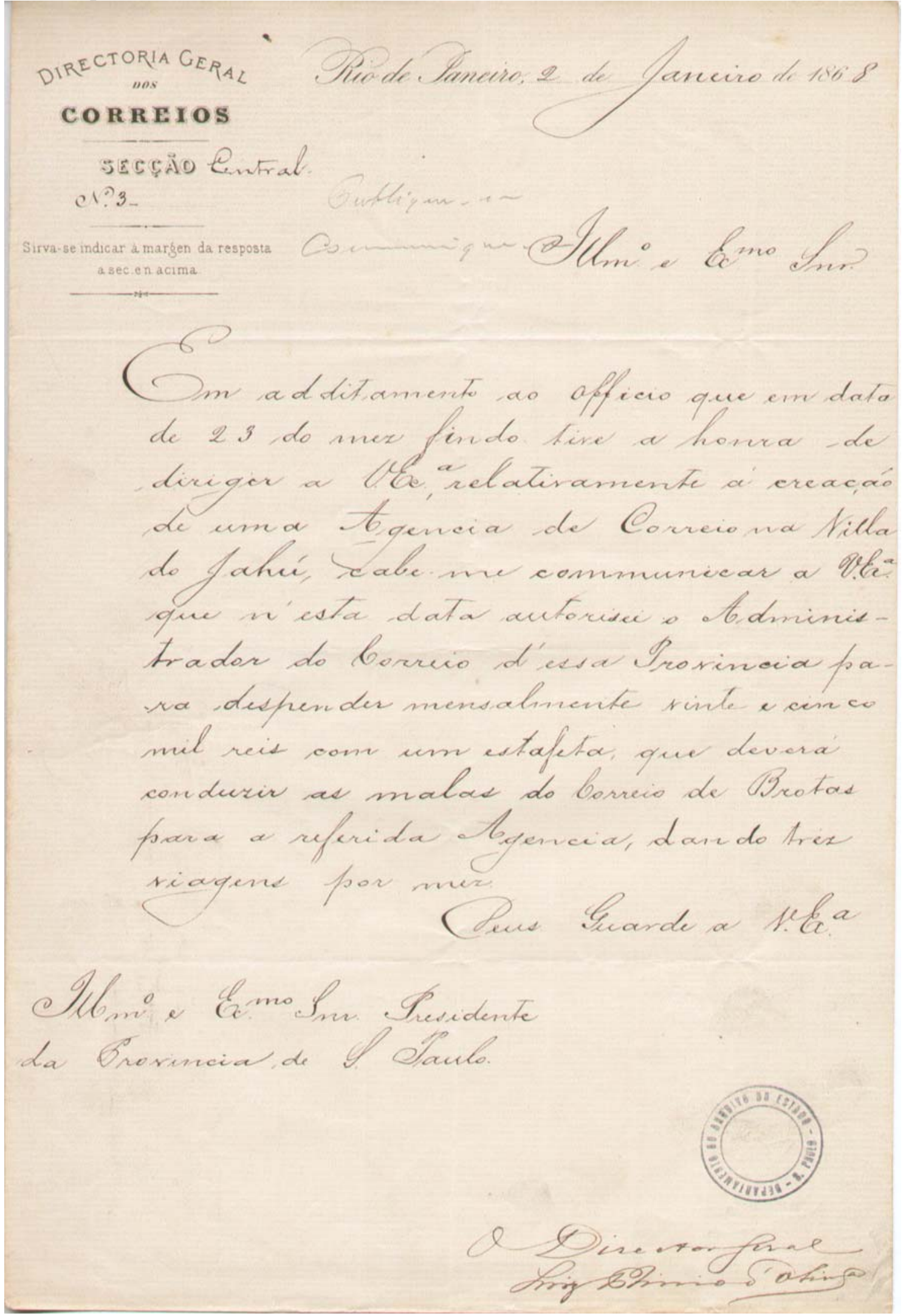


\|1r $\|^{8}$ Rio de Janeiro, 2 de Janeiro de 1868.

$<$ Central $>$

Numero $<3>$

Illustrissimo e Excellentissimo Senhor

$5 \quad{ }^{9}$ Em additamento ao officio que em data

de 23 do mez findo tive a honra de

dirigir a Vossa Excellencia, relativamente á creação

de uma Agencia de Correio na Villa

de Jahú, cabe-me communicar a Vossa Excellencia

10 que n'esta data autorisei o Adminis-

trador do Correio d'essa Provincia pa-

ra despender mensalmente vinte e cinco

mil reis com um estafeta que deverá

conduzir as malas do Correio de Brotas

15 para a referida Agencia, dando trez

viagens por mez.

Deus Guarde a Vossa Excellencia

Illustrissimo e Excellentissimo Senhor Presidente

da Provincia de São Paulo ${ }^{10}$

20

O Director Geral

Luiz B. Lima d'aSilva

8 Timbre da Directoria Geral dos Correios, com número de seção e número de documentos apostos no manuscrito entre colchetes angulares. Ao fim do timbre há a seguinte dizer Sirva-se indicar à margem da resposta a secção e número acima.

9 Informação inserida por terceiros na linha 5 com os dizeres Publique-se e Comunique-se

${ }^{10}$ Ao lado esquerdo, entre a despedida e a assinatura há carimbo circular do Arquivo do Estado de São Paulo 
Documento 03: enviado ao Presidente da Província de São Paulo, no dia 14 de julho de 1879. Trata-se de posicionamento sobre a negação de transporte por parte das companhias férreas.

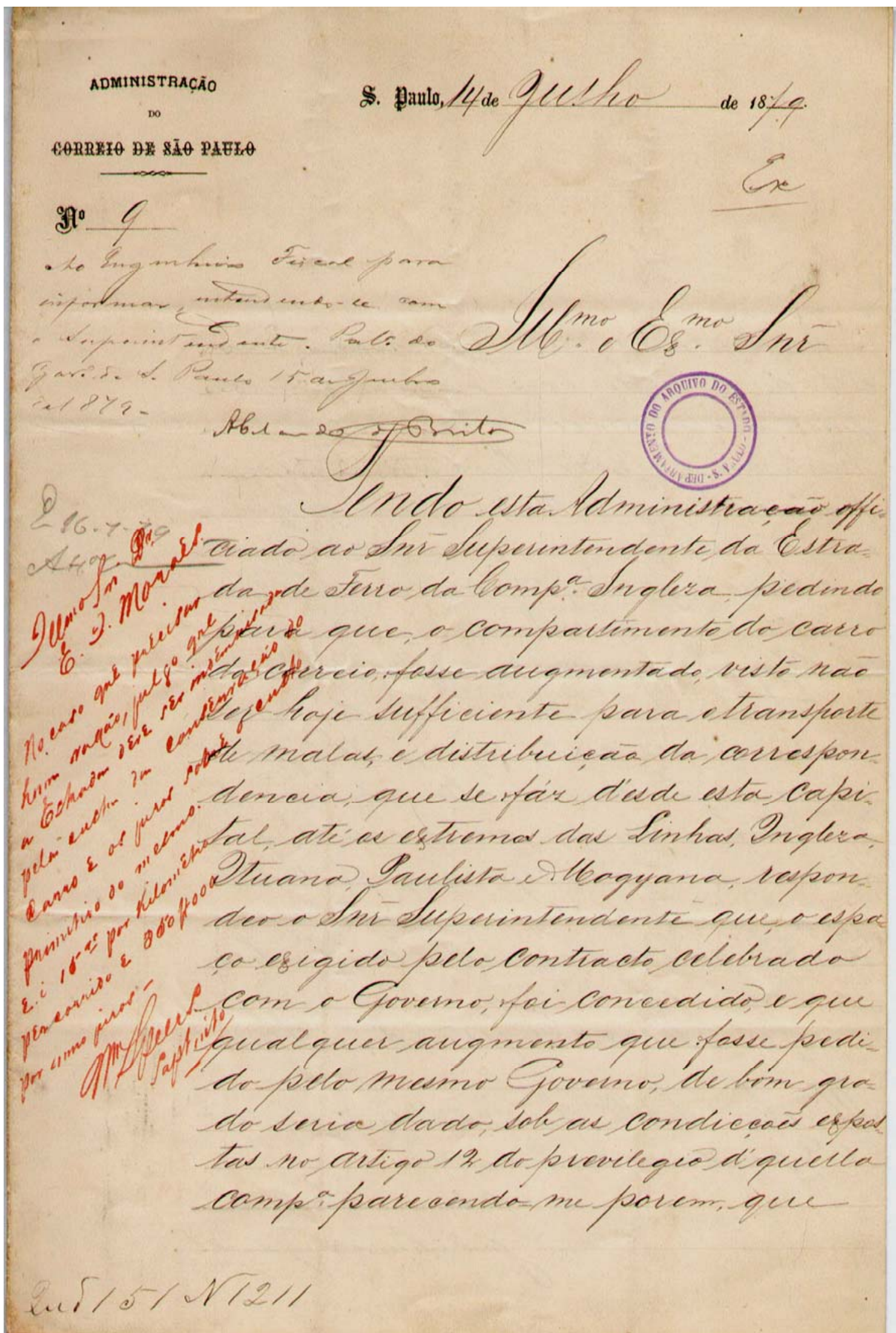


\|1r. $\|^{11} \quad$ São Paulo, 14 de julho de 1879.

Numero 09

${ }^{12}$ llustrissimo e Excellentissimo Senhor ${ }^{13}$

Tendo esta Administraçaõ offi

$5{ }^{14}$ ciado ao Senhor Superintendente da Estra

da de Ferro da Companhia Ingleza pedindo

para que o compartimento do carro

do correio, fosse augmentado, visto não

ser hoje sufficiente para o transporte

10 de malas, e distribuiçaõ da correspon

dencia, que se fáz d'esde esta capi

tal, até os extremos das Linhas, Ingleza,

Ituana, Paulista e Mogyana, respon

deo o Senhor Superintendente que, o espa

15 ço exigido pelo contracto celebrado

com o Governo, foi concedido, e que

qualquer augmento que fosse pedi

do pelo mesmo Governo, de bom gra

do seria dado, sob as condicçoẽs expos

20 tas no artigo 12 do privilegio d'aquella

Companhia parecendo-me porem, que ${ }^{11}$

11 Timbre da Administração do Correio de São Paulo com número de documento, expresso no manuscrito.

${ }^{12}$ Informação de terceiros presente entre as linhas 3 e 7 com os dizeres Ao Engenheiro Fiscal/ para informar, entendendo-se com/ o Superintendente Postal do /Governo de São Paulo. 15 de junho/ de 1879. Abelardo de Brito

${ }^{13}$ Carimbo Circular do Arquivo do Estado de São Paulo aposto entre a evocação e o início do texto do documento

${ }^{14}$ Informação de terceiros aposta na margem esquerda de leitura do escriba com o dizeres Illustrissimo Senhor/Eduardo Jose de Moraes/No caso que precisar/hum vagão, julgo que/a Estrada deve ser indemnisada/pelas custas de conservação do/Carro e os juros sobre o custo/primitivo do mesmo./E.i. 18 reis por kilomêtro/percorrido e $280 \$ 000 /$ por anno juros

${ }^{11}$ Informação inserida por terceiros na margem esquerda com os dizeres 2ud151Número1211 
a espivito da veridas condiceceo nao atá de acearda can a acankadi com paltimente coneedide bela campi na parte em que dex" de a Govemo efigir para ute devieo, thaiar eppa er do nue a de un lliagon gue pede accommoda deie saraia a comp: fonved a ba me diante una indeminacas per pate do Govene, no cado contiacie, foven empugavá cauror tead; arvita dieto ves peitoramiente venter logar a ICó paia que de digne, in leva alta dabedoua to mar ab providencial que o cavo efiges, farendo com que lefa augmentadoo spaco que a eluatinente diepar a cal

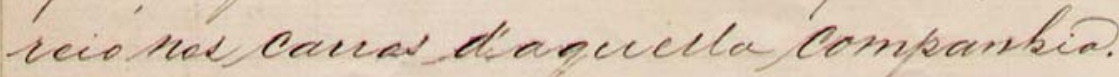

\section{Qcesteravde ales:}

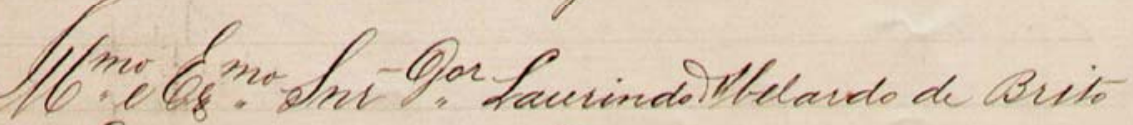
H. Q Praidonte da Movereia.

\section{Octdministrados interines}

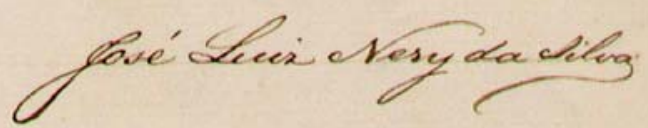


||1v.||o espirito da referida condicçaõ naõ

está de accordo com o acanhado com

partimento concedido pela companhia; na

25 parte em que diz "Se o Governo exigir

para este serviço, maior espaço do que

o de um wagon que possa accomodar

seis pessôas, a companhia fornecel-o-ha me

diante uma indemnizaçaõ por parte

30 do Governo, no caso contrario, o Governo

empregará carros seos"; a vista disto, res=

peitozamente venho rogar a Vossa Excellencia para

que se digne, em sua alta sabedoria, to $=$

mar as providencia que o caso exige,

35 fazendo com que seja augmentado o

espaço que actualmente dispoẽ o cor

reio nos carros d'aquella companhia.

Deus Guarde a Vossa Excellencia

Illustrissimo e Excellentissimo Senhor Doutor Laurindo Abelardo de Brito

40 Muitissimo Dignissimo Presidente da Provincia

$<\mathrm{O}$ Administrador interino $>$

$\underline{\text { José Luiz Nery da Silva }}$

45

50 
Documento 04: partiu da Companhia de Estrada de Ferro de Santos a Jundiahy informando sobre as despesas com o transporte de cartas e redução de indenização por perda ou extravio.

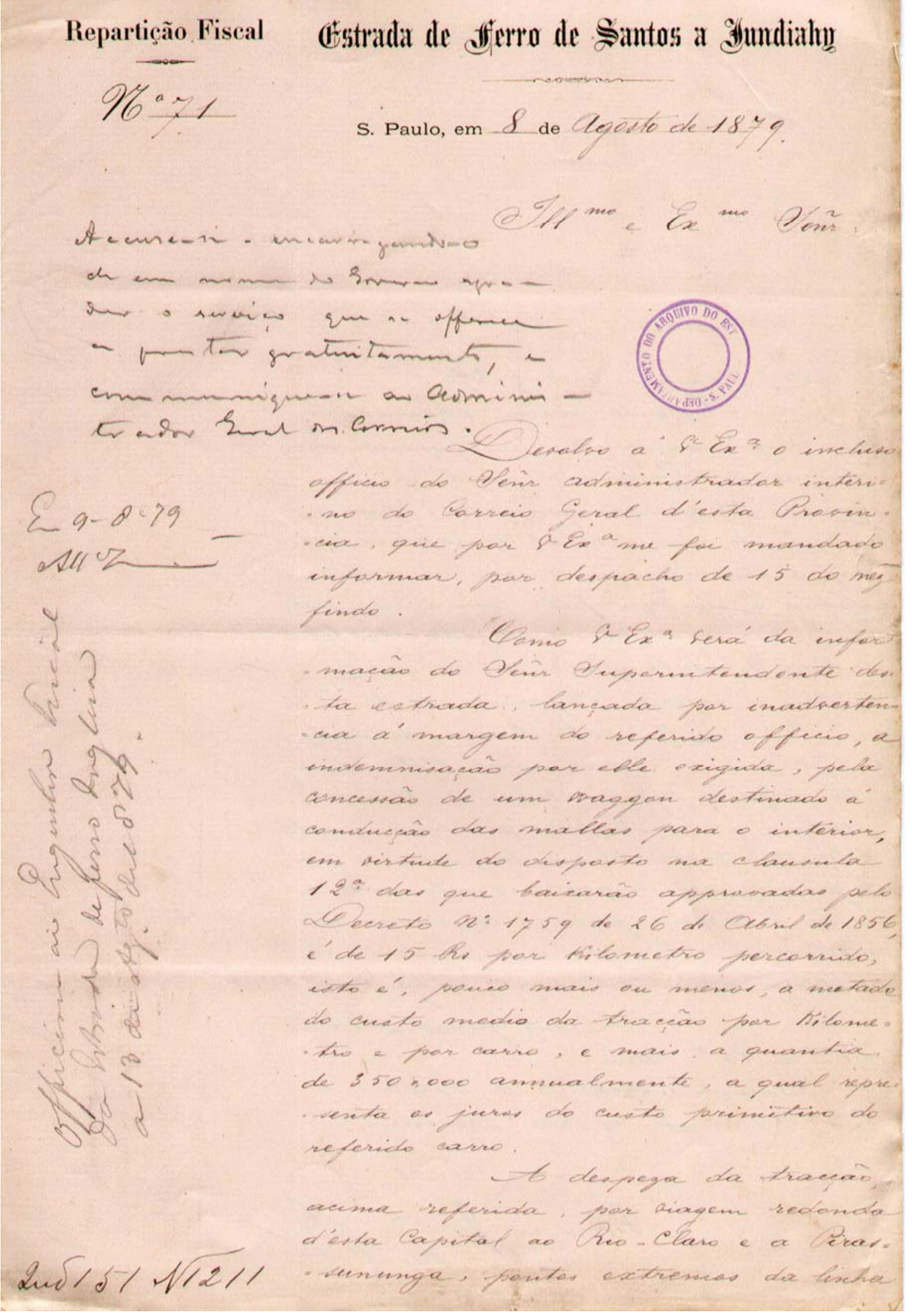


||1r.|| Numero $71^{15}$

São Paulo, em 08 de agosto de 1879.

Illustrissimo e Excellentissimo Senhor ${ }^{16}$

${ }^{17}$ Devolvo á Vossa Excellencia o incluso

5 officio do Senhor administrador interi=

=no do Correio Geral d'esta Provin=

${ }^{18}=$ cia, que por Vossa Excellencia me foi mandado

informar, por despacho de $15 \mathrm{do} \mathrm{mez}$

findo.

1019 Como Vossa Excellencia será da informa-

=mação do Senhor Superintendente des=

=ta estrada, lançada por inadverten=

=cia á margem do referido officio, a

indemnisação por elle exigida, pela

15 concessão de um waggon destinado á

conducção das mallas para o interior,

em virtude do disposto na clausula

Decima segunda das que baixarão approvadas pelo

Decreto numero 1759 de 26 de Abril de 1856,

20 é de 15 Reis por kilometro percorrido, isto é, pouco mais ou menos, a metade do custo médio da tracção por kilome= $=$ tro e por carro, e mais a quantia de $350 \$ 000$ annualmente, a qual repre $=$

$25=$ senta os juros do custo primitivo do referido carro.

A despeza da tracção, acima referida por viagem redonda d'esta Capital ao Rio - Claro e a Piras= sununga, pontos extremos da linha

${ }^{15}$ Timbre da Repartição Fiscal, com numeração aposta no documento e na mesma linha timbre da Estrada de Ferro de Santos a Jundiahy

${ }^{16}$ Carimbo circular do Arquivo do Estado de São Paulo presente no lado direito do documento entre o tratamento e o início do texto.

${ }^{17}$ Informação de terceiros localizada na margem esquerda do documento, localizado em ter a evocação e o inicio do ofício, com os seguintes dizeres Acuse-se encarregando-o/ de em nome do Governo apreen/ der o serviço que se offerece/ a prestar gratuitamente, e/ communique-se ao Adminis/ trador Geral dos Correios.

${ }^{18}$ Informação de terceiros, localizada na margem esquerda do documento, com os dizeres Em 09/08/79

19 Informação de terceiros, localizada na margem esquerda, horizontalmente ao corpo do ofício que informa Officina do Engenheiro Fiscal/ da Estrada de Ferro Ingleza/ a 13 de Agosto de 1879. 
d'eate, ievama a he $7+875$.

C Endo, parein, abresvado ao

Qenis Peepernetendente que, deippando ace

- tuabuente o Gareneo de parte de un

sargan (1/s appraximadamente), eame a

cancervio do equaco total do referedo sug.

- pon, a indenenvercáa derevia der apenas

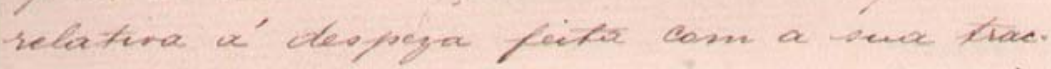

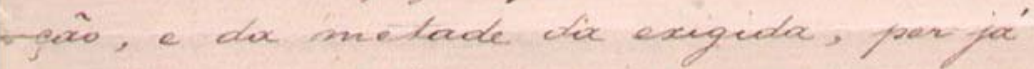

reatian-se deturenente, no que con-

- carcier o seferido Puperintendente. If ester tesmes, redugida

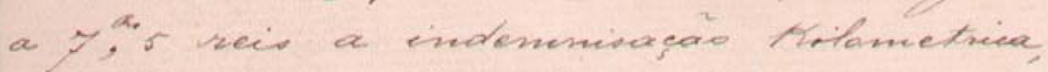
eita despega vena inferiar a loob000

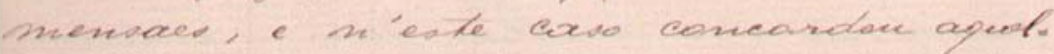
- 1 Henperintendente, en augnenter den - de ja'o eqvapo de que cectualmende despoe o Carsicio fura a canderecaio der mexlear do interior, independente de qualquen onew por parte do jeveno.

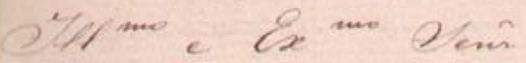

Llar jearde a bie?

(6) : naverindo CBClardo da Dibito

(6) un previderete of edta Propincia.

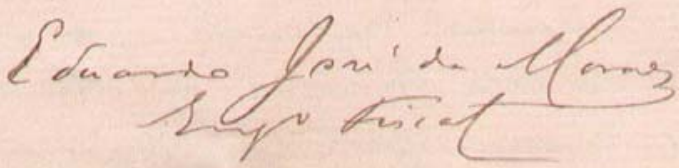


||1v.||d'Oeste, s'elevaria a 7\$875 Reis.

Tendo, porém, observado ao

Senhor Superintendente que, dispondo $\mathrm{ac}=$

$=$ tualmente o Governo de parte de um

35 waggon (1/3 approximadamente), com a

concessão do espaço total do referido wag=

gon, a indemnisação deveria ser apenas

relativa á despeza feita com a sua trac $=$

=ção, e da metade exigida, por já

40 realisar-se actualmente, no que con-

-cordou o referido Superintendente.

N'estes termos, reduzida

a 700,5 reis a indemnisação kilometrica, esta despeza seria inferior a $100 \$ 000$

45 mensaes, e n'este caso concordou aquel= $=$ le Superintendente, em augmentar des $=$ =de já o espaço de que actualmente dispõe o correio para a conducção das mallas do interior, independente de

50 qualquer onus por parte do Governo.

Deus Guarde a Vossa Excellencia

Illustrissimo e Excellentissimo Senhor

Doutor Laurindo Abelardo de Brito

Dignissimo Presidente d'esta Provincia.

55

$\underline{\text { Eduardo José de Moraes }}$

Superintendente Fiscal 
Documento 05: Manuscrito destinado à Presidência da Província de São Paulo, datado de 26 de Março de 1881. O assunto é sobre o roubo de malas do Correio.

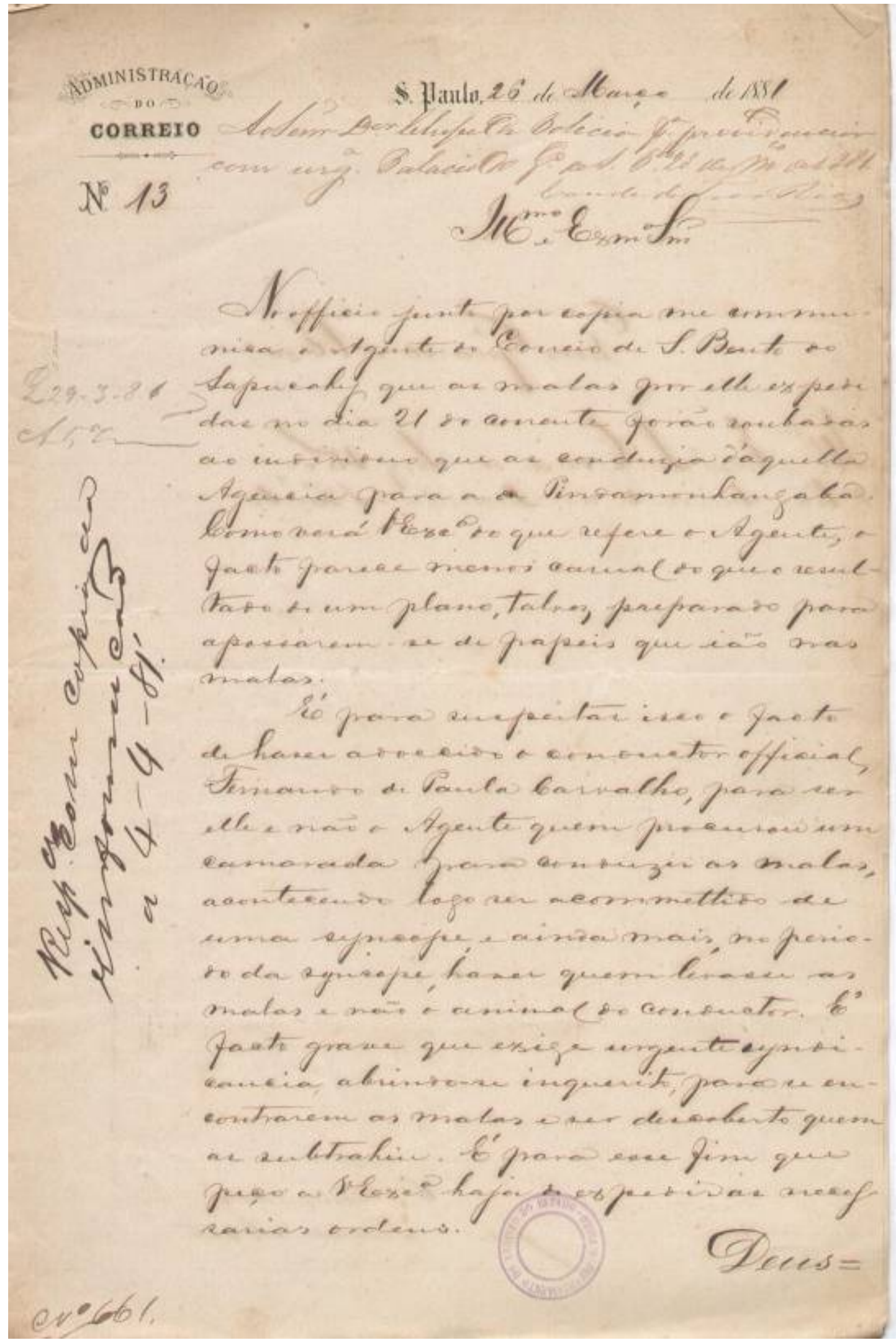


$\|1 \mathrm{r} .\|^{20}$ Sã̃ Paulo, 26 de Março de 1881.

${ }^{21}<$ Numero $13>$

Illustrissimo e Excellentissimo Senhor

No officio junto por copia me commu-

5 nica o Agente do Correio de São Bento do

${ }^{22}$ Sapucahy que as malas por elle expedi

das no dia 21 do corrente foraõ roubadas

do individuo que as conduzia d'aquella

Agencia para a de Pindamonhangaba.

10 Como verá Vossa Excellencia do que refere o Agente, o

facto parece menos casual do que o resul-

tado de um plano, talvez, preparado para

apossarem-se de papeis que iaõ nas

malas.

$15{ }^{23}$ É para suspeitar isso o facto

de haver adoecido o conductor official,

Fernando de Paula Carvalho, para ser

elle e naõ o Agente quem procurou um

camarada para conduzir as malas,

20 acontecendo logo ser acommettido de

uma syncope e ainda mais, no pero-

do da syncope, haver quem levasse as

malas e não o animal do conductor. É

facto grave que exige urgente syndi-

25 cancia abrindo-se inquerito, para se en-

contrarem as malas e ser descoberto quem

as subtrahiu. É para esse fim que

peço a Vossa Excellencia haja de expedir as neces-

sarias ordens. ${ }^{24}$

$30{ }^{25}[$ espaço]Deus=

20 Timbre da Administração do Correio, no canto superior esquerdo do documento, acompanhado de n[úmero de documento.

${ }^{21}$ Informação de terceiro localizada após a linha de datação e antes antecedente a evocação, com os seguintes dizeres Ao Senhor Doutor Chefe de Policia para providencias/ com urgência Palácio do Governo de São Paulo, 28 de Março de 1881/ Conde de Trez Rios

22 Anotação tardia de terceira feita a lápis na margem esquerda do documento: Expedido 29-3-81/ A quinta [Seção]

${ }^{23}$ Informação de terceiros, localizada na margem esquerda do documento, horizontalmente ao corpo do ofício, com os seguintes dizeres: Resposta com copia da/informaçaõ/a 4- 4-81

${ }^{24}$ Carimbo circular do Arquivo do Estado de São Paulo, situado logo abaixo da última linha do documento.

${ }^{25}$ Informação de terceiros no rodapé lateral direito do documento com os dizeres Numero 661 
113

Dus Guande a tese-

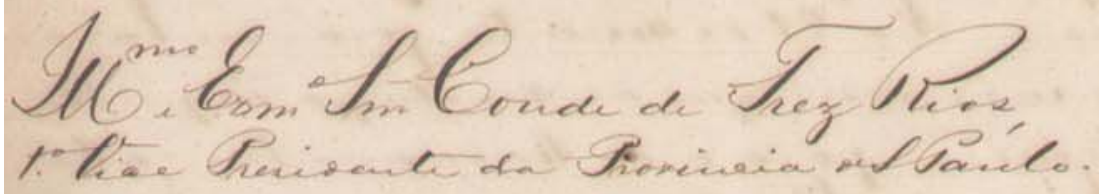

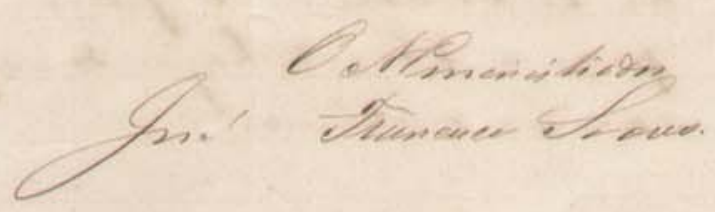




\section{Deus Guarde a Vossa Excellencia}

Illustrissimo e Excellentissimo Senhor Conde de Trez Rios,

Primeiro Vice Presidente da Provincia de São Paulo

O Administrador 
Documento 06: Manuscrito destinado à presidência da província de São Paulo, datada de 11 de março de 1883, que trata da violação de correspondências.

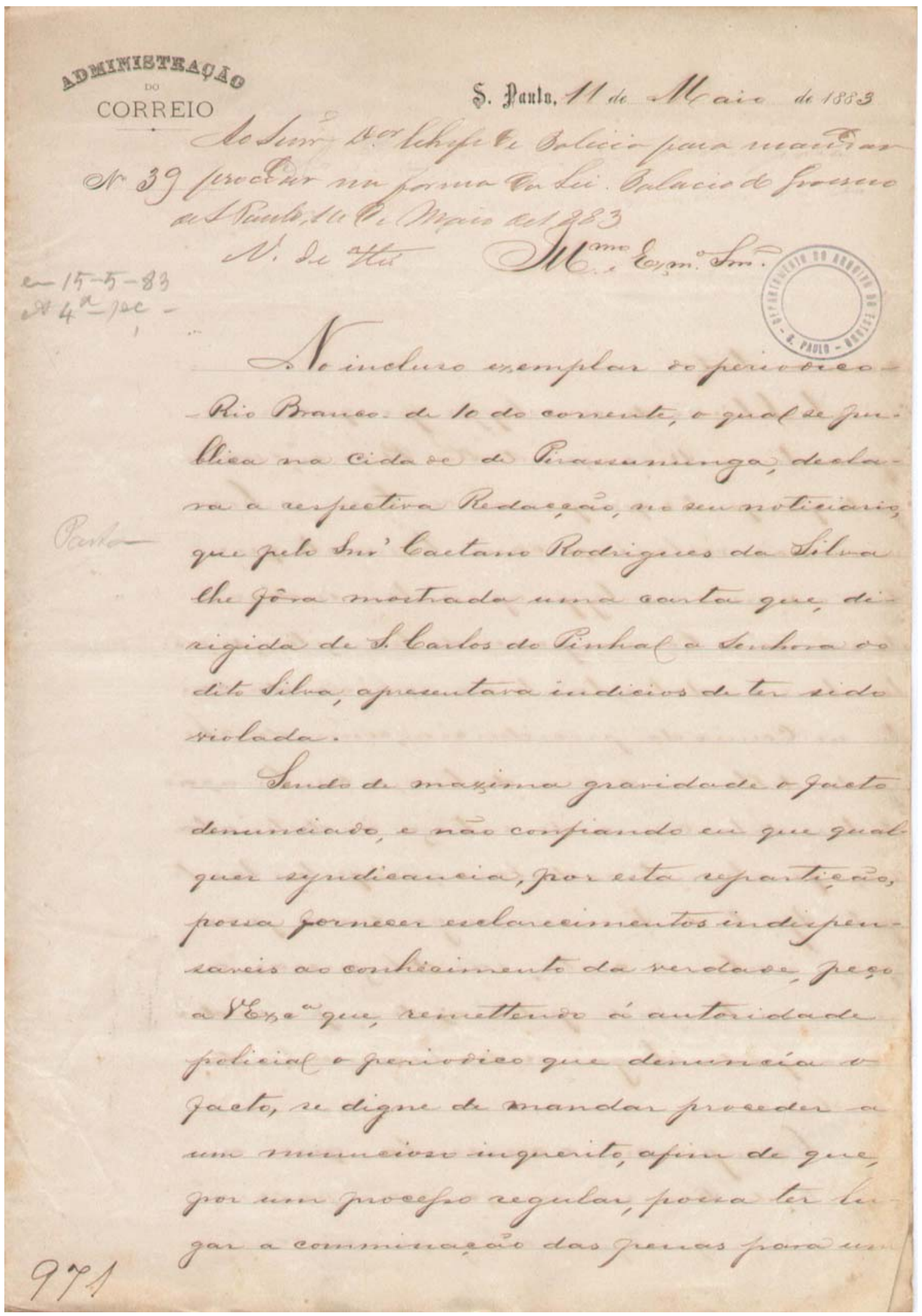


||1r.| ${ }^{26}$ São Paulo, 11 de Maio de 1883

${ }^{27} \leq$ Numero39>

Illustrissimo e Excellentissimo Senhor ${ }^{28}$

No incluso exemplar do periodico $-{ }^{29}$

5 -Rio Branco de 10 do corrente, o qual se pu-

blica na cidade de Pirassununga, decla-

ra a respectiva Redaçaõ, no seu noticiario,

que pelo Senhor Caetano Rodrigues da Silva

lhe fôra mostrada uma carta que, di-

10 rigidia de São Carlos do Pinhal a Senhora do

dito Silva, apresentava indicios de ter sido

violada.

Sendo de maxima gravidade o facto

denunciado, e não confiando eu que qual-

15 quer syndicancia, por esta repartição,

possa fornecer esclarecimentos indispen-

saveis ao conhecimento da verdade, peço

a Vossa Excellencia que, remettendo á autoridade

policial o periodico que denuncía o

20 facto, se digne de mandar proceder a

um minucioso inquerito, afim de que,

por um processo regular, possa ter lu-

gar communicação das pessoas para um ${ }^{30}$

${ }^{26}$ Timbre a Administração do Correio presente no canto superior esquerdo do documento com numeração de documento aposto na transcrição.

${ }^{27}$ Informação de terceiro localizada abaixo da datação e acima da evocação com os dizeres Ao Senhor Doutor Chefe de Policia para mandar/processar na forma da Lei. Palacio do Governo/ de São Paulo, 10 de maio de 1883/Visconde de Itu

${ }^{28}$ Anotação tardia de terceiro feita a lápis e aposta na margem esquerda do documento, logo abaixo do despacho do Visconde de Itu: em 15-5-83/ A Quarta Seção

${ }^{29}$ Carimbo circular do Arquivo do Estado de São Paulo presente entre o tratamento da carta e seu texto, no lado superior direito do documento, abaixo da evocação.

${ }^{30}$ Informação tardia de terceiro, situada na margem inferior esquerda com a seguinte informação: 971 
arine tor.

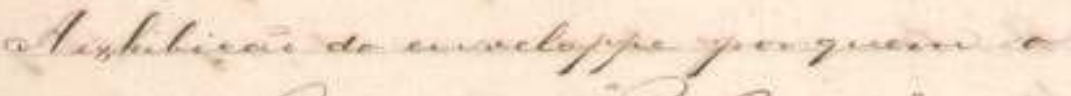

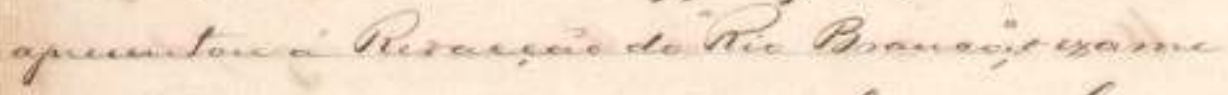

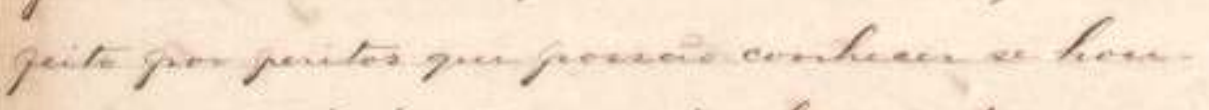

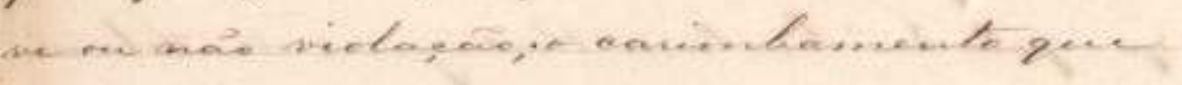

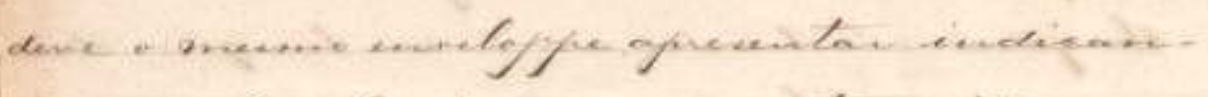

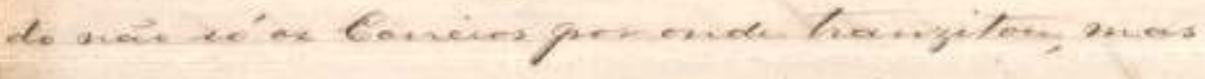

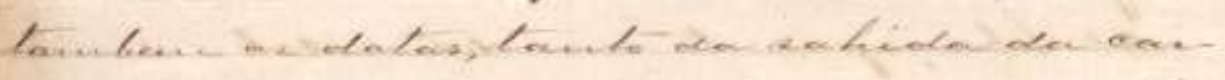

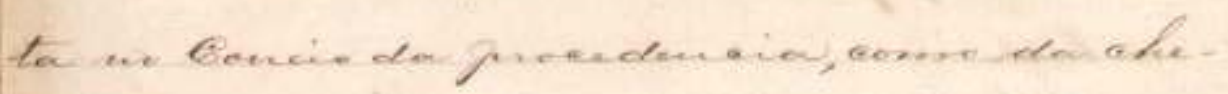

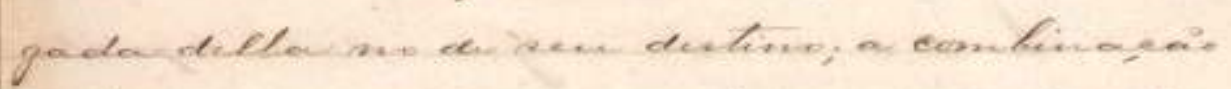

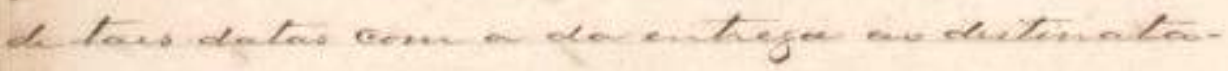

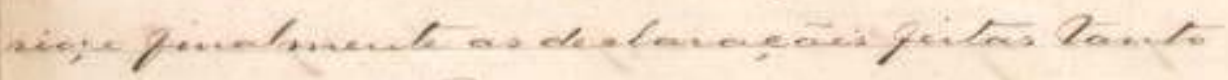

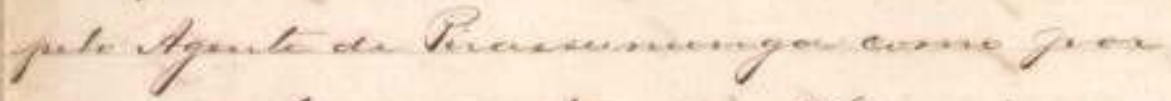

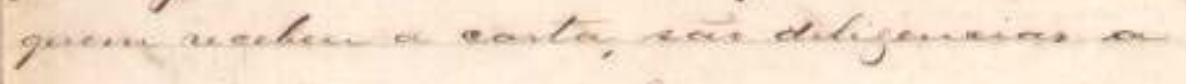

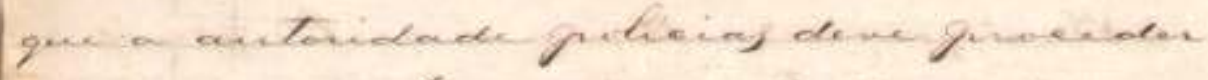

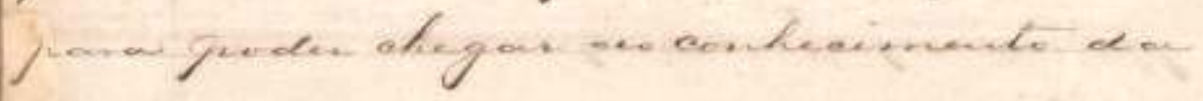

heridare.

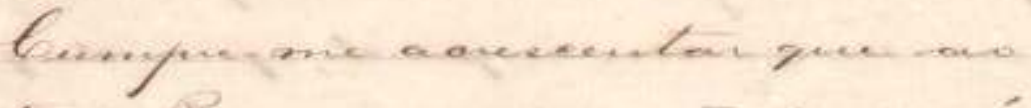

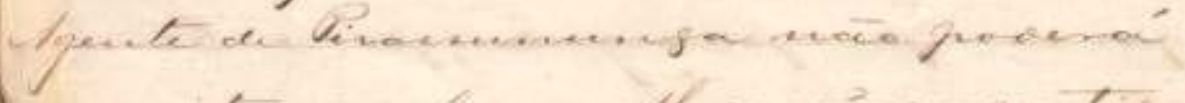

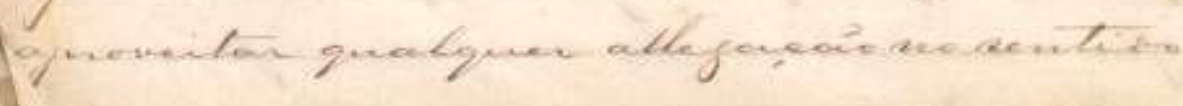


\|1v. || crime tal.

25

A exhibição do enveloppe por quem o

apresentou á Redacção do "Rio Branco"; o exame

feito por peritos que possão conhecer se houve ou não violação; o carimbamento que

deve o mesmo enveloppe apresentar indican-

30 do não só os Correios por onde tranzitou, mas

tambem as datas, tanto da sahida da car-

ta no Correio da procedencia, como da che-

gada della no de seu destino; a combinação

de taes datas com a da entrega ao destinata-

35 rio; e finalmente as declarações feitas tanto

pelo Agente de Pirassununga como por

quem recebeu a carta, são deligencias a

que a autoridade policial deve proceder

para poder chegar ao conhecimento da

40 verdade.

Cumpre-me acrescentar que ao

Agente de Pirassununga não poderá

aproveitar qualquer allegação no sentido

45

50 


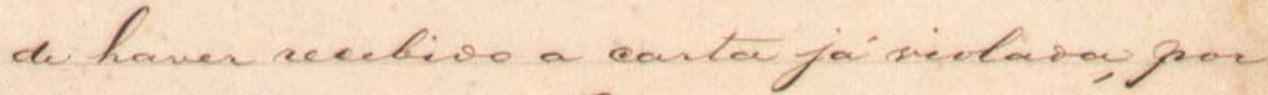

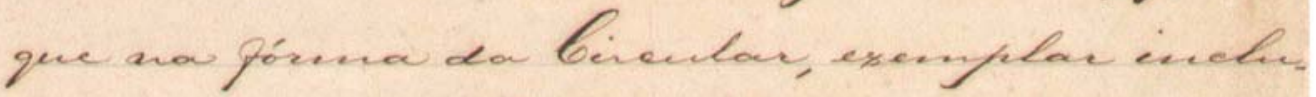

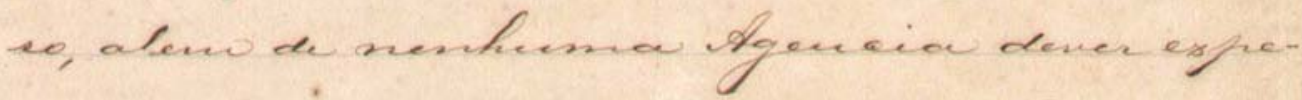

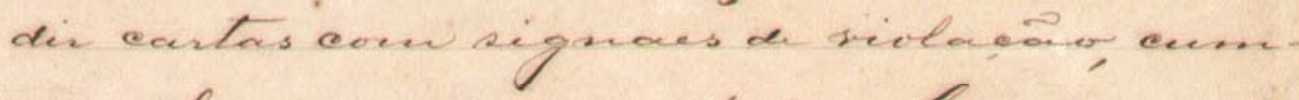

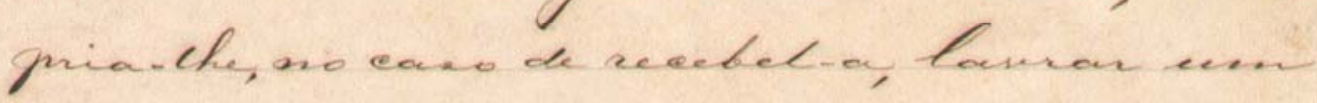

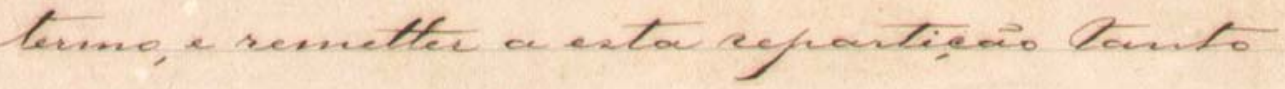
erte ropino a conta.

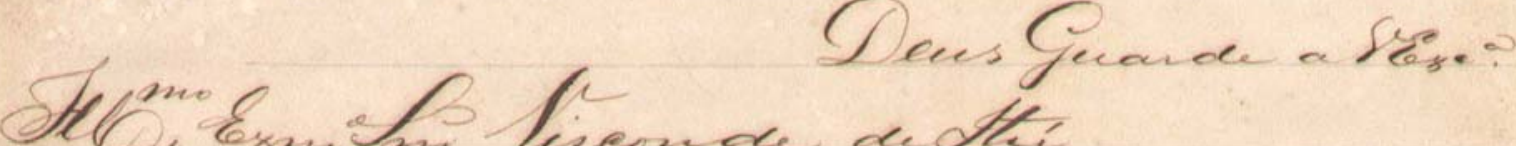

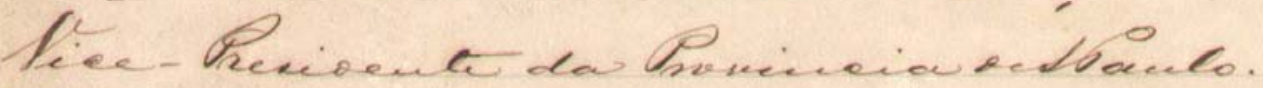
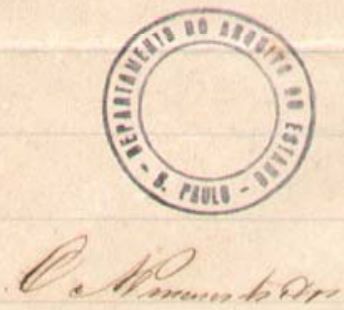

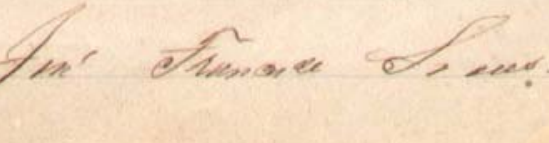


\|2r.|| de haver recebido a carta já violada, por

25 que na fórma da Circular, exemplar incluso, alem de nenhuma Agencia dever expedir cartas com signaes de violação, cumpria-lhe, no caso de recebel-a, lavrar um termo, e remetter a esta repartição tanto

30 este como a carta.

Deus Guarde a Vossa Excellencia

Illustrissimo e Excellentissimo Senhor Visconde de Itú,

Vice- Presidente da Provincia de São Paulo. ${ }^{31}$

O Administrador

José Francisco Soares

${ }^{31}$ Carimbo circular do Arquivo do Estado de São Paulo aposto acima da assinatura do Administrado, no canto inferior direito. 
Documento 07: questionamento sobre os valores de transporte das cartas, emitido em 24 de abril de 1889 da Vila de São Manoel para a província de São Paulo.

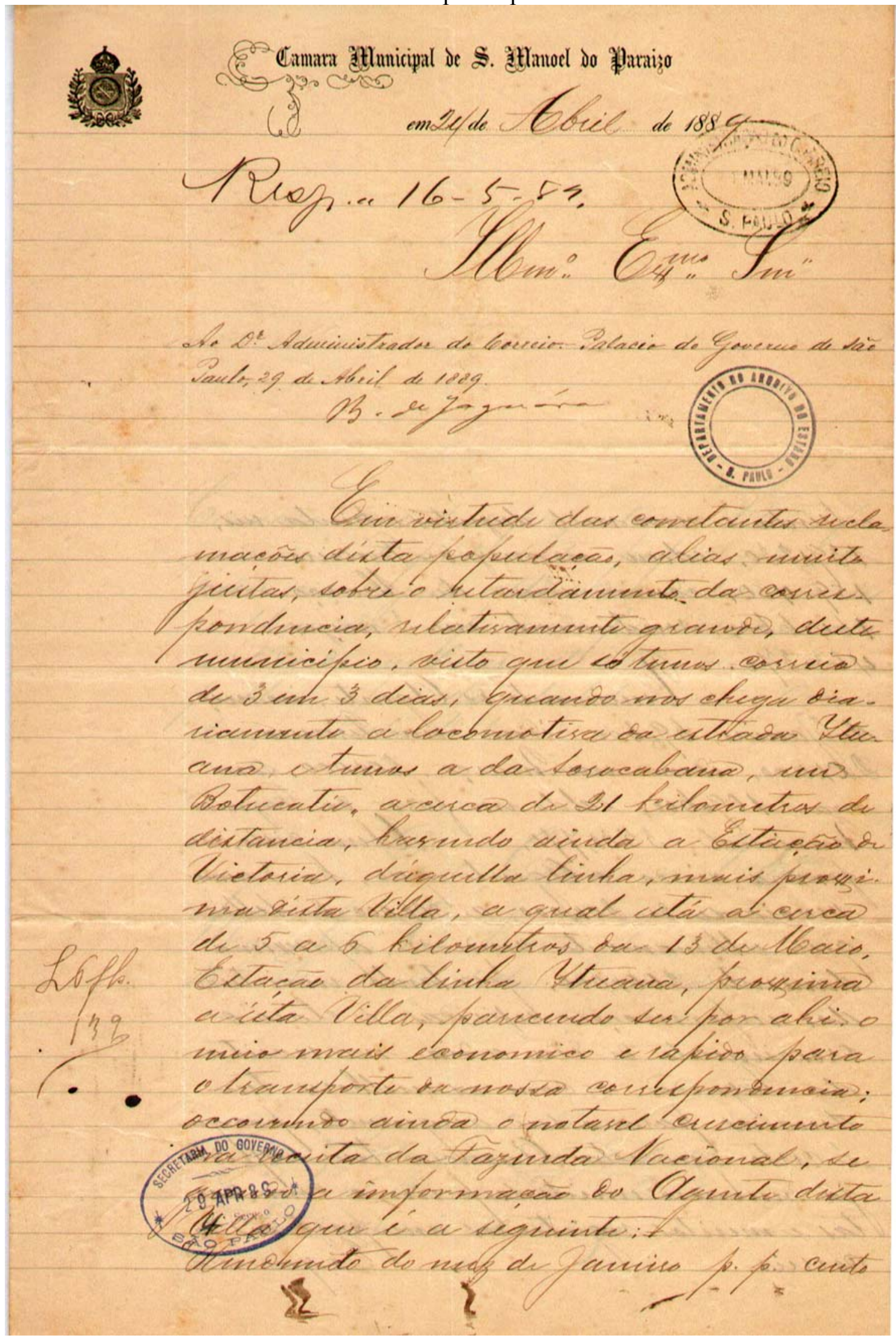




$$
\|1 \mathrm{r} .\|^{32}
$$

em 24 de Abril de 1889. ${ }^{33} 34$

Illustrissimo e Excellentissimo Senhor ${ }^{35}$

${ }^{36}$ Em virtude das constantes recla

5 mações désta população, alias muito

justas, sobre o retardamento da corres-

pondencia, relativamente grande, deste

municipio, visto que só temos correio

de 3 em 3 dias, quando nos chega dia-

10 riamente a locomotiva da estrada Ytu

ana e temos a da Sorocabana, em

Botucatú, a cerca de 21 kilometros de

distancia, havendo ainda a Estação de

Victoria, dáquella linha, mais proxi-

15 ma désta Villa, a qual está a cerca

de 5 a 6 kilometros da 13 de Maio,

Estação da linha Ytuana, proxima

a ésta Villa, parecendo ser por ahi, o

meio mais economico e rapido para

20 o transporte da nossa correspondencia; ${ }^{37}$

occorrendo ainda o notavel crescimento

na receita da Fazenda Nacional, se

guindo a informação do Agente desta

Villa que é a seguinte:

25 Rendimento do mez de Janeiro por periodo cento

\footnotetext{
32 Timbre da Camara Municipal de São Manoel do Paraizo centralizado no canto superior do documento.

${ }^{33}$ Carimbo oval da Administração do Correio situado entre a data e o tratamento inicial do documento. Na margem direita.

${ }^{34}$ Informação tardia de terceiros escrita com lápis entre a data e o tratamento inicial do documento: Respondida 1605-89

35 Informação de terceiros, localizada entre a data e a evocação em que há os seguintes dizeres: Ao Doutor Administrador de Correio Palacio do Governo de São/ Paulo, 29 de Abril de 1889/ <Barao de Jaguara>

${ }^{36}$ Carimbo circular do Arquivo do Estado de São Paulo aposto entre o tratamento inicial e o início do corpo do documento, situado na margem direita.

${ }^{37}$ Carimbo oval da Secretaria do Governo, datado de 20 de abril de 1889, aposto no canto inferior esquerdo.
} 


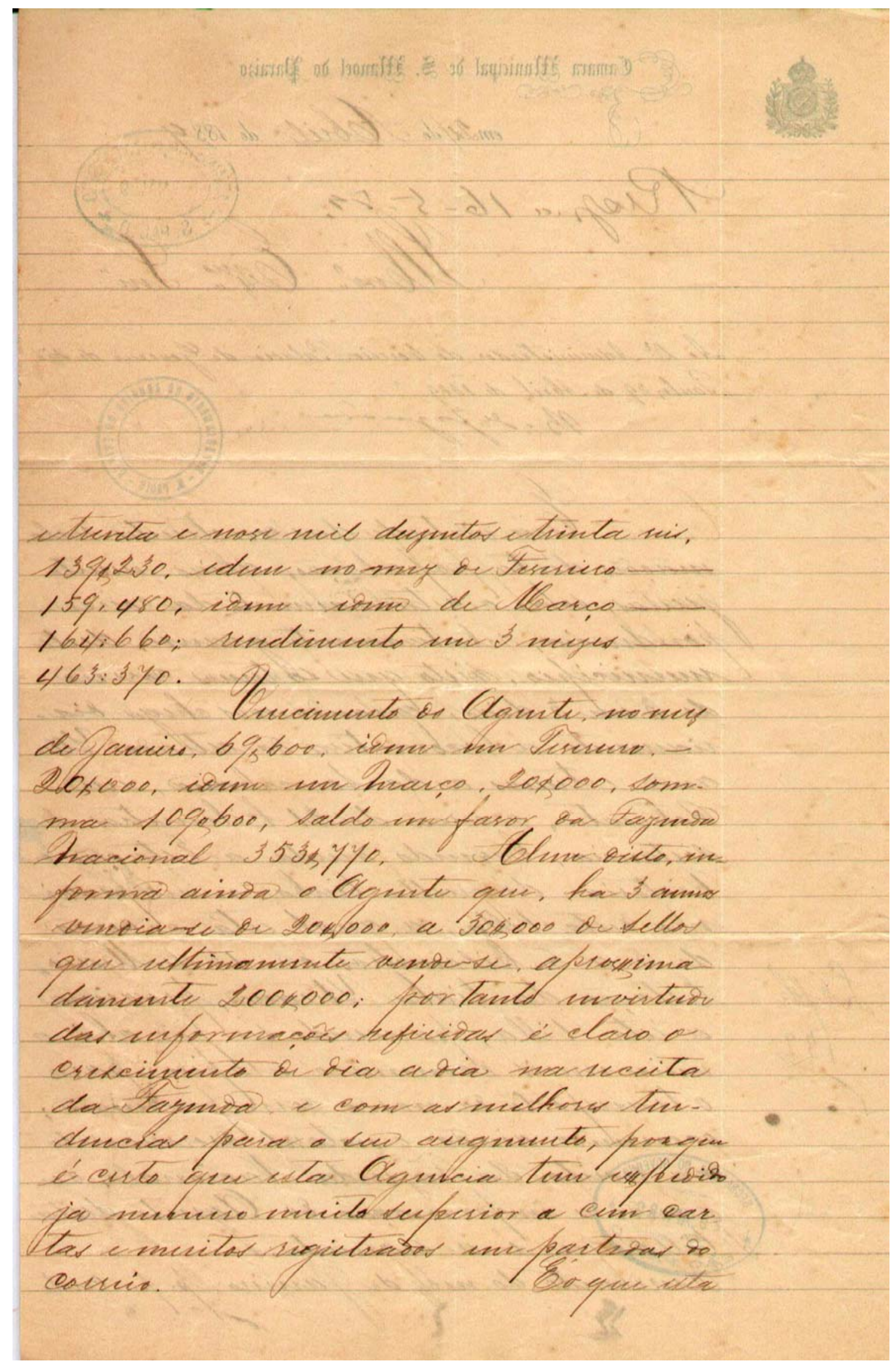


\|1v. |e trinta e nove mil duzentos e trinta seis,

139\$230, idem no mez de Fevereiro

$159 \$ 480$, idem idem de Março

164:660; rendimento em 3 mezes

$30 \quad 463: 370$

Vencimento do Agente, no mez de Janeiro, 69\$600, idem em Fevereiro. 20\$000, idem em Março, 20\$000, somma $109 \$ 600$, saldo em favor da Fazenda

35 Nacional 353\$770. [espaço] Alem disto, informa ainda o Agente que, há 3 annos vendia-se de $20 \$ 000$ a $30 \$ 000$ de sellos que ultimamente vende-se, aproxima damente 200\$000; por tanto envirtude

40 das informações definidas é claro o crescimento de dia a dia na receita da Fazenda e com as melhores tendencias par ao seu augmento, porque é certo que esta Agencia tem expedido

45 ja numero muito superior a cem car tas e muitos registrados em partidas do correio. [espaço] É o que esta 


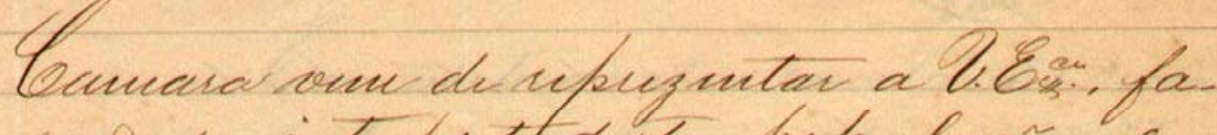

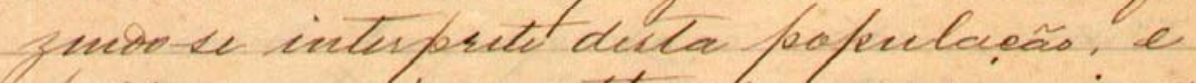

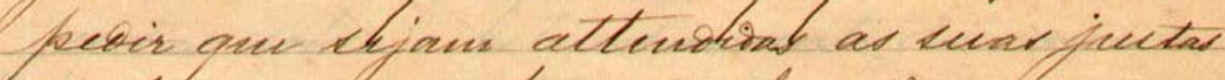

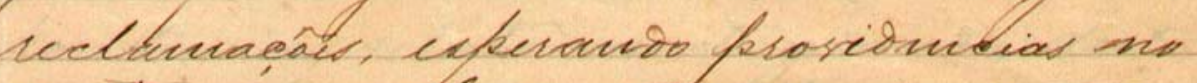

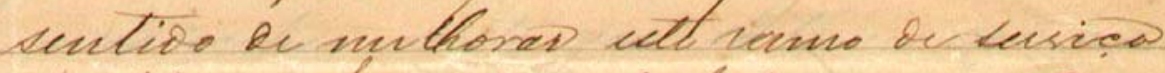
pubtico, afine de cubublecer ex o Oorrio decivo a ula Pilla

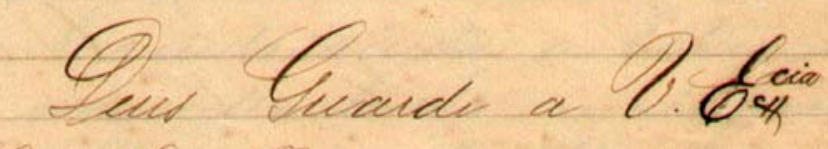

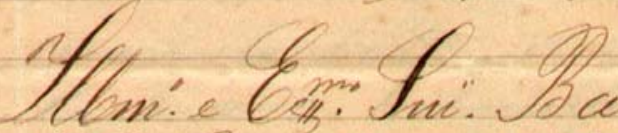

thran de aquara

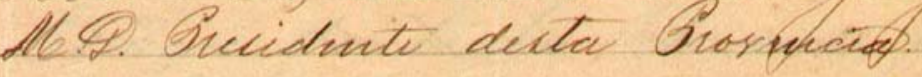

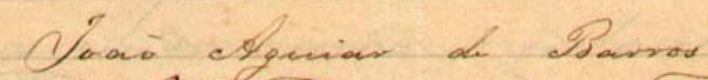

Yarig starian deatad

ye c thathies refforvida Batya

- Traño ediburio de atrauje 
||2r. | Camara vem de reprezentar a Vossa Excellencia, fazendo-se interprete desta população, e

50 pedir que sejam attendidas as suas justas reclamações, esperando providencias no sentido de melhorar este ramo de serviço publico, afim de estabelecer-se o Correio diario a esta Villa.

$55 \quad$ Deus Guarde a Vossa Excellencia

Illustrissimo e Excellentismo Senhor Barão de Jaguára

Muitissimo Dignissimo Presidente desta Provincia

Joaõ Aguiar de Barros

Joaquim Floriano de Toledo

60 Jose Mathias de Almeida Barboza

Francisco Silverio de Araujo

65 
127

Documento 08: Parecer do administrador dos Correios de São Paulo referente pedido de licença de funcionário, datada de 04 de outubro de 1889.

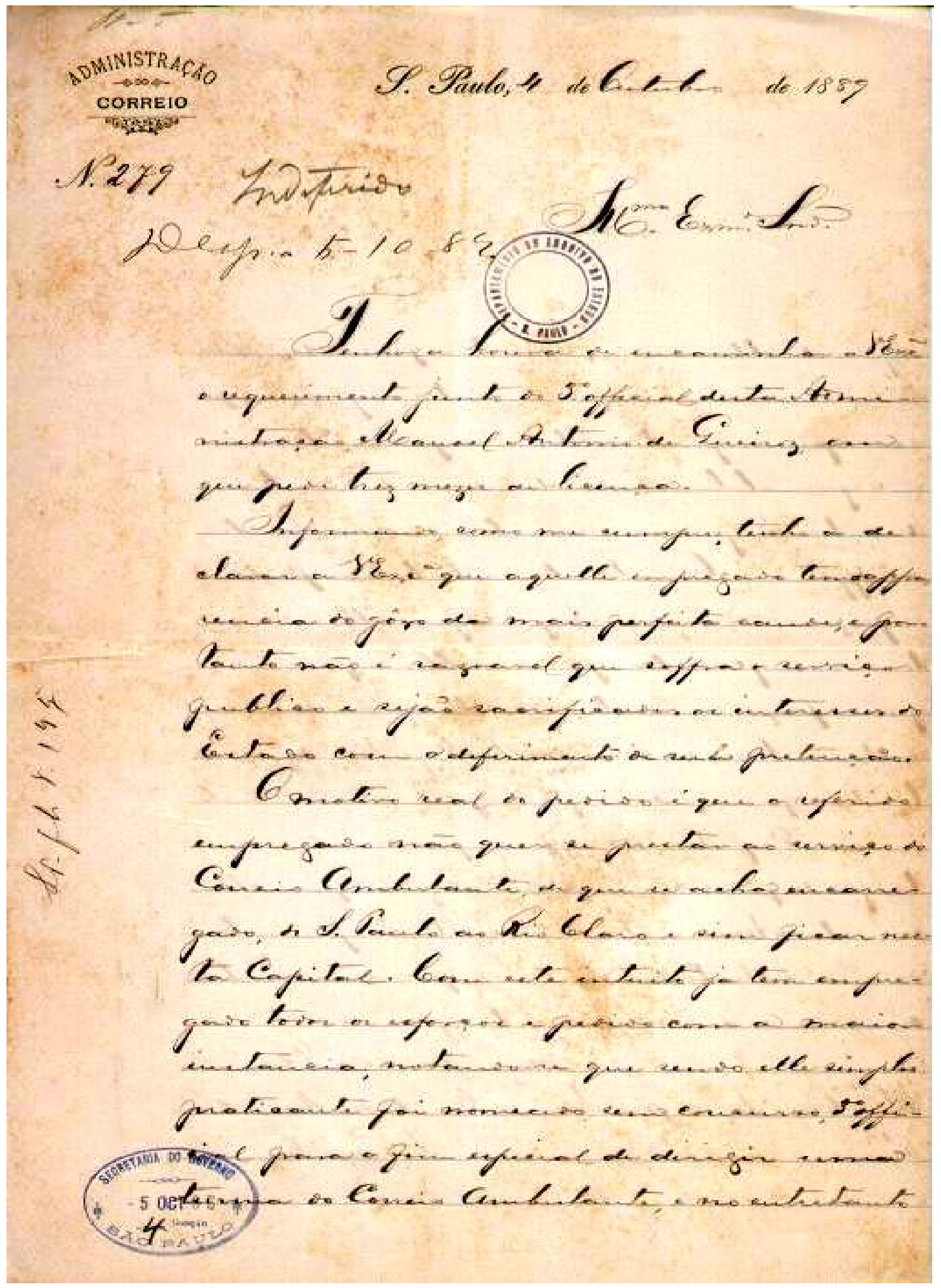


$\|1 \mathrm{r} .\|^{38}$ São Paulo, 4 de Outubro de 1889.

$<$ Numero 279> ${ }^{39}$

Illustrissimo Excelentissimo Senhor ${ }^{40}$

Tenho a honra de encaminhar a Vossa Excelencia

5 o requerimento junto do Terceiro official desta Admi. nistração, Manoel Antonio de Queiroz em que pede trez mezes de licença.

Informamos, como me cumpre, tenho a declarar a Vossa Excelencia que aquelle empregado tem appa rencia do gôzo da mais perfeita saude, e portanto não é razoavel que soffra o serviço publico e sejaõ sacrificados os interesses do Estado com o deferimento de sua pretenção.

O motivo real do pedido é que o referido empregado não quer sr prestar ao serviço do Correio Ambulante, de que se acha encarregado, de São Paulo ao Rio Claro e sim ficar nesta Capital. Com este intuito já tem empregado todo os esforços e pedido com a maior instancia, notando-se que sendo elle simples praticante foi nomeado sem concurso, Terceiro official para o fim especial de dirigir uma ${ }^{41}$ turma do Correio Ambulante, e no entretanto

\footnotetext{
${ }^{38}$ Timbre da Administração do Correio, situado no canto superior esquerdo do documento.

39 Informação tardia de terceiro escrita a lápis entre a data e o tratamento formal, que informa: Indeferido Despacho 5-10-89.

${ }^{40}$ Carimbo circular do Arquivo do Estado de São Paulo, aposto entre o tratamento e o início do documento.

${ }^{41}$ Carimbo oval da Secretaria de Governo, datado de 5 de outubro de 1889, aposto no canto inferior esquerdo do documento.
} 
129

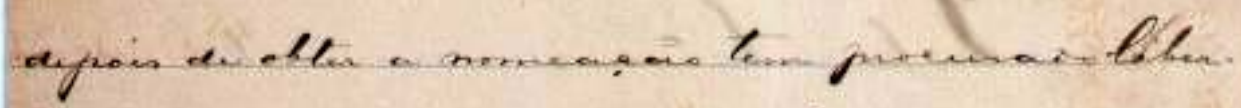

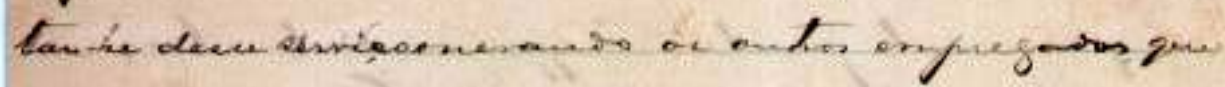

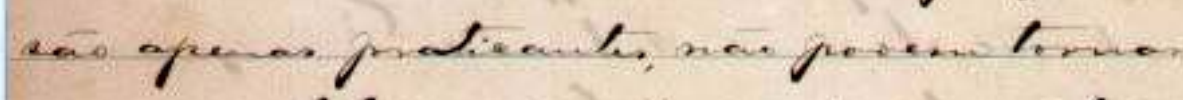

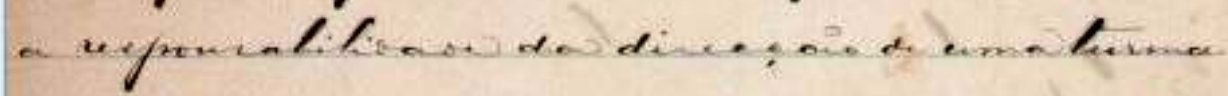

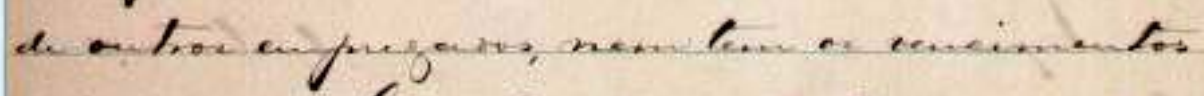

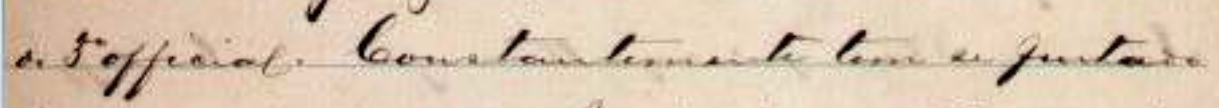

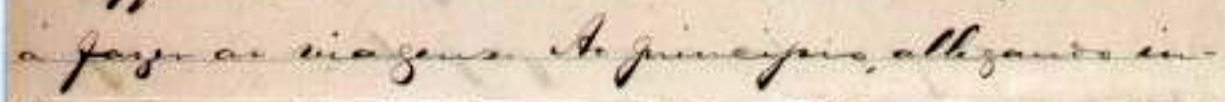

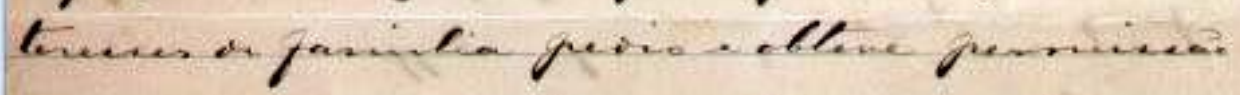

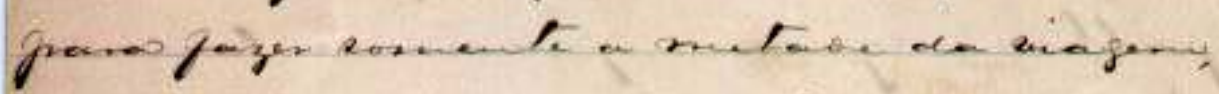

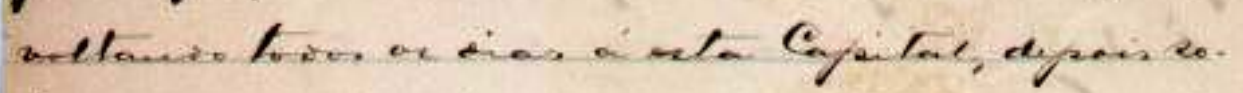

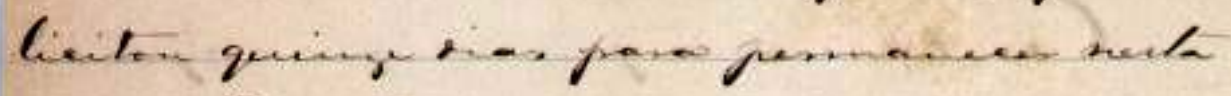

meme Coptal, ato finenpor mait mais

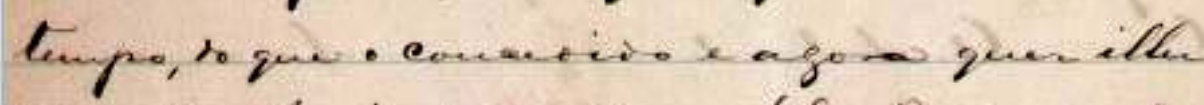

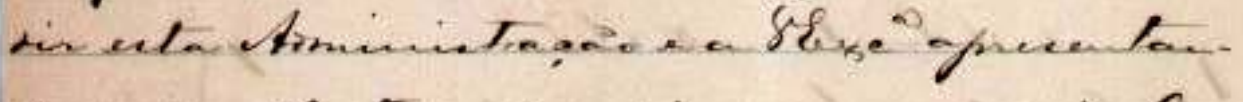

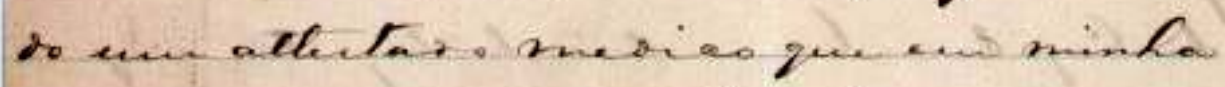

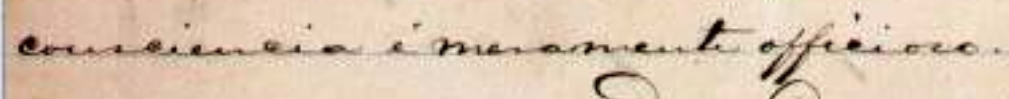

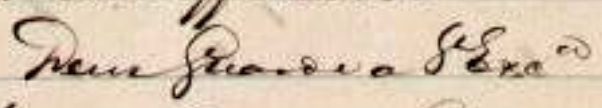

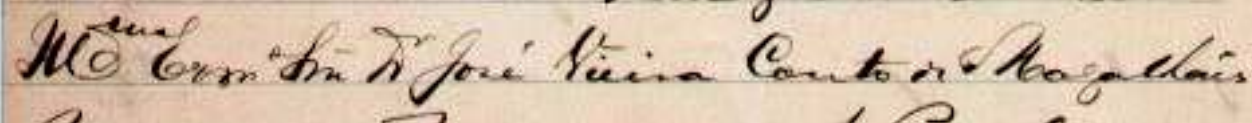

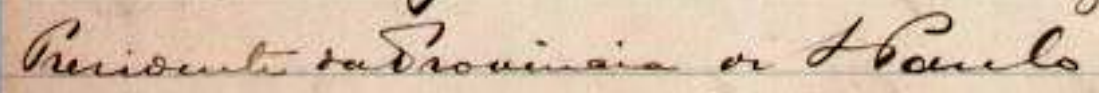

Qastimantarartor

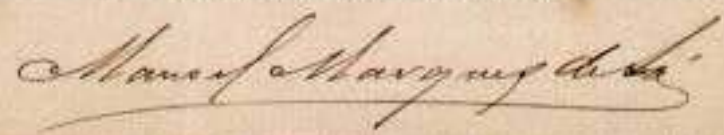


||1v.|| depois de obter a nomeação tem procurado liber-

tar-se desse serviço onerando os outros empregados que

são apenas praticantes, não podem tomar

a responsabilidade da direcção de uma turma

de outros empregados, nem tem os vencimentos

de terceiro official. Constantemente tem se furtado

${ }^{42}$ á fazer as viagens. Ao principio, allegando in-

teresses de familia pedio e obteve permissão

para fazer somente a metade da viagem,

voltando todos os dias á esta Capital, depois so-

licitou quinze dias para permanecer nesta

35

mesma Capital, onde ficou por muito mais

tempo, do que o concedido e agora quer illu-

dir esta Administração e a Vossa Excellencia apresentan-

do um attestado medico que em minha

consciencia é meramente officioso.

Deus Guarde a Vossa Excellencia

Illustrissimo Excellentissimo Senhor Doutor José Vieira Couto de Magalhaẽs

Presidente da Provincia de São Paulo

O Administrador

\section{Manoel Marquez de Sá}


131

I

Documento 09: Solicitação de ampliação de linha de transporte de cartas, entre Botucatu e São Manoel por meio de estrada de ferro Sorocabana, datado de 15 de maio de 1889.

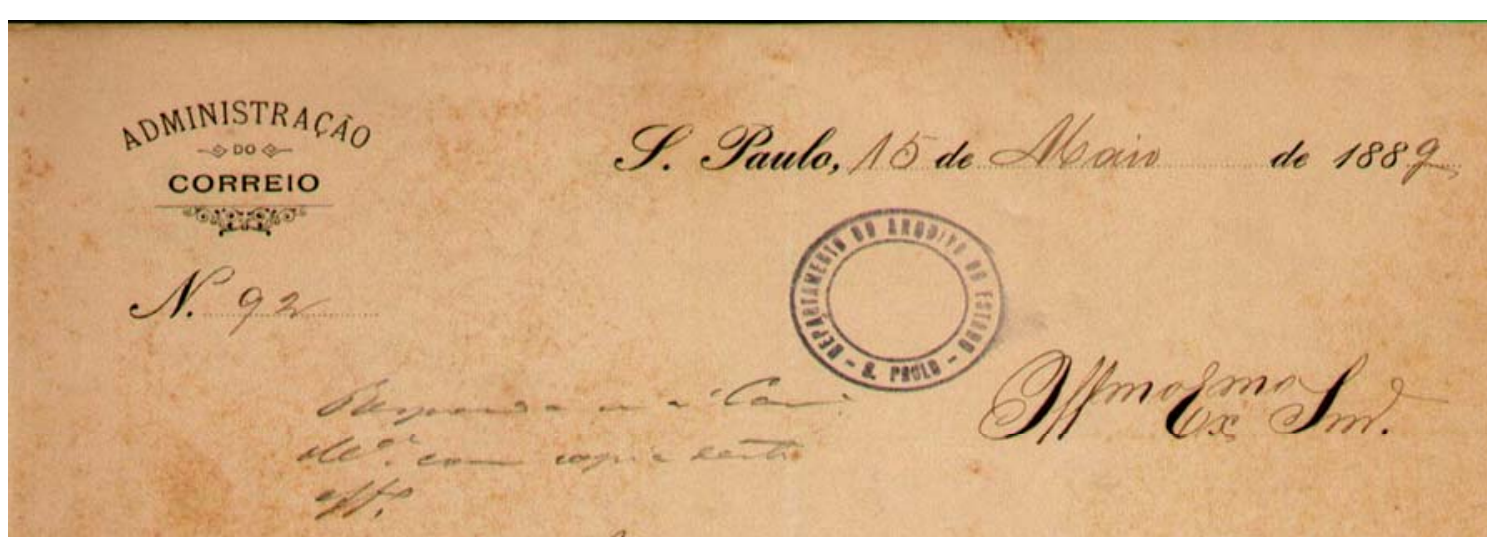

Livista darepesicar fertayeles mon -

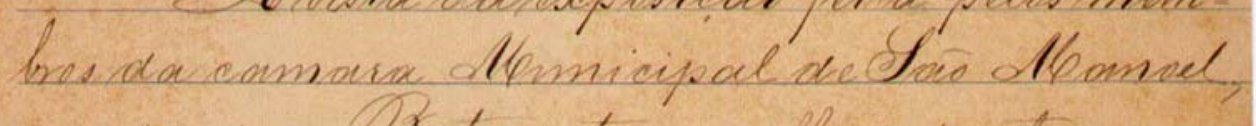

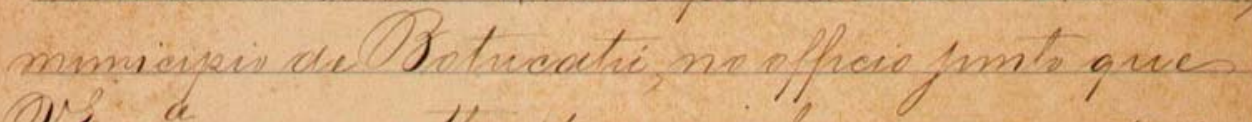

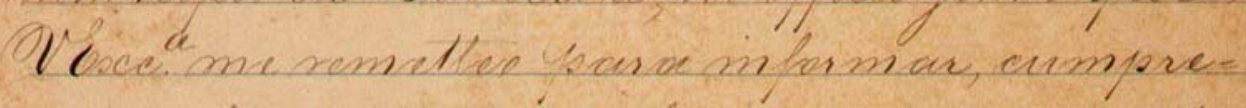
me dedar ar quexim nelaceac ac erescimento

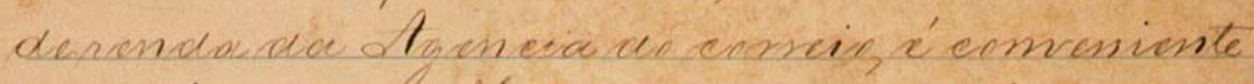
ar mleresse ynthes, quesga cotablecider v.

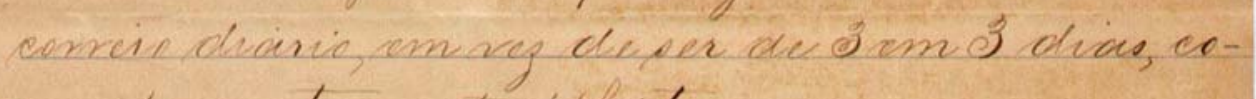
mis pregentominte cite.

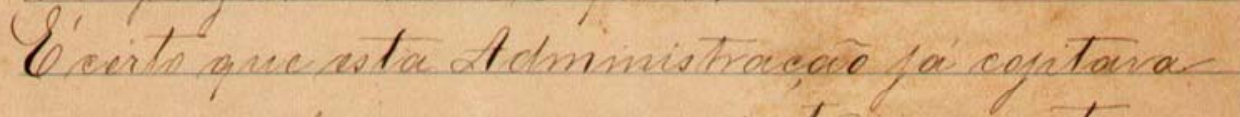
nessa mindanca, esperander tain somente a peprtimidade, ane ci ponen acala de dar-

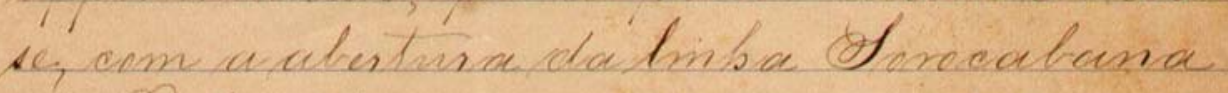
aliogetucatí.

Geondrecar dous malas de corscis, des modo lombrade fiela cam ara dlemicipal, alomdo. mands a cemm micaear com Sotucatu; que

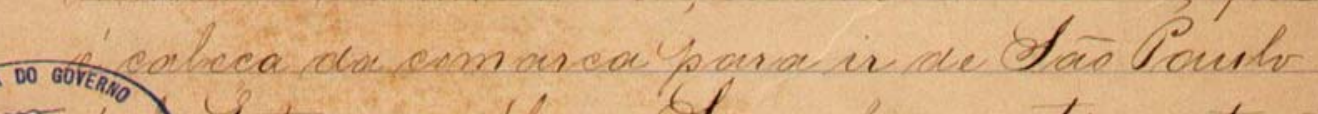

STMIM MAI 8 \&
4 S Socsio

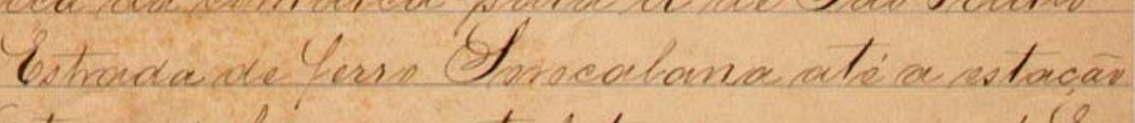

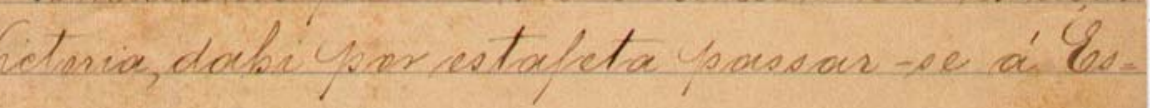


"1r.|| ${ }^{43}$ São Paulo, 15 de Maio de 1889.

$<$ Numero $92>{ }^{44}$

${ }^{45}$ Illustrissimo Excellentissimo Senhor

Á vista da exposição feita pelos mem-

5 bros da camara Municipal de São Manoel, municipio de Botucatú, no officio junto que

Vossa Excellencia me remetteo para informar, cumpre-

me declarar que em relaçaõ ao crescimento

${ }^{46}$ de renda da Agencia de correio, é conveniente

ao interesse publico, que seja estabelecido o

correio diario, em vez de ser de 3 em 3 dias, co-

mo prezentemente é feito.

É certo que esta Administração já cojitava

nessa mudança, esperando tão somente a

opportunidade, que á pouco acaba de dar-

se, com a abertura da linha Sorocabana

ate Botucatú.

A conducçaõ das malas do correio, de modo

lembrado pela câmara Municipal, abando=

nando a communicaçaõ com Botucatú, que

é cabeça da comarca para ir de São Paulo

pela Estrada de ferro Sorocabana até a estação

${ }^{47}$ de Victoria, dahi por estafeta passar se á Es=

\footnotetext{
43 Timbre da Administração dos Correios

${ }^{44}$ Carimbo circular do Arquivo do Estado De São Paulo localizado entre a data e o inicio do texto do documento à margem direita do mesmo.

${ }^{45}$ Informação tardia de terceiros, localizada ao lado esquerdo da evocação, com os dizeres: Resposta ao Correio/ Administrador com copia deste/ officio

${ }^{46}$ Informação de terceiros, localizada na margem esquerda do documento, com os dizeres: Por cópia a

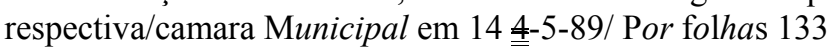

${ }^{47}$ Carimbo da Secretaria do Governo, em formato oval, datado de 16 de maio de 1889, aposto no canto inferior esquerdo do documento.
} 
133

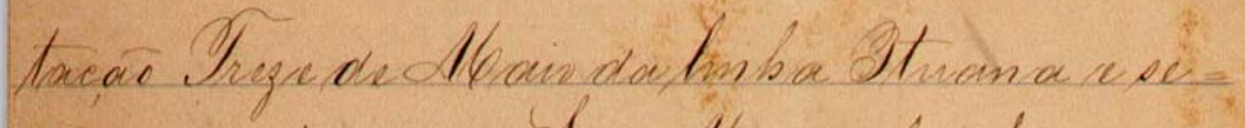
amir deponis youra dow Lleannd, alum de dispendiesa mare estar esta dedmimistrasar antmigada, soria am da de Ysonca seguromea.

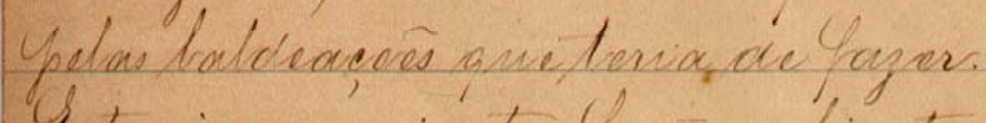

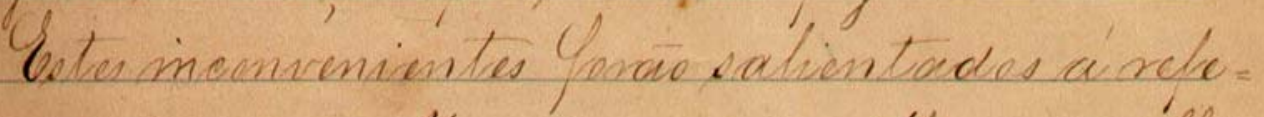
nida comora allemicijsal em attencieso offion, an qual caquella comoua, nas aprecian = de, come deviria, dis ceme nesposta de cesta Administracar a poner Ysolida devoluear de mesmir sfrew.

Asom, desde que se cucha aberto strafego da

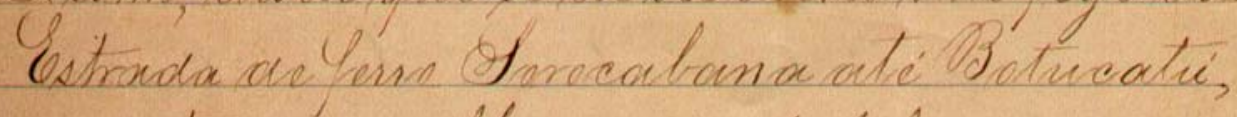

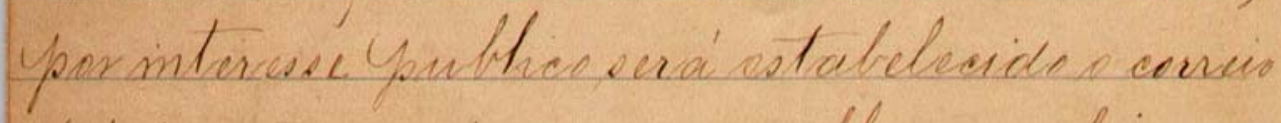

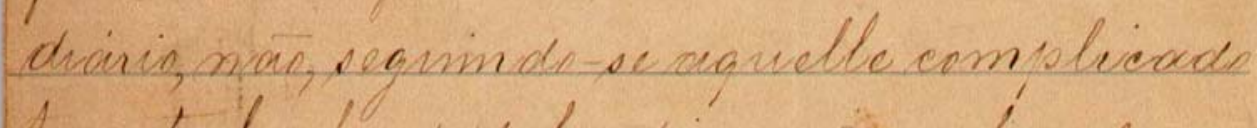

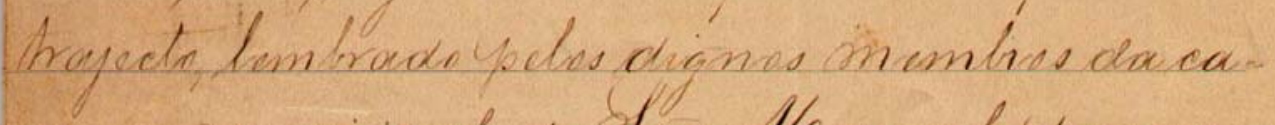
mana municipal de Slav Lleanod, yerem im Ypda Estrada de Curo G/orocaboma ate

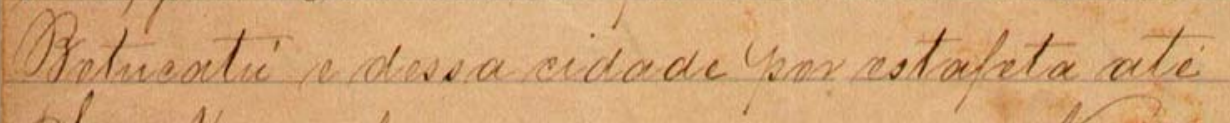

dan Allemnel. 
||1v.| tação Treze de Maio da linha Ituana e se=

guir depois para São Manoel, alem de

dispendiosa e não estar esta Administraçaõ

autorizada, seria ainda de pouca segurança

pelas baldeaçoẽs que teria de fazer.

Estes incovenientes forão salientados á refe=

30

rida camara Municipal em attencioso offi-

cio, ao qual aquella camara, não aprecian=

do como devêra, dêo como resposta à esta

Administração a pouco polida devoluçaõ do

mesmo officio.

35

Assim, desde que se acha aberto o trafego da

Estrada de ferro Sorocabana at-é Botucatú,

por interesse publico será estabelecido o correio

diario, não, seguindo-se aquelle complicado

trajecto, lembrado pelos dignos membros da ca-

40

mara municipal de São Manoel, porem

sim, pela Estrada de ferro Sorocabana até

Botucatú e dessa cidade por estafeta até

São Manoel. [Espaço] Nesta

45

50

55

60 
135

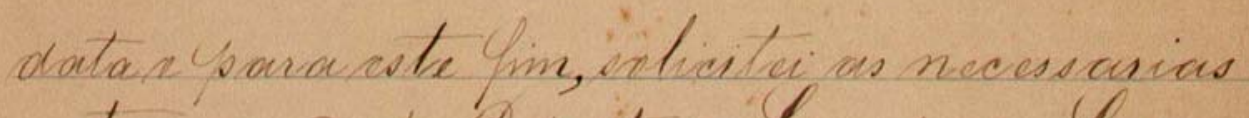

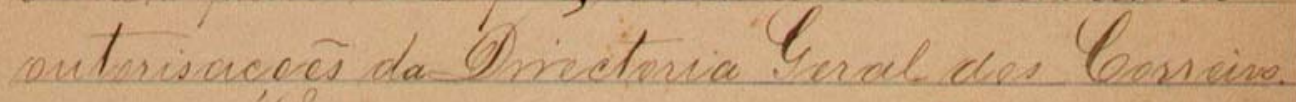
'Cotas par as imfrimaceñes que me

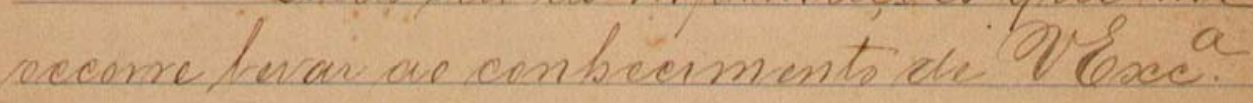

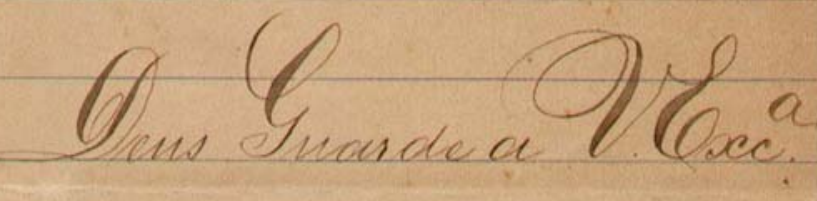

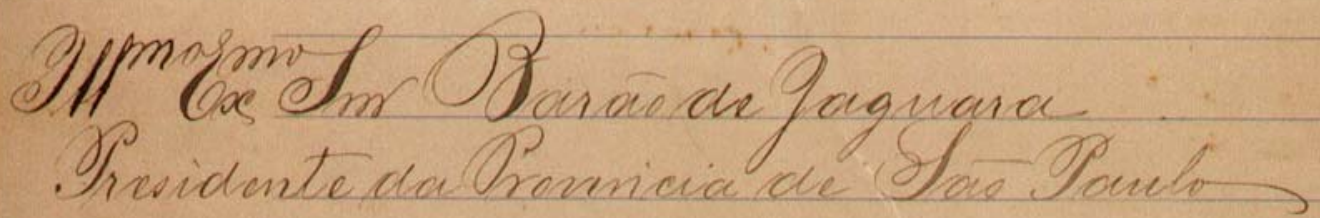

Octiminuthas

cllawalothymy atf

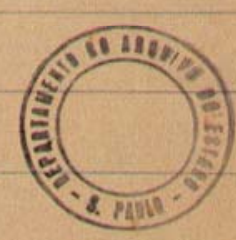


||2r.||data e para este fim, solicitei as necessarias

45 autorisaçoẽs da Directoria Geral dos Correios.

Estas são as informaçoẽs que me ocorre levar ao conhecimento de Vossa Excellencia.

Deus Guarde a Vossa Excellencia

Illustrissimo Excellentissimo Senhor Barão de Jaguara

50 Presidente da Provincia de São Paulo

O Administrador

Manoel Marquez de Sa ${ }^{48}$

55

60

65

70

75

80

85

${ }^{48}$ Carimbo circular do Arquivo do Estado de São Paulo abaixo da assinatura. 
137

Documento 10: Resposta a solicitação de revisão de categoria da agencia São Manoel do Paraíso, datada de 14 de janeiro de 1890.

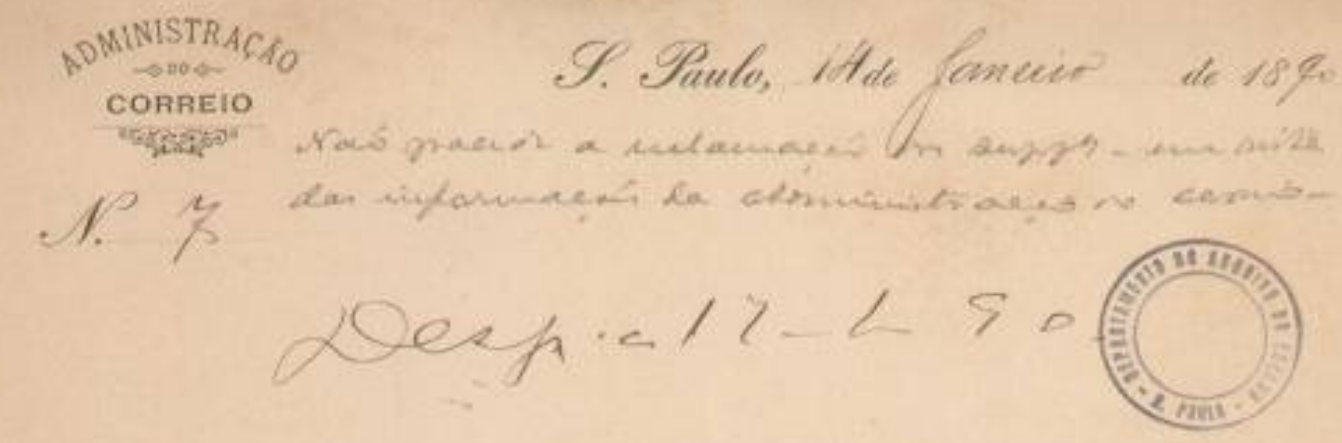

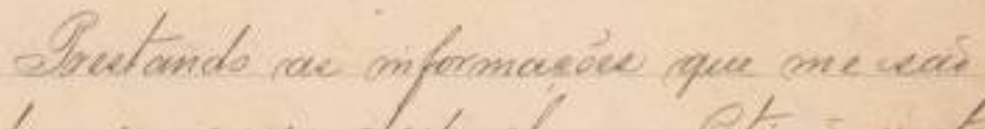
esequidas en maees dectioneles na reticas punta

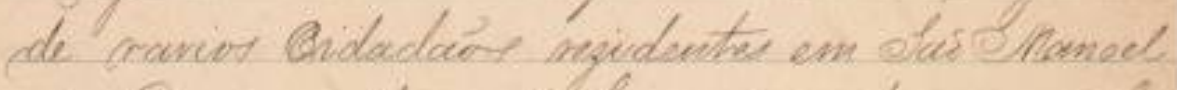

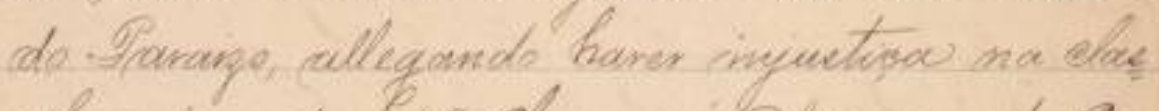
ufreares de Pya Arue a OAgeneina do Bors

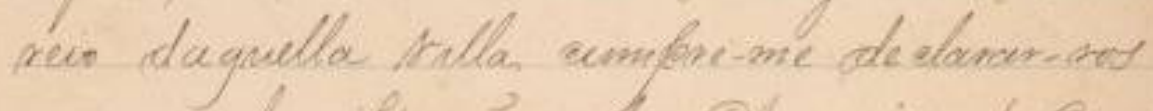

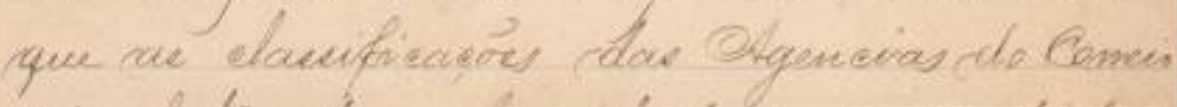
vas futas de confurandade com ae cluefors eoues do Regulamento petal de 26 de Harea cle 1885 .

Zara que nma Mogenciai eya

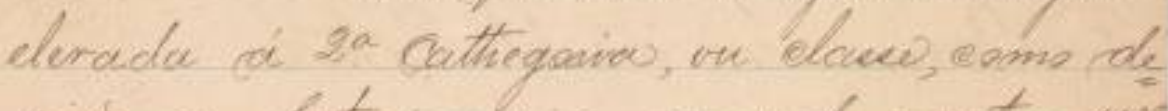

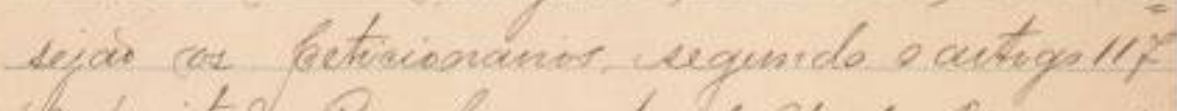
it on citach Requameuts de 26 de Niparee de 1858 "'metér gque a seve menda commal

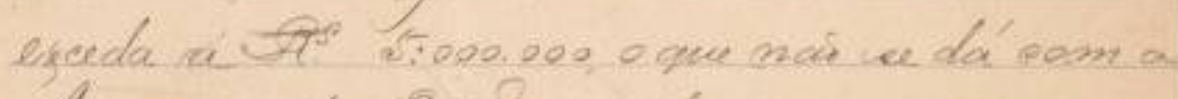
- Agencia de elas monod que me amo an therred ena de pegriena rexda e comente

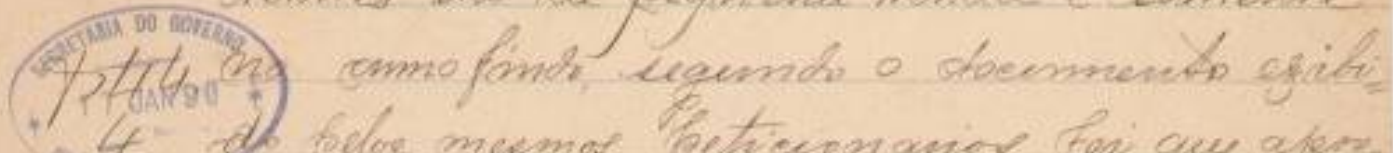

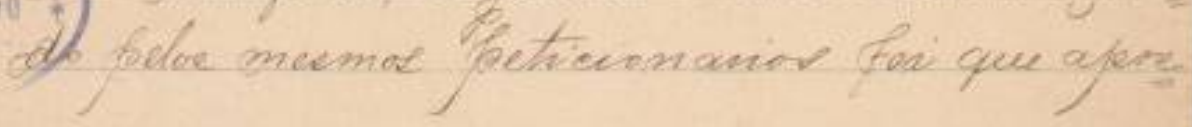


\|1r. $\|^{49}$ São Paulo, 14 de janeiro de 1890.

${ }^{50}<$ Numero $07>$

51 Prestando as informações que me são

exigidas em vosso despacho na Petição junto

5 de varios Cidadaõs rezidentes em São Manoel

do Paraizo, allegando haver injustiça na clas

sificação de quarta Classe á Agencia de Cor=

reio daquella villa cumpre-me esclarecer-vos

que as classificações das Agencias de Correios

10 são feitas de conformidade com as disposi

ções do Regulamento Postal de 26 de Março

de 1888 .

Para que uma Agencia seja

elevada á segunda Cathegoria, ou classe, como de

15 sejão os peticionarios, segundo o artigo 117

paragrafo do citado Regulamento de 26 de Março de

1888 é mistér que as sua renda annual

exceda á 5.000.000 Reis, o que não se dá com a

Agencia de São Manoel que nos annos an

20 teriores era de pequena renda e somente

no anno findo, segundo o documento exibi

${ }^{52}$ do pelos mesmos peticionarios foi que apre

\footnotetext{
${ }^{49}$ Timbre da administração do Correios.

${ }^{50}$ Informação tardia de terceiros, situada entre a datação e o corpo do ofício, com os seguintes dizeres: Não apreciou a reclamação dos Superintendentes/ das informações da administração do Correio

${ }^{51}$ Interferência tardia de terceiros, feita a lápis entre a datação e o início do documento: Despacho 17-1-90. Ao lado direito da informação há um carimbo circular do Arquivo do Estado de São Paulo.

${ }^{52}$ Carimbo oval da Secretaria do Governo. Dentro do carimbo há marcações em lápis com os dizeres: Página 44; 4ª Seção
} 


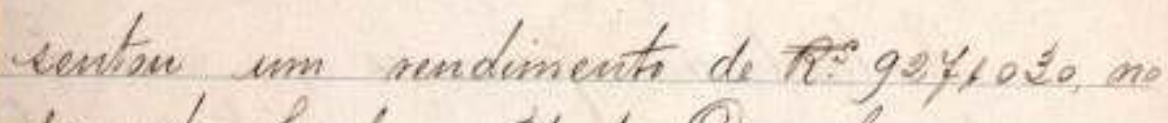
Lomeatie findt a 31 de Tegembr On mita dae diebovereses teques nas bode pon tanit porturder-ive que a Prgen

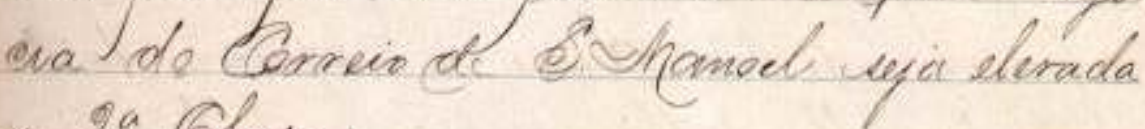
ra 2a. Grave.

\section{Saude eptratermidade}

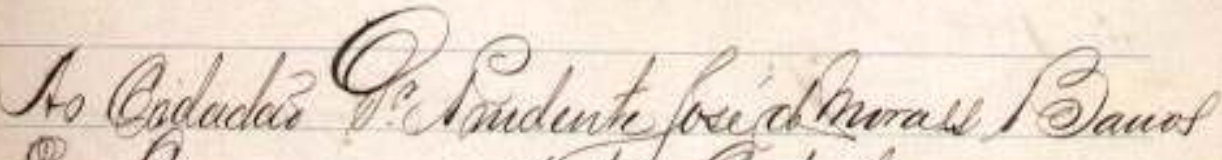
Q. Qorennaror verty) Ertado
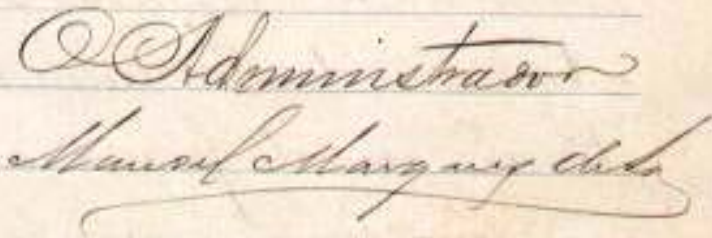
||1v.| $\quad$ sentou um rendimento de 9271030 Reis, no semestre findo a 31 de Dezembro.

25

Em vista das disposições legaes

não póde por tanto pretender-se que a Agen

cia de Correio de São Manuel seja elevada

a Segunda Classe.

Saude e Fraternidade

30 Ao Cidadão Presidente Prudente José de Moraes Barros

Dignissimo Governador d'este Estado

OAdministrador

$\underline{\text { Manoel Marquez de Sa }}$ 


\section{Considerações finais}

A partir das finalidades do trabalho filológico, estabelecemos relação com sua função transcendente para buscarmos nos manuscritos da Administração Geral dos Correios parte da história dos meios de comunicação existentes no Brasil Império. O resgate histórico dos procedimentos administrativos de um órgão governamental, e, ainda hoje, público, auxiliados pela edição dos documentos, auxiliarão em estudos posteriores, como instrumento para pesquisas de cunho histórico e linguístico. Quanto à habilidade dos escribas, apoiamo-nos na análise paleográfica, em decretos postais e estudos sociais para verificar o conhecimento de escrita que os funcionários de correios, da época, possuíam. Esses assuntos foram tratados na primeira parte do trabalho, reservado ao levantamento social e a análise codicológica. Essa última, de grande importância, para demonstrar o aspecto físico da documentação e seu estado original.

A segunda parte do trabalho inicia-se pela análise paleográfica. Como o corpus, em sua totalidade, é apógrafo não nos apoiamos nos responsáveis pela assinatura, mas sim nos indícios históricos acerca das atribuições e escolaridade dos escribas, bem como os procedimentos, aos quais se apoiavam para a elaboração dos ofícios. Esta última informação foi necessária para analisar os hábitos de escrita social da época, visando captar dados concretos para a análise lingüística. Realizamos também a comparação entre as assinaturas e corpo de texto para comprovarmos tal apografia, além da verificação da incidência de um mesmo punho em mais de um documentos. Tais análises mostram-se muito importantes para os passos seguintes da pesquisa e para um estudo lingüístico fiel.

A análise paleográfica também foi responsável pelo levantamento quantitativo e qualitativo dos diacríticos, permitindo análise posterior dos dados. Tais informações foram essenciais para a elaboração de uma edição confiável e da análise de todas as palavras que receberam o diacrítico agudo.

Com base nos levantamentos paleográficos, partimos nessa fase centralizando nossas análises no diacrítico agudo. Apoiando-nos em gramáticos e dicionaristas do século XIX, buscamos perspectivas explicar o uso do referido sinal. Foi por meio do resgate etimológico que traçamos o perfil de cada vocábulo, procurando respostas ao emprego do acento agudo, 
numa época em que as gramáticas mencionavam a intensidade das vogais e das sílabas, sem que houvesse a sistematização para o uso do diacrítico.

Regras, como as que conhecemos atualmente, para o emprego de um ou outro sinal de acentuação não foram encontradas nas gramáticas do século XIX. Salvo Julio Ribeiro (1881) em sua Grammatica Portugueza faz breve menção ao emprego dos acentos. Verificamos, ainda, que ao final do século XIX o acento circunflexo já era utilizado para indicar o "fechamento da voz", no entanto, no início do mesmo século, Antonio de Moraes Silva (1802), em sua Epitome da Grammatica Portugueza faz referência ao acento agudo ('), grave ( ) e nasal $(\sim)$, afirmando que o "accento circumflexo não o temos", pois a concepção do referido sinal diacrítico remetia ao uso latino, língua em que havia o "alçamento e abaixamento de voz". Jeronymo Soares Barboza (1862), em meados do XIX, em sua Grammatica Philosophica da Lingua Portugueza, aplica ao uso dos acentos os mesmos preceitos latinos, cujo uso era prosódico. Diante disso optamos pela análise do trajeto etimologia da palavra, com vistas a resgatar o emprego da intensidade nos diferentes períodos da língua, uma vez que a prosódia era um dos fatores para se aplicar o sinal.

Verificamos que o emprego do acento agudo, nos verbos, deu-se, em sua totalidade, sobre a última sílaba, que se originou do verbo auxiliar habere, responsável pela formação do futuro condicional no latim vulgar. Os processos de assimilação da língua resultaram na tonicidade da vogal final que recebeu o acento agudo. Nos processos de mudança da língua e nos tempos analisados não houve a mudança de intensidade entre as sílabas e as sílabas longas mantiveram seu timbre no português moderno. Percebemos que a aplicabilidade do agudo nos verbos resultou, não somente, na verificação de heranças lingüísticas quanto à intensidade vocálica, mas também na aplicação dos hábitos da língua falada. Tal conclusão é possível pela verificação do verbo conjugado condúz, presente em documento de 1833, que explicita a intensidade da última sílaba, confirmada pela raiz latina, mas divergentee do emprego do acento na época, pois o referido verbo não era acentuado. Contrário a esse exemplo o verbo $f a ́ z$, encontrado em manuscrito de 1879 era, realmente, acentuado no início do século. Tal uso do agudo não deixa de demonstrar uma identificação com a língua falada, mas aponta para a identificação da sílaba tônica. Tais características devem ser consideradas, no entanto, com ressalvas, pois os verbos presentes estão no presente do indicativo e futuro do presente.

Como nos verbos o mesmo processo foi verificado nas demais palavras que receberam o acento agudo. 
Outro fator encontrado do documento, que aponta para o emprego do acento agudo, é inexistência do uso da crase para demonstrar a contração e utilização do agudo em substituição do acento grave na crase. A junção de preposição e artigo era demonstrada com o agudo, em ocorrências como em á despeza, á vista, á agencia. A contração ou união de vozes semelhantes, era compreendida como intensificação da sílaba. Além disso, o processo de assimilação em vocábulos que apresentam vogais iguais dava-se com o acento agudo.

A partir do início do século XX, Gonçalves Viana (1904) em sua Ortografia Nacional passa a traçar regras para o emprego dos sinais diacríticos, atribuindo a cada acento uma utilização específica, uniformizando o uso dos acentos, mas, ainda assim aplicando as regras fonológicas de timbre e tonicidade para marcar a intensidade das sílabas.

Concluímos que a intensidade existente no latim clássico manteve-se como timbre no latim vulgar e no português moderno e as mudanças recorrentes da língua proporcionaram o uso de acentos gráficos nasais sílabas que sofriam uma maior intensidade, mas não em sua totalidade.

Os levantamentos realizados contribuirão para estudos futuros acerca da aplicabilidade de todos os diacríticos, uma vez que atualmente poucos trabalhos abordam o percurso filológico do emprego desses sinais. Estarão à disposição para complementação de estudos relacionados aos diacríticos, em especial, o circunflexo, cedilha, apóstrofo e til, não menos importantes, mas não aprofundados nesse trabalho. 


\section{Referências Bibliográficas}

ACIOLI, V.L.C A escrita no Brasil colônia: um guia para a leitura de documentos manuscritos. Recife: Editora Massangana, 1994.

ALMEIDA, J. R. P. Instrução pública no Brasil (1500-1889): história e legislação. São Paulo: Educ, 2000

AZEVEDO, A. Apontamentos históricos, geográficos, biográficos, estatísticos e noticiosos da província de São Paulo. S. Paulo, Livraria Martins Fonte: 1952

BACELLAR, B. L. M. Grammatica philosophica da lingua portugueza. Lisboa, 1783. P. 11-13

BARBOSA, J. S. Grammatica philosophuca da língua portugueza ou princípios da grammatca geral applicados á nossa linguagem. $3^{\text {a }}$ edição. Lisboa: Tipografia da academia, 1862.

BARROS NETO, J. P. Administração pública no Brasil: uma breve história dos Correios. S. Paulo: Editora Annablume, 2002. Cap. 1, p. 7-50.

BELLOTO, H. L Como fazer análise diplomática e análise tipológica de documento de arquivo. São Paulo: Arquivo do Estado e Imprensa Oficial do Estado, 2002. 120 p.

Autoridade e conflito no Brasil colonial: o governo de Morgado de Mateus em São Pualo (1765-1776). S. Paulo: Alameda Casa Editorial, 2007. p. 201-214

BERWANGER, A R \& LEAL, J. E. F Noções de paleografia e de diplomática. Santa Maria: Editora UFSM, 2008

BLUTEAU, R. Vocabulário portuguez \& latino. Coimbra: Colégio das artes da Companhia de Jesus, 1712

BRASIL. Lei 40 de 03 de outubro de 1834. Dá regimento aos presidentes de província e extingue o conselho da presidência. Disponível em http://www.camara.gov.br/Internet/InfDoc/conteudo/colecoes/Legislacao/Legimp-19/Legimp-

19 7.pdf. Acesso em: 21. Jun. 2010.

BRASIL. Constituição do Império do Brasil (25 de março de 1824). Dispõe sobre a constituição política do império do Brasil em 1824. Disponível em $<$ http://www.planalto.gov.br/ccivil_03/Constituicao/Constituiçao24.htm>. Acesso em 02.Jun. 2010

BRASIL. Decreto $n^{0}$ 1930, de 26 de abril de 1857. Aprova o Regulamento para a fiscalização da segurança, conservação e policia das estradas de ferro, em virtude do $\S 14$ do Art. $1^{\circ}$ do Decreto $\mathrm{n}^{\mathrm{o}} 641$ de 26 de Junho de 1852. Disponível em: $<$ http://www.planalto.gov.br/ccivil_03/decreto/1851-1899/D1930.htm>. Acesso em 02. Jun. 2010

CABRAL, L. M. Selos, moedas e poder: o estado imperial brasileiro e seus símbolos. Rio de Janeiro: Apicuri. 2009. 190 p.

CARDERA, E. O essencial sobre a história do português. Lisboa: Caminho, 2006. 
COUTINHO, I. L Gramática histórica. Rio de Janeiro: Ao livro técnico: 1998. 360 p.

CUERVO, R. F. Disquiciones sobre la filologia castellana. Buenos Aires, El Ateneo. p. 200 $-210$.

CUNHA, A. G Dicionário histórico das palavras portuguesas de origem tupi. São Paulo: Ed. UnB, 1999

CUNHA, A. G. Dicionário etimológico da língua portuguesa. Rio de Janeiro: Lexikon Editora. 1986

FARIA, E. Fonética histórica do latim. $2{ }^{\text {a }}$ Edição. Rio de Janeiro:. Livraria Academica, 1937. P.134-160 .

FILHO, L. M. F de; VIDAL, D. G. Os tempos e os espaços escolares no processo de institucionalização da escola no Brasil in Revista Brasileira de Educação. Rio de Janeiro, n. 14, p. 19-34, maio/ago. de 2000.

FONSECA, M. L. T. F Selos Postais in Revista COFI: Correios filatélico, ano XXX, $\mathrm{n}^{\mathrm{o}}$ 10, abril, maio e junho. Brasília: Empresa Brasileira de Correios e Telégrafos: 2008. p. 24 -25

GONÇALVES, R. Luzes e Sombras sobre a colônia: educação e casamento na São Paulo do século XVIII. São Paulo: Humanitas, 1996

HIGOUNET, C História concisa da escrita. São Paulo: Editora Parábola, 2004.

HOUAISS, A. Grande dicionário Houaiss da língua portuguesa. Rio de Janeiro: Objetiva, 2008

LEAO, D. $\mathrm{N}$ do Orthographia da lingoa portuguesa : obra vtil \& necessaria assi pera bem screuer a lingoa Hespanhol como a Latina \& quaesquer outras que da Latina teem origem. Lisboa, 1576. Disponível em: http://purl.pt/index/geral/aut/PT/47390.html. Acesso em 20. Mar. 2010.

LISBOA. Departamento de História da Universidade de Nova Lisboa. Alvará de 20 de janeiro de 1798. In: Ius Lusitaniae. Lisboa, 2008. Disponível em: $<$ http://iuslusitaniae.fcsh.unl.pt/verlivro.php?id_parte=110\&id_obra=73\&pagina=744. $>$ Acesso em 05. Jul. 2008.

MARCÍLIO, M. L. História da escola em São Paulo e no Brasil. São Paulo: Imprensa Oficial. 2005. p. 58-89.

MARQUILHAS, R. A faculdade das letras: leitura e escrita em Portugal no século XVII. Bragança Paulista: EDUSF, 2003

MARTINS, W. A palavra escrita: história do livro, da imprensa e da biblioteca. S. Paulo, Editora Ática: 1996

MATTOS e SILVA, R. V. O português arcaico: fonologia, morfologia e sintaxe.São Paulo: Contexto. 2006. p. 49-145

MAURER, T. H. Gramática do latim vulgar. Rio de Janeiro: Livraria acadêmica. 1959.

MEGALE, H. Por minha letra e sinal: documentos de ouro do século XVII. São Paulo: Fapesp, 2007

MENDES, U. D. Noções de paleografia. S. Paulo: Editora do Arquivo do Estado de S. Paulo, 2008. $104 \mathrm{p}$. 
SILVA, A. M. Epitome da Grammatica da língua portugueza. Lisboa: Simao Tadeu Ferreira. 1806 . Diccionário da língua portugueza. $2^{\mathrm{a}}$ edição. Lisboa: Typographia Lacerdina, 1813

NOBILING, O. As vogais nasais em português I in Revista de Estudos Semânticos. Coleção Littera. Org: Marques, Maria Helena Duarte. Rio de Janeiro: Grifo. 1976.

NUNES, J. J. Compendio de gramática histórica portuguesa. Lisboa: Livraria Clássica Editora, 1945. p. 188-190.

OLIVEIRA, F. Grammatica da lingoagem Portuguesa. $3^{\text {a }}$ Edição. Lisboa. 1936. p. 55-60

PAULIS, E. Vale do Paraiba: trilha e falha in MEGALE, H (org) Filologia Bandeirante. S. Paulo: Editora Fapesp, 2000. p. 93-106.

RIBEIRO JUNIOR, G e BAYLONGUE, J. R. Aspectos da história postal do rio Tietê. Catálogo Exposição história postal de S. Paulo, 1998. Disponível em http://www.fefiesp.com.br/artigo3.htm. Acesso em 03.set.2008

RIBEIRO, J. Grammatica portugueza. $1^{\text {a }}$ Edição. Rio de Janeiro. Francisco Alves. 1881. p. 2-40 e 215-180.

RIBEIRO, M. L. S. História da educação brasileira: a organização escolar . São Paulo: Editora Cortez, 1987. 75p.

ROQUETE, J. I. O Novo secretário português. Paris: Vª J. P. Aillaud, Monlon e Cª 1860

ROSARIO, I. de O. Três séculos e meio da história postal brasileira (1500 - 1843). Rio de Janeiro: Empresa Brasileira de Correios e Telégrafos, 1993

SÃO PAUlO (Município) Decreto de 5 de março de 1828. Revista do Archivo Municipal de São Paulo. S. Paulo, volume XV, ano II, p. 425-453, 1935

SILVEIRA, M. I. M. Análise de gênero textual: concepção sócio-retorica. Maceió: EDUFAL, 2005. p.119-200

SPINA, S. Introdução à edótica (Crítica textual). São Paulo: Cultrix. 1977

VIANA, A. R, G. Simplificação e uniformização das ortografias portuguesas. Lisboa:Livraria editora viúva Tavares Cardoso, 1904-

WILLIANS, E. B. Do latim ao português. Rio de Janeiro: Tempo Universitário. 1973. p. 15 a 110. 